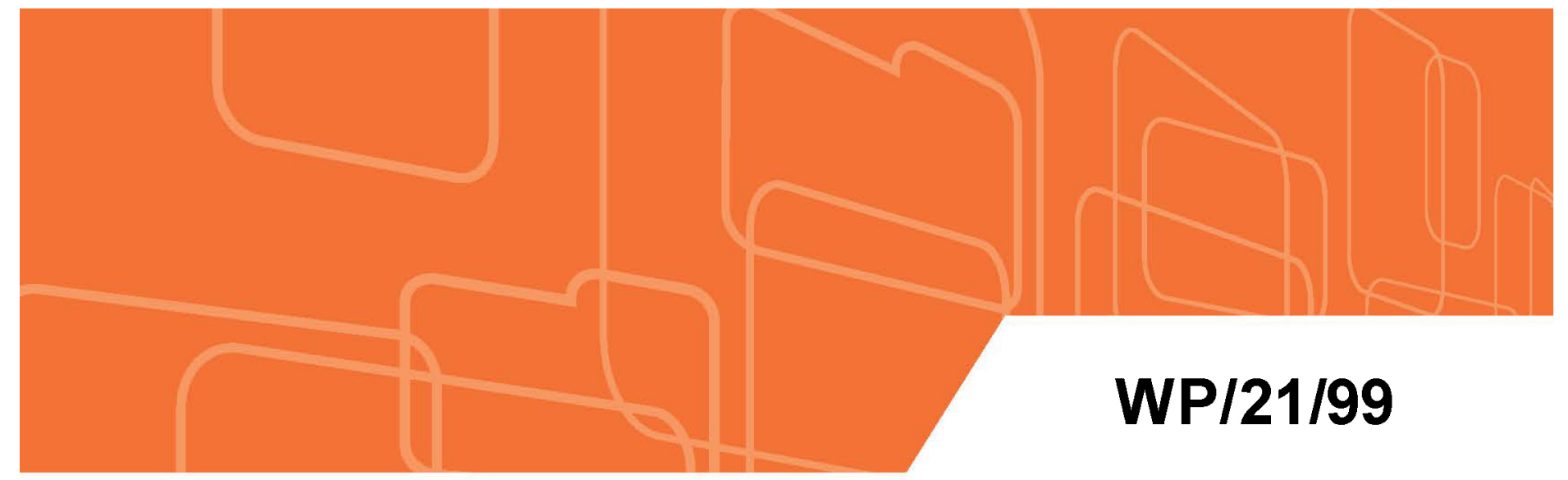

\title{
Smart Containment: Lessons from Countries with Past Experience
}

by Alexandra Fotiou and Andresa Lagerborg

IMF Working Papers describe research in progress by the author(s) and are published to elicit comments and to encourage debate. The views expressed in IMF Working Papers are those of the author(s) and do not necessarily represent the views of the IMF, its Executive Board, or IMF management.

I N T E R N A T I O N A L M O N E T A R Y F U N D 


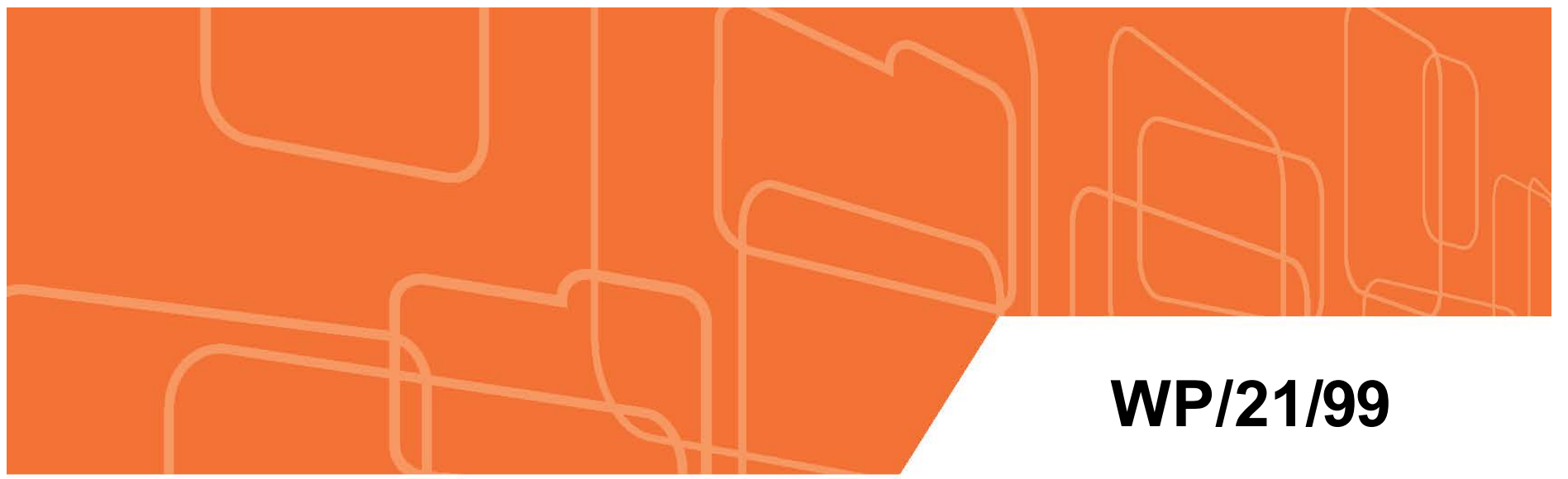

\section{IMF Working Paper}

\section{Smart Containment: Lessons from Countries with Past Experience}

by Alexandra Fotiou and Andresa Lagerborg

IMF Working Papers describe research in progress by the author(s) and are published to elicit comments and to encourage debate. The views expressed in IMF Working Papers are those of the author(s) and do not necessarily represent the views of the IMF, its Executive Board, or IMF management.

$$
\text { I N T E R N A T | O N A L M O N E T A R Y F U N D }
$$




\title{
IMF Working Paper
}

Fiscal Affairs Department

\section{Smart Containment: Lessons from Countries with Past Experience* \\ Prepared by Alexandra Fotiou and Andresa Lagerborg}

Authorized for distribution by Paulo Medas

April 2021

\section{IMF Working Papers describe research in progress by the author(s) and are published to elicit comments and to encourage debate. The views expressed in IMF Working Papers are those of the author(s) and do not necessarily represent the views of the IMF, its Executive Board, or IMF management.}

\begin{abstract}
Following the Great Lockdown in 2020, it is important to take stock of lessons learned. How effective have different containment measures been in slowing the spread of Covid-19? Have containment measures been costly in terms of economic growth, fiscal balances, and accumulated debt? This paper finds that countries with previous SARS experience acted fast and "smart", and were able to contain the virus by relying mainly on public health measures - testing, contact tracing, and public information campaigns - rather than stay-at-home requirements. Using past coronavirus outbreaks as an instrumental variable, we show that countries with past experience were able to contain the virus in a smart way, reducing transmission and deaths while also experiencing higher economic growth in 2020.
\end{abstract}

JEL Classification Numbers: I10, I18, H30, H50

Keywords: COVID-19, containment measures, testing, contact tracing, public information campaigns Author's E-Mail Address: afotiou@,imf.org, alagerborg@imf.org

\footnotetext{
${ }^{*}$ We thank Raphael Espinoza, Pa olo Mauro, Joni Mayfield, Paulo Medas, Catherine Pattillo, members of the FAD Fiscal Policy and Surveillance division, and Katja Funkeand Manabu Nose for useful suggestions. We would a lso like to thank Yuan Xiang for excellent research assistance. The views expressed here are those of our own and do not represent those of the International Monetary Fund.
} 


\section{Contents}

1 Introduction $\underline{2}$

2 Narrative Discussion of Success Stories $\underline{6}$

3 Data and Descriptive Statistics $\quad \underline{10}$

4 Empirical Analysis $\underline{13}$

4.1 The effectiveness of Covid-19 containment measures . . . . . . . . 13

4.2 Does saving lives imply higher economic and fiscal costs? . . . . . . . 16

5 Concluding Remarks $\underline{22}$

A Appendix $\underline{\mathbf{2 5}}$

A.1 Figures and Tables .................... 25 


\section{Introduction}

Covid-19 has had a profound impact around the globe. The human cost of the pandemic has intensified at an alarming rate, with significant outbreaks in almost every part of the world. In order to save lives, governments have responded with unprecedented measures to prevent the virus from spreading. Responses have ranged from broad lockdowns and stay-at-home orders to more targeted and smarter strategies.

Besides the alarming human cost, the pandemic has hit economies through multiple channels. Global growth in 2020 recorded the worst economic fallout since the Great Depression. As the IMF's Managing Director Kristalina Georgieva pointed out during her Curtain raiser speech for the 2020 Spring Meetings: in January, a positive per capita income growth was expected in over 160 countries in 2020; by April, the picture had reversed and over 170 countries were projected to experience negative per capita income growth.

This paper assesses the effectiveness of containment measures in suppressing the Covid-19 virus and saving lives, in a cost-effective way. First, we study the impact of containment measures implemented in over 150 countries and attempt to identify which measures and strategies were more effective. Second, we explore the economic costs/benefits of containing the pandemic and the effect of containment measures on output, fiscal balances and government debt. As countries calibrate their policies in the aftermath of the Great Lockdown amid fears of future waves and future epidemics, lessons can be drawn across countries about what approaches worked best, in order to overcome this historical crisis and minimize the human and economic cost of future crises. Learning from countries that successfully curbed the virus, we propose a smart strategy of testing, contact tracing, and public information campaigns and targeted stringency early on.

Several studies find that containment measures have been effective in flattening the pandemic curve (e.g. Cowling et al., 2020), especially when implemented early and resulted in effectively reducing mobility (e.g. Deb et al., 2020b). ${ }^{1}$ Our analysis is complementary to this literature and adds to it by focusing on identifying differences

\footnotetext{
${ }^{1}$ On the theoretical front, several recent papers use standard epidemiological models to examine the role of different measures, such as quarantines and testing (e.g. Forslid and Herzing, 2020, Brotherhood et al., 2020).
} 
in the strategies employed by countries who were highly successful in containing the Covid-19 pandemic.

Many countries were proactive when the health shock hit, responding rapidly to contain the spread of the virus and offset the economic impact of the pandemic. Some countries were more successful than others and responded in a "smarter" and more cost-effective way. Our analysis suggests that country success stories in containing Covid-19 have largely stemmed from acting with early stringency measures (e.g. monitoring international travel) and applying strong health measures (e.g. wide-scale testing, contact tracing, and public information campaigns). For example, Asian countries with previous experience in containing SARS outbreaks namely Hong Kong SAR, Taiwan Province of China, Singapore, and Vietnam² acted very quickly with these strong health system measures and targeted stringency, focusing on measures such as international travel controls, school closures, and cancellation of public events, while they did not impose quicker or stricter stayat-home orders, closures of workplaces and transport, or restrictions on gatherings and internal mobility. ${ }^{3}$

Our analysis takes into account the timing of containment measures by differentiating between countries that implemented stronger containment measures on average and those that implemented containment measures early on, defined as the measures in place at the time when the country reached 100 reported Covid-19 cases. ${ }^{4}$ Our analysis also compares the use of different containment measures, distinguishing between those that relied on stringency (e.g. lockdowns, closures, and other restrictions on mobility) compared to public health measures.

We present evidence that lower deaths and more successful containment of Covid-19 in 2020 (as measured by age-adjusted mortality rates) are associated with less stringent containment measures on average throughout the year. By contrast,

\footnotetext{
${ }^{2}$ While Canada also experienced a past SARS outbreak, the country's Covid-19 containment measures were enacted with a comparative lag.

${ }^{3}$ As Chinazzi et al. (2020) show within a global metapopulation disease model, one needs to account for a combination of both travel restrictions and other types of measures to project the contribution of travel restrictions to the spread of the virus.

${ }^{4}$ Deb et al. (2020b) study the effectiveness of early containment defined as the timing at which a measure was first implemented, known in epidemiological terms as the public health response time (PHRT). In comparison, our measure not only accounts for the timing, but also accounts for the intensity/ rigidity of containment. Another difference is that they explicitly exclude international travel restrictions from the measures they analyze, while we find suggestive evidence that this measure is important and was one of the main strategies used early on by countries with success in containing the virus. We thus include it in our analysis.
} 
more successful countries had stronger public health measures. We also show that stringency measures implemented early on helped curb deaths during a large part of the year, although this is not significant in explaining death rates recorded by the end of the year.

Does saving lives imply higher economic and fiscal costs? While many leading scholars and policymakers clearly communicated that saving lives is the utmost priority (Baldwin and di Mauro, 2020), doing "whatever it takes" can impose large costs through lower output and revenues, as well as additional fiscal support in the effort to protect the most economically vulnerable. Flattening the infection curve can result in considerable macroeconomic damage, with studies estimating a 10 percent output loss from reduced economic activity and an equivalent fiscal cost (Gourinchas, 2020). Based on survey data, Coibion et al. (2020) study how lockdown measures affected households' spending decisions and expectations and report that 50 percent of survey participants incurred income losses (averaging 5,293 U.S. dollars) and wealth losses (averaging 33,482 U.S. dollars), which affected their spending decisions. Using daily data of Nitrogen Dioxide $\left(\mathrm{NO}_{2}\right)$ emissions as a proxy for economic activity, Deb et al. (2020a) find that containment measures have resulted in a loss of about 15 percent for industrial production over a 30-day horizon.

Our work contributes to the literature that assesses to what extent there exists a trade-off between saving lives and livelihoods, and the heterogeneous role played by different containment measures. Kaplan et al. (2020) estimate the trade-off between lower death rates and higher economic welfare costs implied by indiscriminate versus partial lockdown measures, tracing what they call the 'pandemic possibility frontier' $(\mathrm{PPF})$. The authors note, however, that they do not evaluate other containment policies that may potentially further flatten or shift inward the PPF, such as contact tracing, widespread testing, border closures, and mandatory quarantines" and suggest this as an important task for future work. ${ }^{5}$

We find that lower deaths and more successful containment of Covid-19 are associated with better growth outcomes in 2020 without impacting countries' fiscal balances. Rather, lower death rates are associated with higher primary balances

\footnotetext{
${ }^{5}$ Deb et al. (2020a) find 'preliminary evidence' that stay-at-home requirements and workplace closures are the costliest in economic terms but also the most effective in curbing infections and deaths, while school closures and international travel appear to be less costly but less successful in lowering COVID-19 infections, but emphasize that results should be treated with caution since many of these measures were often introduced simultaneously.
} 
in 2020 and reduced debt levels in the medium run. However, these results may confound good policy with good luck. To address possible endogeneity concerns and estimate the effect of "smart" types of containment, we employ a two-stageleast-squares approach, where past experience in containing coronavirus epidemics is used as an instrument for death rates. The first stage regression reveals that past experience is associated with significantly lower death rates, controlling for countries' income level, and the F-statistic shows that our instrument is strong. In the second stage, we estimate the impact of lower Covid-19 deaths, instrumented by past experience, on economic performance. Our estimates confirm a positive impact on economic growth in 2020. Results are robust to controlling for the age structure of the population and Covid-19 fiscal support measures, among other sensitivity tests.

Finally, we consider the fact that countries with less experience in containing epidemics, often those less prepared to implement effective testing policies and contact tracing, in many cases resorted to stronger stringency measures over a longer period of time as a way to save lives. Such measures are likely to have reduced deaths while implying a trade-off for economic growth. We show that, in fact, countries with stricter containment measures, on average, experienced lower GDP growth. Interaction effects reveal that Covid-19 death rates are negatively related with economic growth, especially when average stringency measures were high.

Overall, the key implication of our analysis is that there is not necessarily a trade-off between saving lives and saving the economy. Countries in the Asian region with past SARS experience serve as an example: they were effective in containing Covid-19 and mitigating lockdown-associated economic costs due to a common smart strategy marked by targeted stringency and mass testing, contact tracing, and public information campaigns.

Our findings add to the literature of smart containment strategies that point to targeted lockdowns and selective quarantine (e.g. Eichenbaum et al., 2020, Favero et al., 2020, Acemoglu et al., 2020). As Andrabi et al. (2020) highlight, a smart containment strategy should be underpinned by data and contact tracing together with testing and authorities promoting voluntary compliance and trust. Dewatripont et al. (2020) propose a two-test approach to identify workers that are immune and non infectious, in line with Berger et al. (2020) who discuss the importance of test- 
ing and targeted quarantine polices. Baldwin (2020) presents the "Singapore model" — test, track, and trust - to motivate his proposal of a "big bazooka" of testing packages.

The remainder of the paper is organized as follows. Section 2 provides a narrative discussion of countries that successfully contained the Covid-19 pandemic. Section 3 describes the data used in the empirical analysis. Section 4 presents the empirical methodology, results, and policy lessons. Finally, Section 5 concludes.

\section{Narrative Discussion of Success Stories}

Figure 1 plots recorded Covid-19 deaths per million inhabitants by regions of the world. By this metric, Asia and Africa have been highly successful in containing the pandemic. While the reasons are still speculative, population age structure is likely a significant part of the story. More generally, recorded cases and deaths have been substantially lower in lower income countries (Figure 2), partly due to lack of widespread testing, but also because of their younger populations and the strong association between mortality and symptomatic cases and age. However, several Asian countries with relatively older populations and mass testing have been exceptionally successful in containing the spread of Covid-19. One possible explanation is their past experience in containing epidemics.

Before the current Covid-19 pandemic, three historically important epidemics had occurred since 2000: severe acute respiratory syndrome (SARS) in 2003, Middle East respiratory syndrome (MERS) in 2013, and Ebola virus disease (EVD) in 2014. The first two were caused by coronaviruses and the third by ebolavirus. All three were eventually contained largely through public health interventions. In particular, SARS was contained mainly through case detection and isolation, quarantine of close contacts, and enhanced infection control measures in settings where care was provided to infected people.

- SARS resulted in 8,000 recorded cases, including 774 deaths, with Mainland China, Hong Kong SAR, Taiwan Province of China, Canada, Singapore, and Vietnam experiencing significant outbreaks (over 50 cases in each).

- MERS caused over 2,500 cases and 881 recorded deaths, with the largest outbreaks affecting Saudi Arabia, South Korea, and United Arab Emirates (over 
50 cases in each).

- The 2014-2016 Ebola outbreak in West Africa is estimated to have caused over 25,000 cases and 11,000 deaths. Significant outbreaks occurred in Guinea, Liberia, and Sierra Leone. In 2018, another large outbreak occurred in the Democratic Republic of Congo, with over 2,000 confirmed and probable cases reported and 1,357 deaths.

Countries with recent past pandemic experiences have been relatively successful in containing Covid-19 deaths. Countries with past SARS experience in particular saw low cases and deaths per capita, especially considering their population age structure and widespread testing. Countries with past MERS experience had low mortality but much larger outbreaks as measured by the number of cases. Testing was also less prevalent in the lower income countries previously hit by Ebola, and their younger populations helped cushion the hit from the pandemic.

Table 1 ranks the top 30 countries with lowest age-adjusted death rates per capita. $^{6}$ Notably, the six main countries with previous SARS experience all rank within the top-30, except for Canada which ranks 31st. Figure 3 shows the markedly lower incidence of Covid-19 in the top-30 "high success" countries, as well as in the six countries with past SARS experience, compared to the rest of the world.

Arguably, lower death rates could be a result of "good luck" rather than "good policy". For instance, perhaps countries with lower (age-adjusted) death rates were less exposed to the virus due to their geographic position, fewer connections with the rest of the world, or lower population densities reducing the speed of transmission. While these factors may have played a part, we argue that policies have played a much more important role.

For example, countries with past outbreaks of SARS in the Asian region, not only acted faster but also implemented a different strategy overall. Figure 4 shows that these countries ${ }^{7}$ implemented at least some stringency measures remarkably earlier (perhaps due to fears of importing the virus from nearby China) and also

\footnotetext{
${ }^{6}$ Age-adjusted death rates are calculated as the residual when regressing deaths per capita on the share of population aged 70 and above. While ideally we would also control for testing, data is not available for as wide a sample of countries. As such, we chose to consider age-adjusted death rates rather than infection rates since the latter would be likely even more dependent on countries' testing policies.

${ }^{7}$ We exclude China from our initial discussion and the SARS average since it was the place of origin of the epidemic.
} 
had stronger health policies throughout the year. Figure 5 shows that, differently from most other countries, countries with past SARS experience: (i) quickly imposed restrictive measures such as international travel restrictions, school closures, and cancellation of public events, (ii) were proactive in implementing stronger health policies such as public information campaigns, testing policy, and contact tracing; and (iii) relied relatively less on other measures such as stay-at-home requirements, closures of public transport, restrictions on internal mobility. Perhaps due to past experience, public information campaigning seems to have been enough for people to 'act cautiously' and reduce mobility (Figure 6). All in all, their early and smart containment strategies, which included the rapid implementation of targeted stringency and mass testing, contact tracing, and public information campaigns, allowed these countries to successfully curb the spread of the virus, despite their geographic proximity and high interconnection with China, the country of origin of Covid-19.

One particular 'success case' that implemented this strategy is Vietnam, a country that shares a border with China, and by July 15 had only 380 cases and no deaths related to Covid-19 despite large-scale testing. The country's early response and strategic approach (with previous experience with SARS in 2003) included imposing wide-ranging social distancing measures and movement restrictions early on, mobilizing a large number of contact tracers (using a low-cost approach), and a strong public information campaign. Implementing these measures allowed Vietnam to successfully contain the virus, much more so than the Philippines, which has approximately the same population and similar proximity to China, but which imposed various containment measures with a comparative delay (Figure 7). According to the Lowy Institute's Covid Performance Index, which ranks countries' performance in managing the COVID-19 pandemic in the 36 weeks following their hundredth confirmed case of the virus, Vietnam ranks 2nd place while the Philippines ranks 79th. This is despite Vietnam beginning to ease lockdown restrictions as early as April 23rd.

Other countries with "high success" in containing (age-adjusted) Covid-19 death rates shown in Table 1, include several smaller Northern European countries (e.g. Finland, Estonia, Norway, Denmark, Iceland, Latvia), several islands in Asia (e.g. Japan, New Zealand, Australia, Fiji, Sri Lanka), the Caribbean (Barbados, Jamaica, Trinidad and Tobago), Africa (Mauritius), and Europe (Cyprus, Greece), 
and various other mainland countries (e.g. Uruguay, Germany, Thailand, Malaysia, Canada). ${ }^{8}$ While it may be that these countries have their own specificities for one reason or another, note that their successful containment of Covid-19 contrasts with the experiences in neighboring countries such as in Sweden and Lithuania in Northern Europe (ranked 130th and 95th), islands such as the United Kingdom, the Bahamas, Cabo Verde, and Dominican Republic (ranked 140th, 122nd, 107th, 104th), islands in Asia such as the Philippines and Indonesia (ranked 92nd and 70th), and other neighboring mainland countries in South America (e.g. Brazil, Argentina, Paraguay, ranked 151st, 148th, and 117th), Europe (e.g. Belgium, France, Luxembourg, ranked 156th (last), 134th, and 131st), and North America (the United States, ranked 145th). These successful countries, on average, acted with somewhat earlier stringency measures compared to other countries and were able to strengthen health measures more quickly, over time converging to the health measures of countries with past SARS experience (Figure 4). In particular, they more rapidly strengthened their testing policy and also maintained stricter international travel controls throughout the year, while relaxing most domestic stringency measures compared to other countries (Figure 5). Note that at the time of 100 reported cases, these countries did not have, on average, tighter stringency measures nor stronger public health measures in place (Figure 8). Strengthening their public health measures, such as testing and contact tracing, was a learning process as most lacked prior recent experience in using these methods to control pandemics. In contrast, countries with past SARS experience put in place stronger public health measures from the onset.

It is also worth noting that the composition of the group of successful countries in containing Covid-19 changed with subsequent waves. For example, in Europe, countries like Lithuania, the Slovak Republic, Austria, Georgia, Croatia, and Slovenia, which had been highly successful in containing the virus up until September 2020, were unable to contain its spread in the last quarter of 2020, when a second strong wave hit the continent. Figure 9 shows the containment measures enacted by countries that had successfully contained Covid-19 until September 2020 but were unsuccessful thereafter, compared to those which remained successful throughout the remainder of the year. It appears that the former (successful only in wave 1) relaxed several stringency measures, both pertaining to international travel controls

\footnotetext{
${ }^{8}$ Note that data underreporting is a caveat of this ranking.
} 
and domestic restrictions, relatively more than their counterparts that were subsequently more successful. This reduction in stringency measures, may have caused cases to surge.

\section{$3 \quad$ Data and Descriptive Statistics}

Our analysis draws on cross-sectional data for over 150 countries, covering the following variables:

Covid-19 Containment measures. Daily data of government measures to contain the spread of Covid-19 is obtained from the Oxford Coronavirus Government Response Tracker (OxCGRT) spanning January 1- December 31, 2020 and covering over 150 countries. The overall government response index takes into account 19 indicators on: (i) containment and closure policies (8 indicators), (ii) health system policies (7 indicators), and (iii) economic policies (4 indicators). The subindices include: (i) school closures, workplace closures, cancellation of public events, restrictions on gathering, public transport closures, stay-at-home requirements, restrictions on internal movement, and international travel controls; (ii) public information campaigns, testing policy, contact tracing, announced investment in healthcare, announced spending on vaccine development, facial covering requirements, and vaccination policies; and (iii) cash payments to households, freezes on financial obligations for households, announced economic stimulus spending, and international support to other countries. ${ }^{9}$

We make use of three main containment indicators throughout our analysis:

1. 'Overall containment measures': This is taken to be the overall 'containment and health index' reported by OxCGRT, which summarizes all containment and closure policies ( 8 indicators) as well as the 3 first indicators relating to health system policies (public information campaigns, testing policy, and contact tracing).

2. 'Stringency measures': This is taken to be the 'stringency index' reported by OxCGRT, which summarizes all containment and closure policies (8 indicators) as well as the first indicator relating to health system policies (public

\footnotetext{
${ }^{9}$ Detailed information is available on: https://github.com/OxCGRT/covid-policy-tracker/ blob/master/documentation/codebook.md\#codebook-changelog
} 
information campaigns). This indicator intends to capture policies that restrict people's movements such as closures and stay-at-home orders.

3. 'Public health measures': We construct a principal component of the 3 first indicators relating to health system policies (public information campaigns, testing policy, and contact tracing). As such, this indicator focuses on 'smart' health measures.

We further aggregate the daily data into two main summary indicators:

1. 'Average strength' of containment measures, defined as the average value over the year (or corresponding sub-period). This does not take into account the timing of when measures were put in place.

2. 'Early strength' of containment measures, defined as the measures in place when the 100th case was recorded. This accounts for the timing of when measures were put in place.

Note that we normalize all containment indicators on a $0-1$ scale.

Covid-19 death and cases. We use daily data on recorded Covid-19 cases and deaths from Our World in Data (OWID) database. ${ }^{10}$ We complement this with data from the Coronavirus Resource Center of Johns Hopkins University, which tracks daily Covid-19 statistics from official country announcements on testing, infections, deaths and recoveries. ${ }^{11}$.

Covid-19 containment success. We make use of Lowy Institute's Covid-19 Performance Index, which measures 98 countries' relative success in managing Covid-19 in the 36 weeks that followed countries' 100th confirmed case (based on confirmed cases and deaths, totals as well as per capita, cases as a proportion of tests, and tests per thousand people). We also construct our own ranking of containment success based on age-adjusted death rates (calculated as the residual after regressing death rates on the share of population over age 70) for our larger sample of over 150 countries.

Macroeconomic variables. Macroeconomic variables are taken from the IMF's World Economic Outlook (WEO) database, including data on: GDP per capita (in PPP USD terms), real GDP growth, real per capita GDP growth, the primary

\footnotetext{
$10_{\text {https: / / ourworldindata.org. }}$

${ }^{11}$ https : // coronavirus.jhu. edu/map.html
} 
balance (as a percent of GDP), and gross public debt (as a percent of GDP). The primary data source of data is the January 2021 WEO. However, we also look into projection revisions across different vintages (October 2019, January 2020, July 2020, October 2020) of the WEO database.

Fiscal support measures. Data on Covid-19 fiscal support measures are obtained from the IMF's policy tracker on policy responses and the IMF Fiscal Monitor database of Covid-19 Fiscal Response Measures published in June 2020, October 2020, and January 2021. ${ }^{12}$ We primarily make use of total above-the-line fiscal support announcements as well as amounts implemented in 2020, where the data are measured as a percent of GDP.

Mobility. We make use of Google's Community Mobility Report data, which contains daily data on movement trends by country, across different categories of places such as retail and recreation, groceries and pharmacies, parks, transit stations, workplaces, and residential. We create a principal component that summarizes the different categories into an overall indicator of mobility. We also make use of Apple Map's Mobility Trends Report dataset. ${ }^{13}$

Health preparedness. Data on hospital beds per thousand inhabitants are obtained from Our World In Data.

Population age, size, and density. Population age, size, and density data are taken from Our World in Data.

WEO country income groups. We classify countries according to the WEO's country income groups, as advanced economies (AEs), low-income developing countries (LIDCs) and other emerging market and developing economies (EMDEs), and note relevant differences in death rates, containment measures, and macroeconomic performance across these groups. We control for these country groups throughout our analysis.

Figure 2 shows the markedly higher incidence of Covid-19 cases and deaths reported by advanced economies, followed by emerging markets, and least by lowincome developing countries. This reflects differences such as reporting, testing policy, demographics, connectivity, and containment measures across the groups.

\footnotetext{
12 https://www.imf.org/en/Topics/imf-and-covid19/Policy-Responses-to-COVID-19

13 https://www .apple.com/covid19/mobility
} 
Figure 10 shows box plots of Covid-19 containment measures according to country income groups. Stringency measures were on average stricter in emerging markets, while more stringent measures were in place earlier (at 100 cases) in developing countries. Advanced economies had stronger average health policies, whereas early health policies were similar across country groups.

Figure 11 plots GDP growth for different WEO data vintages by country income groups. The largest economic contractions in 2020 were experienced by emerging markets, followed by advanced economies, and smallest for low-income developing countries. At the same time, primary deficits and increases in public debt were largest for advanced economies, followed by emerging markets, and smallest for low-income developing countries (Figure 12). This is in line with the fact that Covid-19 fiscal support measures were substantially larger for advanced economies relative to developing countries, as measured by total above-the-line support as a share of GDP (Figure 13).

\section{Empirical Analysis}

This section presents empirical evidence on the impact of Covid-19 containment. First, we study the role of containment measures in reducing the spread and severity of the pandemic, as measured by the number of deaths per capita, focusing on the strategies employed by more successful countries. Second, we assess the effect of containing Covid-19 on the macroeconomy and countries' public finances.

\subsection{The effectiveness of Covid-19 containment measures}

As highlighted in the literature review above, several studies have shown that different government measures have been effective in containing the spread of Covid19. For example, Cowling et al. (2020) show that non-pharmaceutical interventions (e.g. social distancing measures) and behavioral changes were effective in reducing the incidence of Covid-19 infections. Deb et al. (2020b) show using local projection methods that stringency measures, such as stay-at-home requirements, reduced the number of deaths, especially when implemented early and when they resulted in less mobility.

In this section, we do not intend to dispute the consensus that containment measures were successful in reducing the spread of the virus. Instead, our focus 
is on detecting 'smart' measures. What were the containment measures taken by countries who successfully contained the pandemic, and how did they differ from policies adopted by other countries? In particular, we highlight the importance of distinguishing between stringency measures (such as lockdown restrictions) and health policy measures (such as widespread testing and contact tracing). We also highlight the relevance of imposing containment measures early on, before the virus becomes widespread.

As a "quick-and-dirty" way to study the effectiveness of stringency measures in containing the virus, we estimate the following cross-country regression:

$$
\text { Death } \text { rate }_{i}=\beta_{0}+\beta_{1} C_{i}+\beta_{2} X_{i}+u_{i}
$$

where Death rate $_{i}$ denotes the death rate per thousand inhabitants in country i, while $C_{i}$ captures Covid-19 containment measures (i.e., the average level of containment measures since March 2020 and the level of containment measures implemented early on, when the country had only 100 recorded cases of Covid-19), $X_{i}$ includes the set of control variables - country-specific characteristics, such as median age and health care capacity (proxied by hospital beds per capita), GDP per capita and WEO country income groupings -, and $\beta_{0}$ and $u_{i}$ denote the constant and error term, respectively.

We note that this specification does not address endogeneity concerns - a caveat inherent also in the aforementioned studies - and thus causality should be interpreted with caution. For example, it is plausible that stronger containment measures are put in place precisely because the rate of Covid-19 transmission is high, which would bias coefficient estimates of the effectiveness of containment measures in reducing deaths. As such, the regression estimates should be interpreted as correlations rather than causal relations.

Tables 2 and 3 present evidence on containment measures being associated with curbing deaths. ${ }^{14}$ In particular, in the case where strong stringency measures are implemented early on (at the time of 100 cases) these measures are significantly associated with lower deaths up until October $2020 .{ }^{15}$ This is consistent with others'

\footnotetext{
${ }^{14}$ Results are robust to including additional control variables e.g. population size and density.

${ }^{15}$ Note from Figure 1 that the period up to October 2020 corresponds to the period that all countries in our sample and different regions experienced their first Covid-19 wave.
} 
findings (e.g. Deb et al., 2020b) that stringency measures have mattered particularly early on. Stronger overall public health measures (on average during the sample period) are also associated with lower deaths per capita. By contrast, stronger overall stringency (on average during the sample period) is positively associated with deaths per capita, likely due to an endogenous relationship whereby stringent containment measures are put in place for longer in places where the pandemic is less contained. The control variables carry the expected signs: countries with a more elderly population and lower health preparedness had higher death rates.

Since many of the containment measures have often been implemented at the same time, it is difficult to disentangle between their effects. While acknowledging that their study is also subject to these caveats, Deb et al. (2020b) suggest that stay-at-home orders were among the most effective measures. ${ }^{16}$ By contrast, we find a different subset of containment measures to be associated with higher success in containing Covid-19. Table 4 shows that most stringency measures individually are positively related with country death rates (due to reverse causality), with the exception of international travel controls, for which policies often differed from domestic measures and evidence seems to be strong in favor of reducing contagion. This is in line with narrative evidence of successful countries with past experience from the SARS coronavirus (Figure 5) that imposed international travel restrictions very early on (e.g. Taiwan Province of China, Vietnam, Hong Kong SAR, Singapore) to decrease the risk of importing the disease. We also find robust evidence in favor of strong health policies (e.g. widespread testing) being associated with lower death rates. Note that while Deb et al. (2020b) explicitly excluded international travel controls and public health policies from the measures considered in their analysis, we consistently find evidence that these seem to be among the most effective containment measures (employed the most by successful countries).

Table 5 presents $t$-test statistics for differences in mean containment measures between countries with high success in containing Covid-19 in 2020 (the 30 countries with lowest age-adjusted mortality rates) compared to the rest of the sample of countries. Notably, countries that were more successful in containing the pandemic did not have stronger containment measures in place early on (at the time of 100

\footnotetext{
${ }^{16}$ The authors estimate the impact of different containment measures using local projection methods, with country fixed effects that capture country-specific characteristics (such as population age, density, etc), which we have also tried to capture in our control variables.
} 
cases), suggesting that although this was associated with lower deaths earlier on in the year, this was not the main determinant of success by the end of the year. However, they had stronger health measures, including testing policy and contact tracing, as well as stronger international travel controls in place throughout the year. Their stringency policies, instead, were less strict on average throughout the year, as success in containing the virus early on meant they could subsequently relax certain stringency measures relatively more. Table 6 confirms these findings using regression analysis, showing that a higher success rank is associated with a lower Covid-19 death rate and also with more relaxed containment policies (especially regarding stringency measures), on average in 2020, but stronger health policies and travel controls.

Table 7 regresses the Lowy Institute's Covid Performance Index, which measures countries' relative success in managing Covid-19 in the 36 weeks that followed countries' 100th confirmed case, on containment measures. In line with the evidence already presented, countries that were less successful in containing Covid-19 had more stringent measures in place on average (due to reverse causality), while countries with stronger health measures on average fared better in containing the virus. A similar case holds for international travel controls, which appear to have been employed more by countries that performed better in managing Covid-19. In addition, countries with more stringent measures in place early on (at 100 cases) also performed better in managing Covid-19. This confirms the relevance of early stringency measures.

\subsection{Does saving lives imply higher economic and fiscal costs?}

This section provides empirical evidence on the impact of lower Covid-19 deaths per capita on countries' economic outcomes. Our evidence runs against the idea that saving lives necessarily came at a higher economic and fiscal cost. First, we show that lower deaths per capita are associated with higher economic growth, without significantly impacting countries' primary balances and without being associated with significantly different fiscal support packages. Second, we show that countries with a higher success ranking (lower age-adjusted mortality rates) also experienced higher GDP growth without significantly different fiscal costs. Third, using countries' recent past experience in containing epidemics as an exogenous instrument, we 
confirm that containing Covid-19 deaths is associated with higher growth in 2020, without significantly impacting countries' medium-term fiscal position.

We estimate the following regression:

$$
Y_{i, h}=\beta_{0}+\beta_{1} \text { Death } \text { rate }_{i}+\beta_{2} X_{i}+u_{i}
$$

where $Y_{i, h}$ denotes the outcome variable in country $i$ at time horizon $h=2020, \ldots, 2025$. The set of control variables $X_{i}$ includes log GDP per capita in U.S. dollar PPP terms and WEO country income groups. In each regression $\beta_{0}$ and $u_{i}$ are the constant and error term, respectively.

We consider the following outcome variables from the IMF's World Economic Outlook (WEO): real GDP per capita growth rates, real GDP growth rates, the primary balance as a share of GDP, and public debt as a share of GDP. Using the January 2021 WEO vintage, we consider the actual level of these indicators in 2020 (and projections beyond then), as well as the difference versus 2019, and the WEO revisions vis-a-vis the January 2020 vintage of the WEO. ${ }^{17}$ We also consider the impact on Covid-19 fiscal support packages using data from the IMF's Fiscal Monitor database.

\section{The Role of Covid-19 Deaths}

We find that countries with higher Covid-19 death rates experienced relatively worse economic performance, while having insignificantly different fiscal out-turns. Tables 8 and 9 show that countries with more significant Covid-19 outbreaks, as measured by cumulative Covid-19 deaths per capita, saw: (i) larger downward growth forecast revisions for each of the WEO forecast publications in 2020, (ii) a sharper fall in growth compared to 2019, and (iii) a significantly lower realized growth rate in 2020. ${ }^{18}$ Table 10 shows that higher deaths per capita were not associated with significantly different primary balances (or changes vis-a-vis previous forecasts or compared to 2019 levels). Table 11 shows that countries with larger Covid-19 outbreaks did not provide larger fiscal support (support actually implemented in 2020 out of the total package) (column 1) or announce larger fiscal support packages

\footnotetext{
${ }^{17}$ Results are robust to different vintages for the base year, e.g. considering changes vis-a-vis the October 2019 vintage of the WEO.

${ }^{18}$ Results are robust to including additional controls, e.g. oil exporter and commodity exporter dummies.
} 
as of January 2021 nor October 2020 (columns 2-3), according to the IMF Fiscal Monitor's Covid-19 Fiscal Measures databases. ${ }^{19}$ To further test whether the weak relationship between the size of fiscal support and countries' Covid-19 outbreaks holds across country income groups, we further interact Covid-19 death rates with a dummy for advanced economies, and find that advanced economies that experienced higher death rates actually announced relatively smaller fiscal support packages as of late 2020/early 2021.

Turning to medium-term projections, reduced Covid-19 deaths are associated with higher GDP growth in 2020, but lower GDP growth in 2021, and insignificantly different economic growth projections for future years (Figure 14). Regarding effects on public finances, no significant difference is observed for primary balances nor public debt as a share of GDP throughout the forecast horizon (Figure 15).

\section{The Role of Successfully Containing Covid-19}

We present similar analyses considering our Covid-19 success ranking of countries by age-adjusted mortality rates. Again, we find evidence that countries that more successfully contained Covid-19 saw higher GDP growth rates in 2020 (Table 12) and an insignificantly different impact on their public finances in 2020 as measured by their primary balance and fiscal support as a share of GDP (Table 13).

Turning to medium-term projections, lower age-adjusted mortality rates (higher success ranking) are associated with higher GDP growth in 2020 and insignificantly different economic growth projections for 2021 and beyond (Figure 16). Regarding effects on public finances, a borderline significantly higher primary balance is observed in 2020 and public debt is projected at significantly lower levels for most of the forecast horizon, controlling for 2019 levels (Figure 17).

\section{Approach: The Role of Past Coronavirus Experience}

Yet, is better success in containing Covid-19 a product of good ('smart') containment policy or good luck? It could be that out of sheer 'luck' some countries were hit less strongly by the pandemic, and therefore experienced both lower death rates and higher growth. To estimate the impact of good policy (smart containment of Covid-19), we consider that past coronavirus epidemic experience could act as

\footnotetext{
${ }^{19}$ We focus on above-the-line measures because of larger data availability across countries. However, results are robust to including off-budget and below-the-line fiscal support measures as well.
} 
an instrument for Covid-19 death rates. We thus construct a dummy variable for the nine countries with past coronavirus pandemic experiences from SARS (Taiwan Province of China, Singapore, Vietnam, Canada, Mainland China, and Hong Kong SAR) and MERS (Saudi Arabia, South Korea, and United Arab Emirates).

We employ two-stage-least-squares (2SLS) regression methods. The first stage shows that past experience is significantly associated with lower Covid-19 deaths per capita (Table 14, column 1). Moreover, the past experience dummy passes the weak instrument test with an F-statistic of 17.6 (above the Staiger-Stock rule of thumb of 10). The second stage of the regression shows that lower Covid-19 deaths, instrumented by past experience, are associated with higher real GDP growth in 2020, and a relatively better performance compared to 2019 and compared to the outcome expected in January 2020 (Table 14, columns 2-7). Table 15 shows that lower Covid-19 deaths is also associated with lower primary balances and higher fiscal support in 2020. In other words, countries with higher success in containing Covid-19 based on past experience, also offered larger fiscal support, which may partly explain their better growth performance.

Turning to medium-term projections, successfully containing Covid-19 deaths as a result of past experience, is associated with higher GDP growth in 2020, but not significantly different economic growth projections for future years (nor significantly different revisions to medium-term growth projections relative to the January 2020 WEO) (Figure 18). Regarding public finances, while a lower primary balance is observed in 2020 (due to larger fiscal support), no significant difference is observed for public debt as a share of GDP (Figure 19). In fact, if anything, the public debt path is projected to be lower (significant at the $68 \%$ level).

Our findings remain robust to various sensitivity tests (Table 16). Results are robust to controlling for the median age of the population, which help explain death rates and improve the first-stage F-statistic (columns 1-3). The impact on growth is also robust to controlling for economic policies such as Covid-19 fiscal support measures implemented in 2020, which are important in explaining the primary balance (columns 4-6). ${ }^{20}$

\footnotetext{
${ }^{20}$ Results are also robust to additional tests e.g. controlling for oil and commodity exporter dummies, which may help explain economic performance and fiscal revenues. Results are available from the authors upon request.
} 
We also test robustness of our results to variations in our instrument for past experience in containing epidemics (Table 17). Our findings remain robust to: (i) including in our dummy instrument countries who experienced Ebola in the past, as well as (ii) considering in our instrument only countries who experienced SARS (not MERS or Ebola). Considering the wider set of past epidemics, past experience (from SARS, MERS, and Ebola) remains significantly associated with lower Covid-19 death rates, controlling for log GDP per capita and country income group dummies (column 1). Similarly, focusing on countries with past SARS experience is also significantly associated with lower Covid-19 death rates (column 5). Using either instrument, lower Covid-19 deaths (instrumented by past experience) is associated with higher GDP growth in 2020 (columns 2 and 6), independent of whether or not this involved larger fiscal support.

\section{The Role of Covid-19 Containment measures}

The analysis above shows that higher success in containing Covid-19 through smart containment strategies was associated with better growth outcomes. Smart containment enabled some countries to successfully contain Covid-19 early, and allowed them to reduce containment measures later on in 2020. By contrast, other less successful countries in many cases had strong containment measures in place for longer in order to curb the spread of Covid-19. Stringency measures, while important to flatten the infection curve, also reduce economic growth by restricting people's movements and activities.

To study the relation between economic performance and containment measures taken by governments to slow the spread of Covid-19, we estimate:

$$
Y_{i}=\beta_{0}+\beta_{1} C_{i}+\beta_{2} X_{i}+u_{i}
$$

where $Y_{i}$ denotes country $i$ 's outcome variable of interest in 2020 (GDP growth, primary balance, or fiscal support measures), and $C_{i}$ denotes the containment measures implemented on average throughout the year. The set of control variables $X_{i}$ includes log GDP per capita in U.S. dollar PPP terms and WEO country income groups, while $\beta_{0}$ and $u_{i}$ are the constant and error term, respectively.

Table 18 shows that stronger average Covid-19 containment measures were associated with lower economic growth, and this was driven by stringency mea- 
sures whereas health policies are insignificant. This could plausibly be due to larger outbreaks in those countries slowing down economic activity. Table 19 shows that accounting for death rates is part of the story. After controlling for deaths, weaker evidence still suggests that higher average stringency may have mattered in slowing economic activity. Higher deaths, controlling for stringency measures, are also associated with lower activity, possibly due to voluntary social distancing (people consuming and/or producing less because of being scared of catching Covid-19). This is in line with recent evidence showing that what matters the most is the voluntary decision of people to social distance and take precautions, rather than de-jure non-pharmaceutical interventions (Chen et al., 2020). Interaction effects are also found to matter: the marginal effect of the Covid-19 death rate is lower (negative and significant) for economic growth when this comes at the cost of higher average stringency measures (Figure 20). Moreover, controlling for mobility fully explains any effects captured by stringency measures. Results are largely robust to measuring economic activity in terms of GDP growth rather than GDP per capita growth (Tables 20 and 21).

Table 22 (columns 3 and 6) shows that countries with stronger average Covid19 measures (explained by stronger stringency measures) saw larger downward revisions in their primary balances. This result is robust to controlling for the severity of the pandemic (Covid-19 deaths) and reduced mobility (Table 23). This is, however, not explained by larger fiscal support in 2020 (Table 24 column 3 and Table 25), except for in combination with controlling for Covid-19 deaths (Table 24 column 6). In general, we do not find evidence that fiscal support packages depended on containment measures (average stringency) or on the severity of the pandemic (Covid-19 death rates) or on the extent to which mobility was reduced (Table 26). The exception is for advanced economies, where fiscal support was larger in 2020 in countries that applied more stringent containment measures (Table 25, column 4). Fiscal space is likely to have constrained fiscal support in many countries, and especially those with lower income. As a result, more stringent containment measures imposed by country governments were not, on average, accompanied by more fiscal support to cushion the impact on the economy. 


\section{Concluding Remarks}

Countries have taken a variety of approaches to 'flatten the curve' of Covid-19 infections. Our results show that countries that imposed stronger containment measures on average experienced higher output losses, whereas countries that were able to contain the spread of Covid-19 through smart containment measures fared better in terms of economic growth. Lessons can be learned from these examples. Some of the more successful cases, including countries with experience in containing past epidemics, relied on an effective combination of early restrictions (including travel controls) and smart containment strategies based on large-scale testing, contact tracing, and public information campaigns. Authorities should prepare themselves to adopt smart strategies to fight possible new waves of infections and remember these lessons for future pandemics. 


\section{References}

Acemoglu, D., V. Chernozhukov, I. Werning, and M. D. Whinston (2020). Optimal targeted lockdowns in a multi-group sir model. Technical report, Working Paper 27102, National Bureau of Economic Research May.

Andrabi, T., M. Andrews, A. Cheema, J. Das, A. Q. Khan, A. I. Khwaja, F. Majid, A. A. Malik, A. Malkani, T. McCormick, S. Omer, and M. Syed (2020). Smart containment with active learning (scale): A proposal for a data-responsive and graded response to covid-19 working draft. Technical report, mimeo.

Baldwin, R. (2020). Covid-19 testing for testing times: Fostering economic recovery and preparing for the second wave. VOX CEPR Policy Portal, 26th March.

Baldwin, R. and B. W. di Mauro (2020). Mitigating the covid economic crisis: Act fast and do whatever it takes. VoxEU. org eBook.

Berger, D. W., K. F. Herkenhoff, and S. Mongey (2020). An seir infectious disease model with testing and conditional quarantine. Technical report, National Bureau of Economic Research.

Brotherhood, L., P. Kircher, C. Santos, and M. Tertilt (2020). An economic model of the covid-19 epidemic: The importance of testing and age-specific policies.

Chen, S., I. Deniz, N. Pierri, and A. Presbitero (2020). Tracking the economic impact of covid-19 and mitigation policies in europe and the united states. forthcoming IMF Working Paper $\%$.

Chinazzi, M., J. T. Davis, M. Ajelli, C. Gioannini, M. Litvinova, S. Merler, A. P. y Piontti, K. Mu, L. Rossi, K. Sun, et al. (2020). The effect of travel restrictions on the spread of the 2019 novel coronavirus (covid-19) outbreak. Science 368(6489), 395-400.

Coibion, O., Y. Gorodnichenko, and M. Weber (2020). The cost of the covid-19 crisis: Lockdowns, macroeconomic expectations, and consumer spending. Technical report, National Bureau of Economic Research.

Cowling, B. J., S. T. Ali, T. W. Ng, T. K. Tsang, J. C. Li, M. W. Fong, Q. Liao, M. Y. Kwan, S. L. Lee, S. S. Chiu, et al. (2020). Impact assessment of nonpharmaceutical interventions against coronavirus disease 2019 and influenza in hong kong: an observational study. The Lancet Public Health.

Deb, P., D. Furceri, J. Ostry, and N. Tawk (2020a). The economic effects of covid-19 containment measures. Covid Economics 24, 32-75.

Deb, P., D. Furceri, J. Ostry, and N. Tawk (2020b). The effect of containment measures on covid-19 pandemic. Covid Economics 19, 53-86.

Dewatripont, M., M. Goldman, E. Muraille, and J.-P. Platteau (2020). Rapidly identifying workers who are immune to covid-19 and virus-free is a priority for restarting the economy. VOX CEPR Policy Portal 23.

Eichenbaum, M. S., S. Rebelo, and M. Trabandt (2020). The macroeconomics of epidemics. Technical report, National Bureau of Economic Research. 
Favero, C. A., A. Ichino, and A. Rustichini (2020). Restarting the economy while saving lives under covid-19.

Forslid, R. and M. Herzing (2020). Assessing the consequences of quarantines during a pandemic.

Gourinchas, P.-O. (2020). Flattening the pandemic and recession curves. Mitigating the COVID Economic Crisis: Act Fast and Do Whatever it Takes 31.

Kaplan, G., B. Moll, and G. L. Violante (2020). The Great Lockdown and the Big Stimulus: Tracing the Pandemic Possibility Frontier for the U.S. Technical report. 


\section{A Appendix}

\section{A.1 Figures and Tables}

Figure 1: Global Waves of Covid-19 in 2020

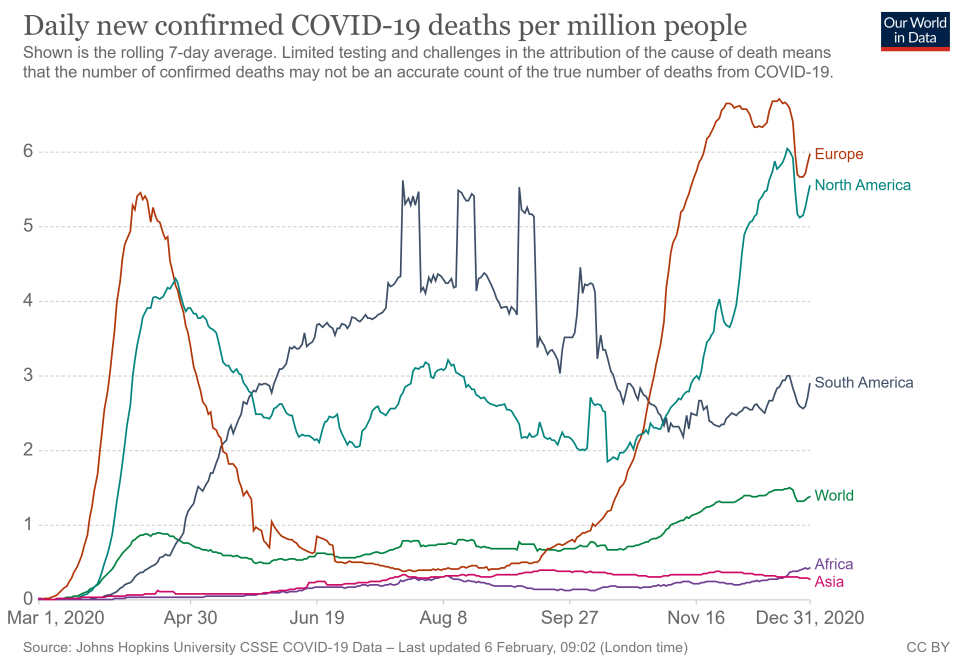

Figure 2: Covid-19 Incidence by Income Group
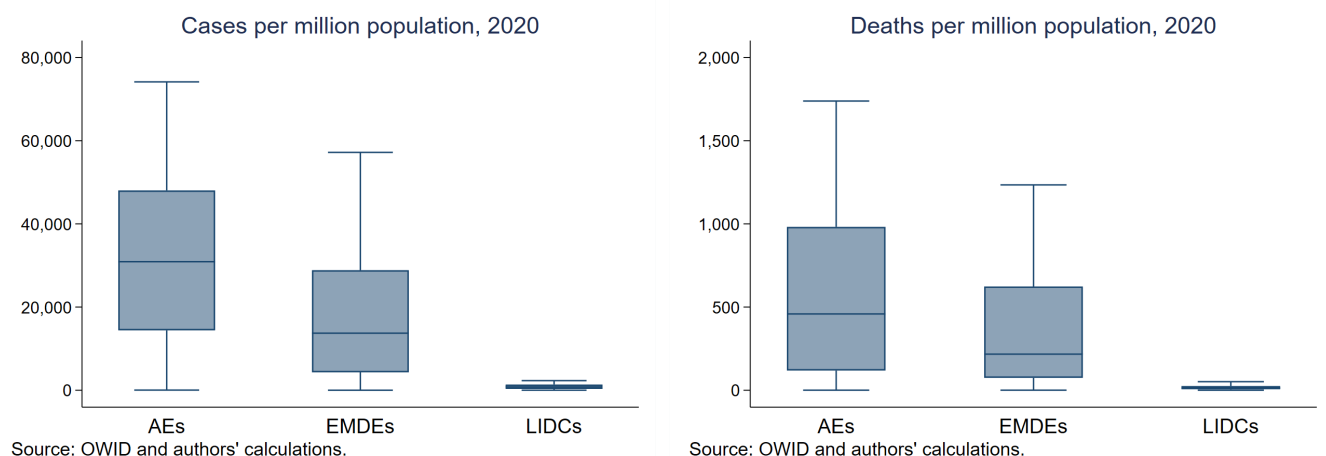

Source: OWID and

Source: OWID and authors' calculations. 
Table 1: 2020 Success Stories in Covid-19 Containment

\begin{tabular}{|c|c|c|c|c|c|c|c|c|c|}
\hline \multirow[b]{4}{*}{ Country } & \multicolumn{9}{|c|}{ Success in Containing Covid-19 } \\
\hline & \multicolumn{3}{|c|}{ Top 30 Success in 2020} & \multicolumn{3}{|c|}{ Top 30 Success until Oct. 2020} & & \multirow{2}{*}{\multicolumn{2}{|c|}{$\begin{array}{c}\text { Lowy's Recent } \\
\text { Covid Perf. Epidemic }\end{array}$}} \\
\hline & Age-Adj. & Deaths & Cases & Age-Adj. & Deaths & Cases & Pop share & & \\
\hline & \multicolumn{3}{|c|}{ Ranking per million per million } & Ranking & per million & \multicolumn{2}{|c|}{ er million > age 70} & \multirow{2}{*}{\multicolumn{2}{|c|}{$\begin{array}{l}\text { Ranking Experience } \\
45\end{array}$}} \\
\hline Japan & 1 & 26 & 1864 & 1 & 14 & 801 & 18.5 & & \\
\hline Finland & 2 & 101 & 6517 & 6 & 65 & 2908 & 13.3 & 17 & \\
\hline Estonia & 3 & 173 & 21100 & 5 & 55 & 3698 & 13.5 & 11 & \\
\hline Hong Kong SAR & 4 & 20 & 1178 & 9 & 14 & 709 & 10.2 & - & SARS \\
\hline New Zealand & 5 & 5 & 448 & 7 & 5 & 406 & 9.7 & 1 & \\
\hline Australia & 6 & 36 & 1115 & 14 & 36 & 1082 & 10.1 & 8 & \\
\hline Uruguay & 7 & 52 & 5504 & 8 & 17 & 899 & 10.4 & 12 & \\
\hline Norway & 8 & 80 & 9143 & 15 & 52 & 3750 & 10.8 & 18 & \\
\hline Barbados & 9 & 24 & 1333 & 13 & 24 & 825 & 9.5 & - & \\
\hline Taiwan Province of China & 10 & 0 & 34 & 11 & 0 & 23 & 8.4 & 3 & SARS \\
\hline South Korea & 11 & 18 & 1205 & 12 & 9 & 520 & 8.6 & 20 & MERS \\
\hline Germany & 12 & 403 & 21013 & 10 & 125 & 6347 & 16.0 & 55 & \\
\hline Denmark & 13 & 224 & 28334 & 27 & 124 & 8091 & 12.3 & 23 & \\
\hline Iceland & 14 & 85 & 16862 & 16 & 35 & 14256 & 9.2 & 7 & \\
\hline Latvia & 15 & 337 & 21686 & 2 & 38 & 3125 & 14.1 & 9 & \\
\hline Singapore & 16 & 5 & 10016 & 20 & 5 & 9917 & 7.0 & 13 & \\
\hline Thailand & 17 & 1 & 103 & 17 & 1 & 54 & 6.9 & 4 & \\
\hline Belarus & 18 & 151 & 20561 & 29 & 104 & 10422 & 9.8 & 60 & \\
\hline Cyprus & 19 & 136 & 25139 & 18 & 30 & 4985 & 8.6 & 5 & \\
\hline China & 20 & 3 & 67 & 22 & 3 & 63 & 5.9 & - & SARS \\
\hline Mauritius & 21 & 8 & 414 & 24 & 8 & 347 & 5.9 & - & \\
\hline Greece & 22 & 464 & 13321 & 3 & 60 & 3766 & 14.5 & 32 & \\
\hline Sri Lanka & 23 & 10 & 2022 & 25 & 1 & 498 & 5.3 & 10 & \\
\hline Vietnam & 24 & 0 & 15 & 28 & 0 & 12 & 4.7 & 2 & SARS \\
\hline Jamaica & 25 & 102 & 4332 & 35 & 70 & 3071 & 6.4 & 31 & \\
\hline Trinidad and Tobago & 26 & 91 & 5109 & 62 & 77 & 4067 & 5.8 & 28 & \\
\hline Fiji & 27 & 2 & 55 & 31 & 2 & 38 & 3.3 & - & \\
\hline Malaysia & 28 & 15 & 3492 & 33 & 8 & 975 & 3.4 & 16 & \\
\hline Nicaragua & 29 & 25 & 913 & 36 & 24 & 832 & 3.5 & - & \\
\hline Algeria & 30 & 63 & 2272 & 65 & 45 & 1321 & 3.9 & - & \\
\hline \multirow[t]{2}{*}{ Canada } & 31 & 418 & 15484 & 114 & 272 & 6288 & 10.8 & 61 & SARS \\
\hline & \multicolumn{7}{|c|}{ Other countries with success until Oct. 2020} & & \\
\hline Slovak Republic & 69 & 392 & 32885 & 19 & 40 & 10562 & 9.2 & 22 & \\
\hline Slovenia & 150 & 1297 & 58757 & 30 & 163 & 16502 & 12.9 & 33 & \\
\hline Lithuania & 94 & 660 & 52145 & 4 & 56 & 5442 & 13.8 & 19 & \\
\hline Austria & 102 & 691 & 40062 & 21 & 123 & 11650 & 13.7 & 42 & \\
\hline Georgia & 115 & 628 & 57009 & 23 & 77 & 9760 & 10.2 & - & \\
\hline Croatia & 132 & 955 & 51358 & 26 & 133 & 12013 & 13.1 & 54 & \\
\hline \multicolumn{10}{|c|}{ Other countries in top third of Lowy's Covid Performance Index } \\
\hline Rwanda & 64 & 7 & 647 & 53 & 3 & 397 & 1.6 & 6 & \\
\hline Malta & 63 & 496 & 28931 & 32 & 140 & 13684 & 11.3 & 14 & \\
\hline Togo & 76 & 8 & 439 & 73 & 7 & 282 & 1.5 & 15 & \\
\hline Tunisia & 119 & 396 & 11773 & 100 & 111 & 5061 & 5.1 & 21 & \\
\hline Myanmar & 41 & 49 & 2291 & 41 & 23 & 969 & 3.1 & 24 & \\
\hline Mozambique & 53 & 5 & 596 & 45 & 3 & 412 & 1.9 & 26 & \\
\hline Malawi & 61 & 10 & 344 & 64 & 10 & 310 & 1.8 & 27 & \\
\hline Zambia & 89 & 21 & 1127 & 87 & 19 & 894 & 1.5 & 29 & \\
\hline Uganda & 86 & 5 & 770 & 69 & 2 & 273 & 1.3 & 30 & \\
\hline \multicolumn{10}{|c|}{ Other countries with past recent epidemics } \\
\hline Congo, Democratic Republic of & 59 & 7 & 197 & 49 & 3 & 126 & 1.7 & 39 & Ebola \\
\hline Guinea & 60 & 6 & 1045 & 56 & 5 & 919 & 1.7 & - & Ebola \\
\hline Liberia & 71 & 16 & 352 & 83 & 16 & 282 & 1.8 & - & Ebola \\
\hline Sierra Leone & 91 & 10 & 327 & 84 & 9 & 297 & 1.3 & - & Ebola \\
\hline United Arab Emirates & 108 & 68 & 21013 & 107 & 50 & 13410 & 0.5 & 35 & MERS \\
\hline Saudi Arabia & 114 & 179 & 10419 & 119 & 155 & 9975 & 1.8 & 64 & MERS \\
\hline
\end{tabular}

This table presents the top-30 countries with lowest age-adjusted mortality rates in 2020, as well as rankings as of October 2020, and the top one-third of countries ranked according to Lowy's Covid-19 Performance Index. 
Figure 3: Covid-19 Incidence: Containment by Success Groups
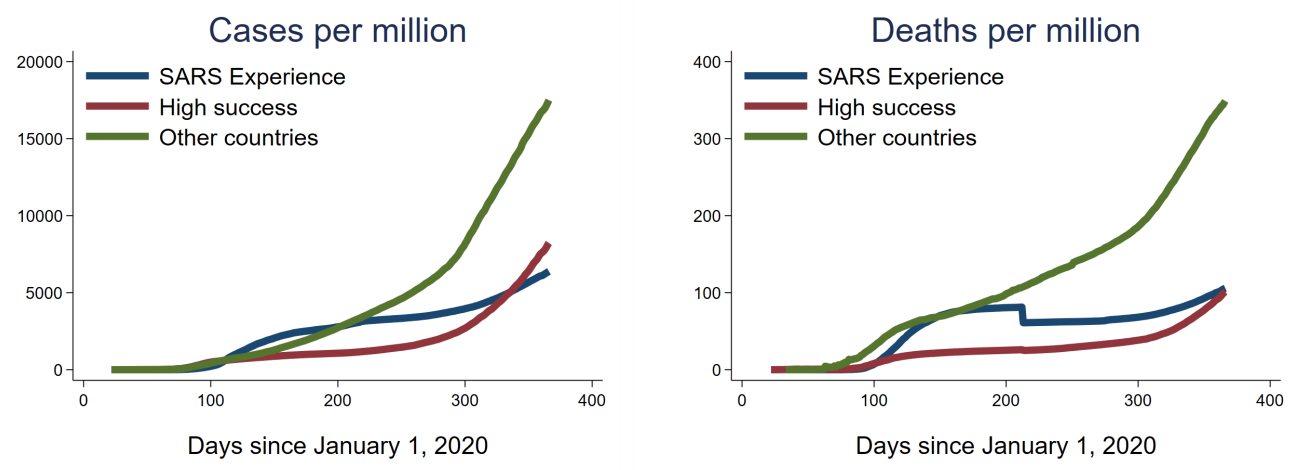

Figure 4: Timeline of Containment Policies: Learning from Countries with Past SARS Experience
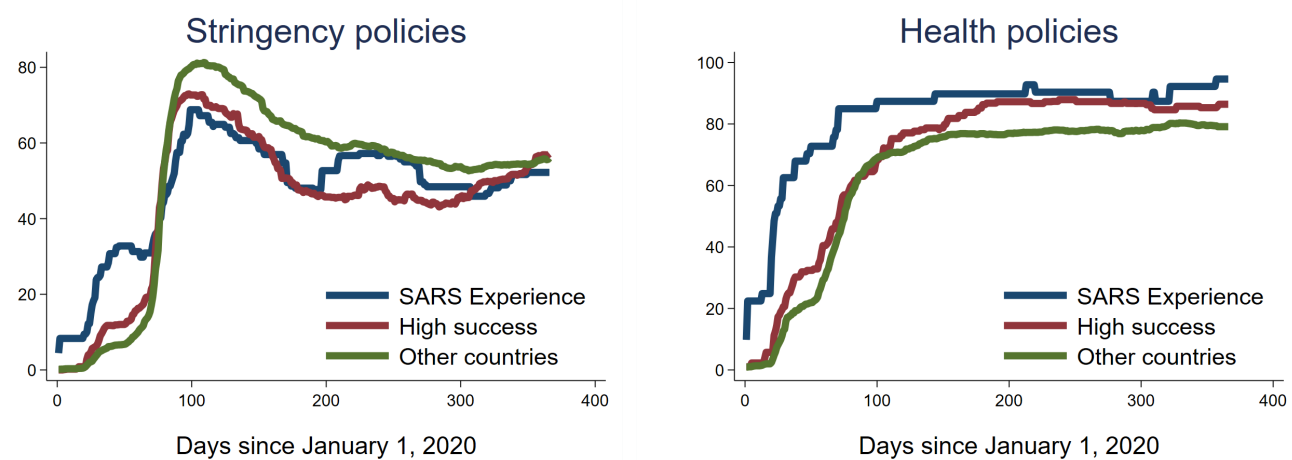

Stringency policies

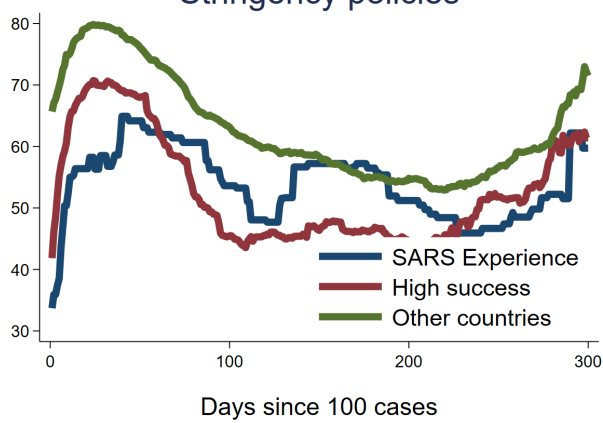

Health policies

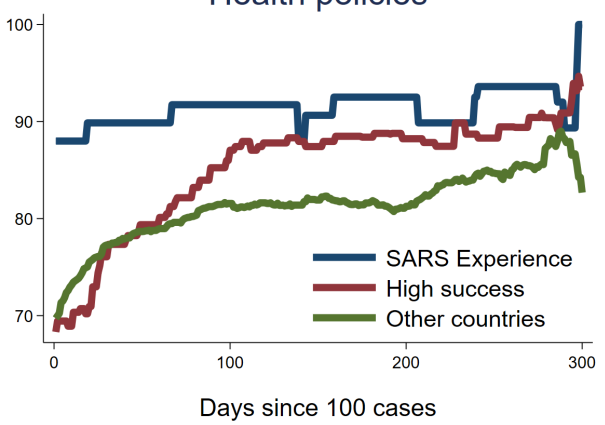


Figure 5: Timeline of Containment Measures, by Containment Success Groups

Countries with past SARS experience enacted earlier with stronger health policies (public information campaigns, testing, and contact tracing) ...
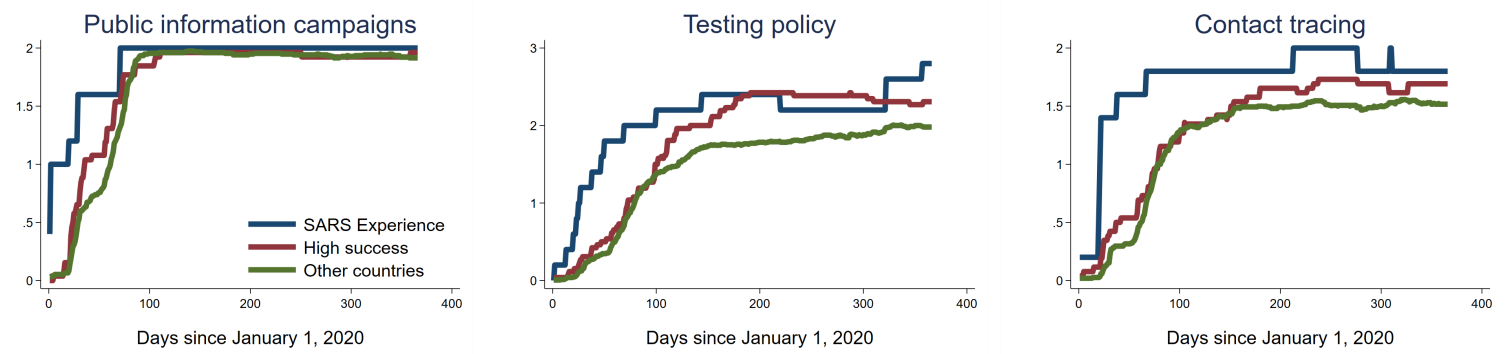

... and earlier restrictive measures such as international travel controls, school closures, and public

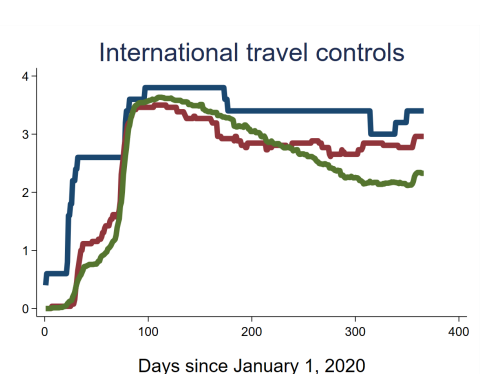
event cancellations.
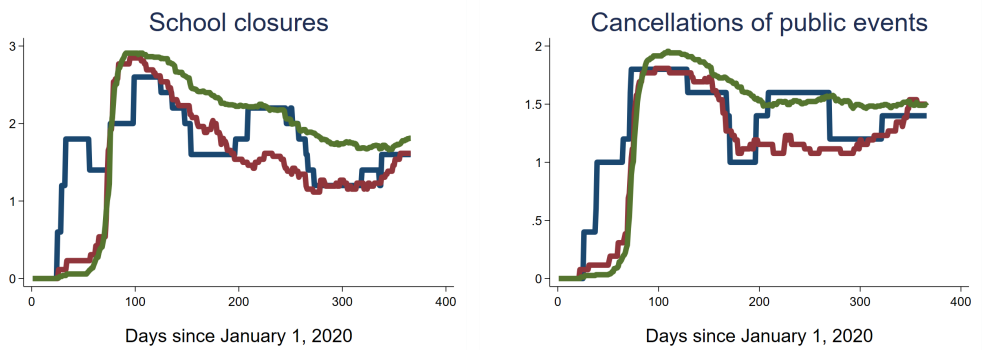

Yet, policies limiting mobility and gatherings of people (e.g. stay-at-home orders, workplace and transport closures, internal mobility and gathering restrictions) and mask requirements were not

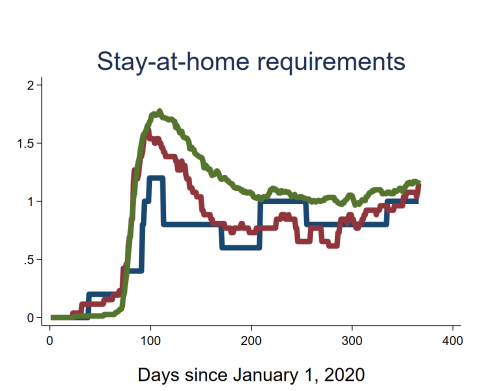
enacted earlier nor stricter.
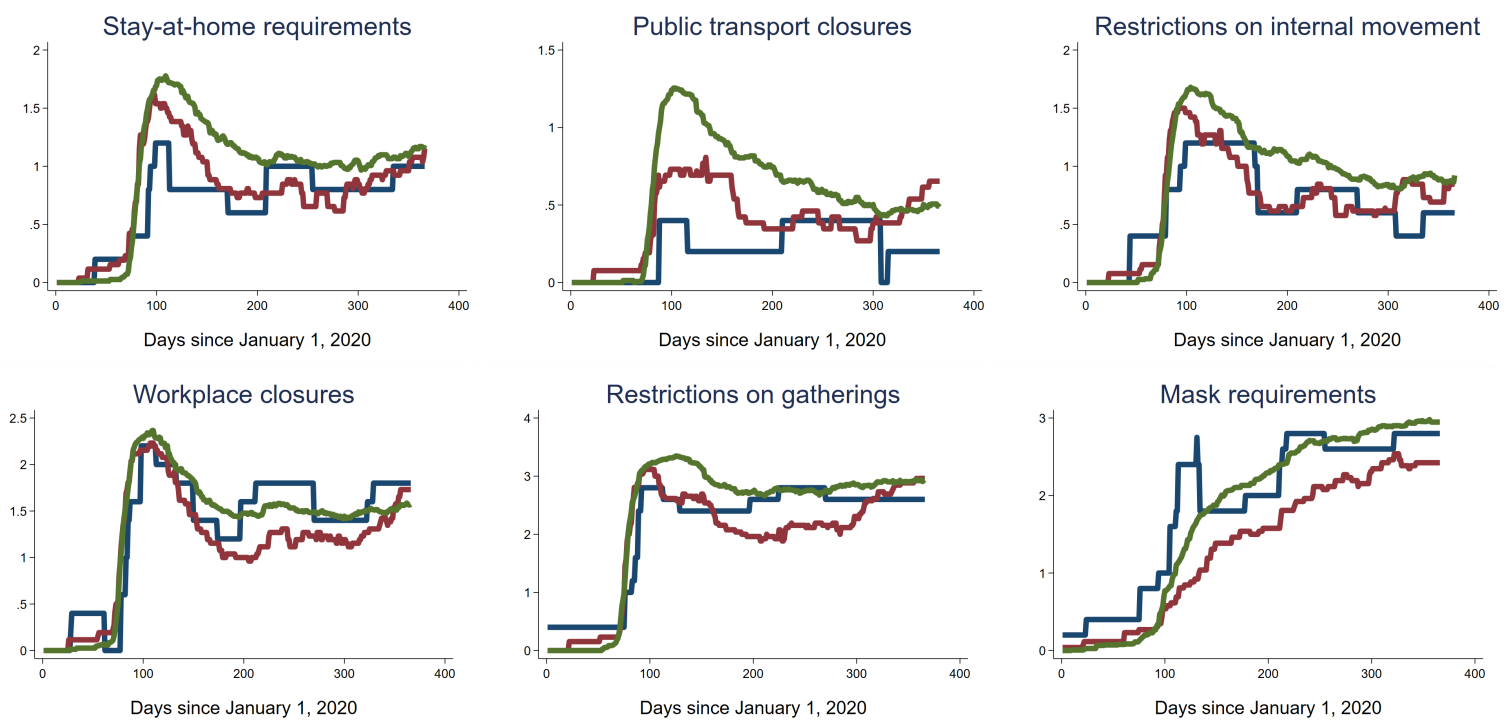

Source: OxCGRT Database and authors' calculations. 
Figure 6: Apple Mobility Trends: Walking and Driving Behavior

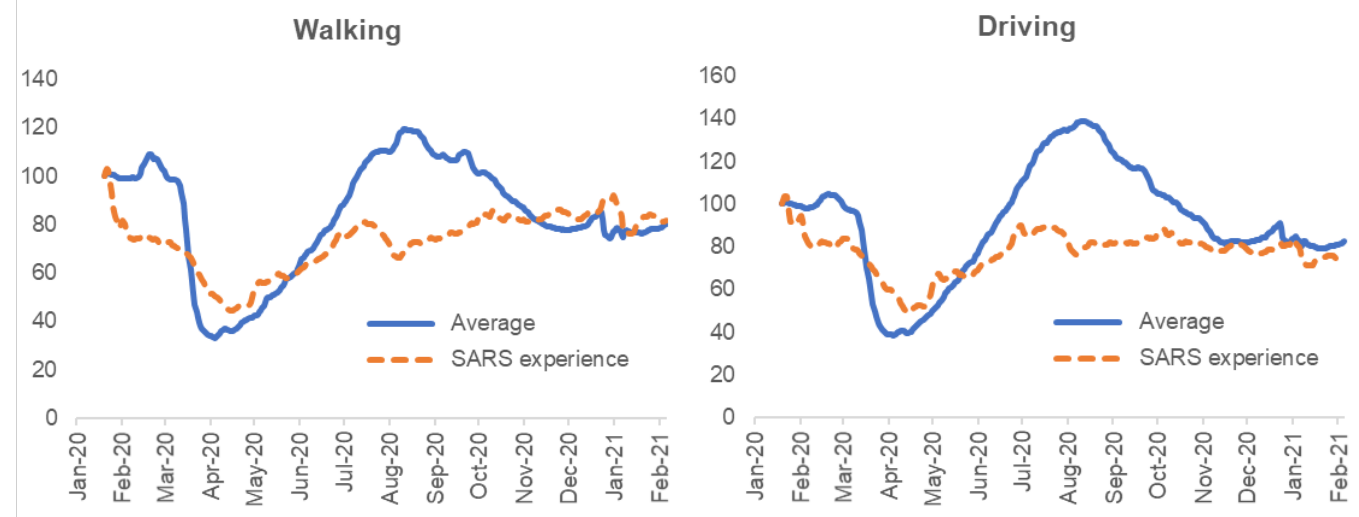

Figure 7: Vietnam (Early Stringency) vs. Philippines (Delayed Stringency)

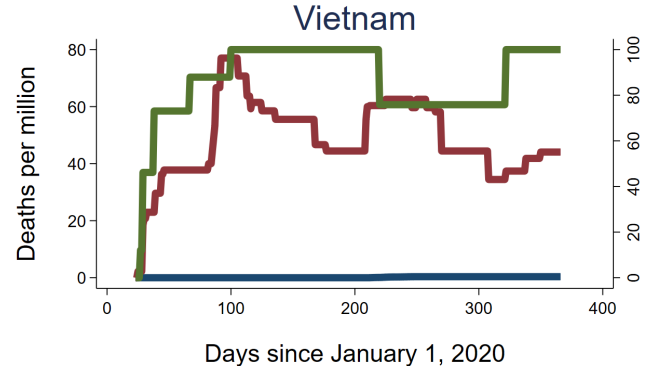

Deaths per million $\quad$ Stringency (rhs) Health policies (rhs)

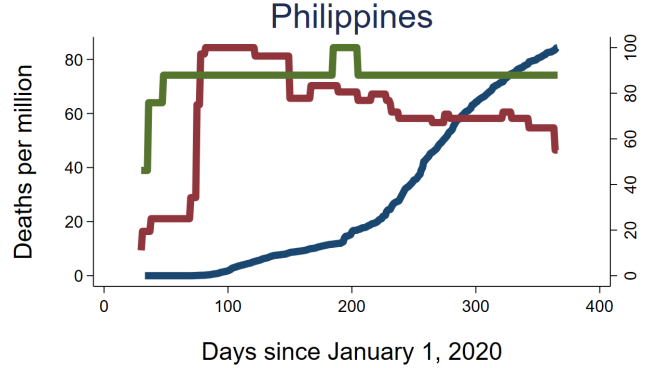

Deaths per million Stringency (rhs) 
Figure 8: Containment Measures Since 100 Cases: Countries with Past SARS Experience

At the time of 100 positive cases, countries with past SARS experience already had stronger health policies (public information campaigns, testing, and contact tracing) ...
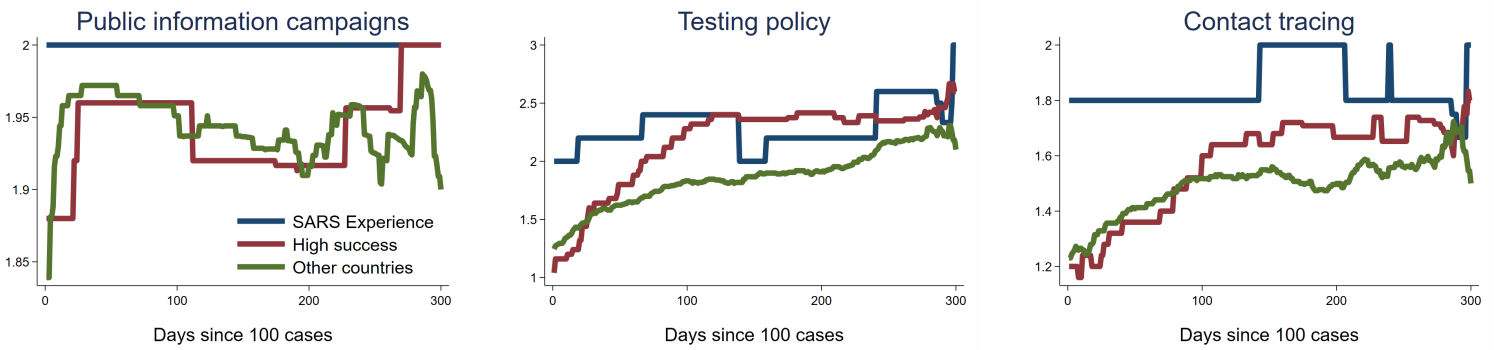

... but not tighter restrictive measures such as international travel controls, school closures, and public event cancellations ...
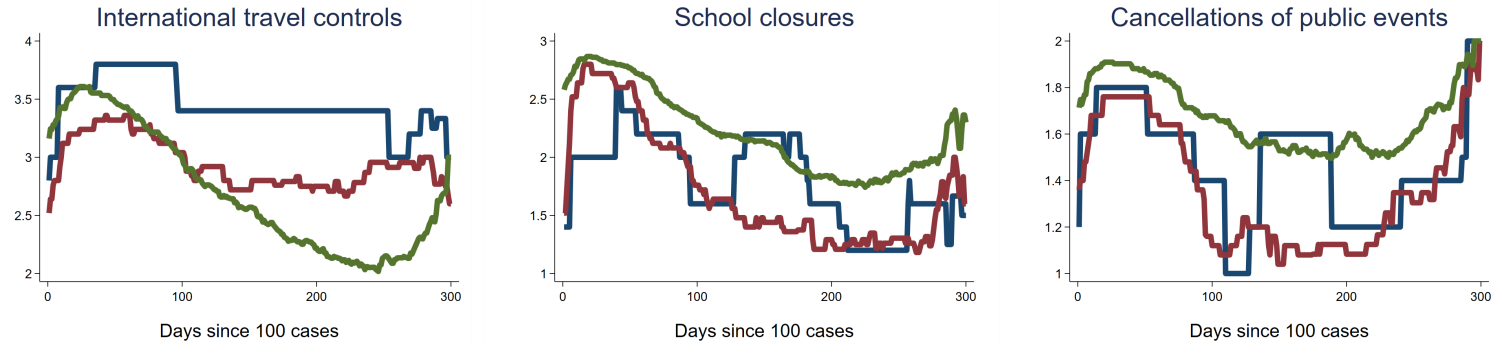

... nor stronger policies limiting mobility and gatherings of people (e.g. stay-at-home orders, workplace and transport closures, internal mobility and gathering restrictions) and mask requirements.
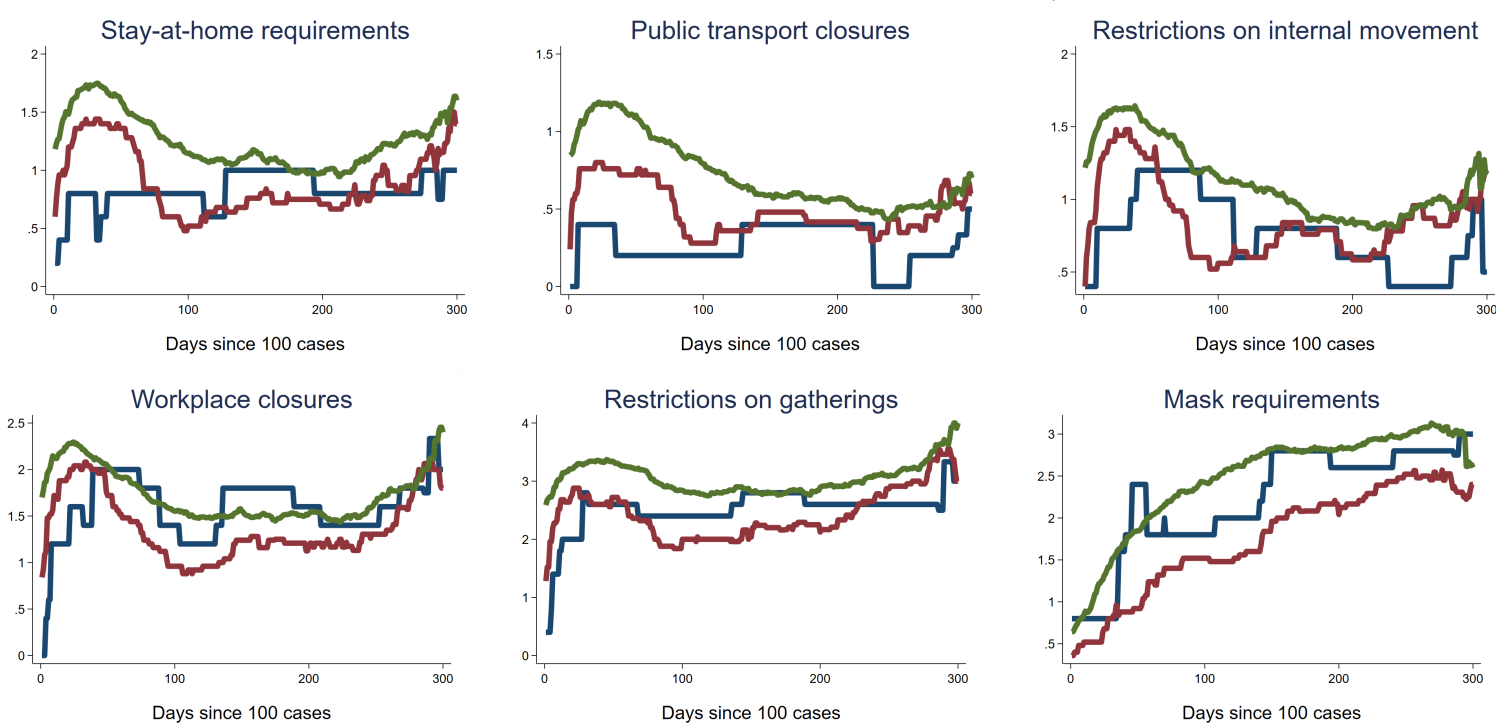

Source: OxCGRT Database and authors' calculations. 
Figure 9: Timeline of Containment Measures, by 1st Wave Containment Success Groups

Countries with past SARS experience enacted earlier and stronger health policies (public information campaigns, testing, and contact tracing) ...
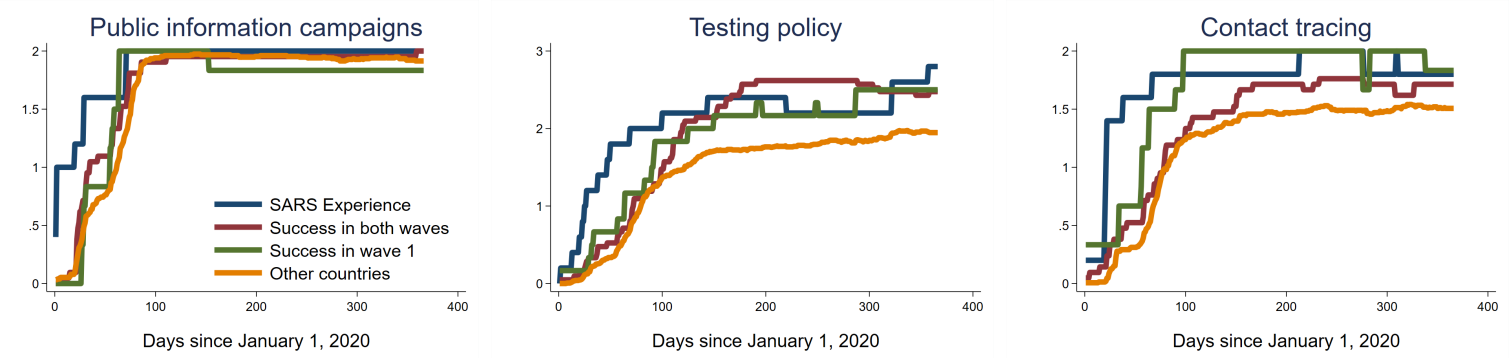

... and earlier restrictive measures such as international travel controls, school closures, and public

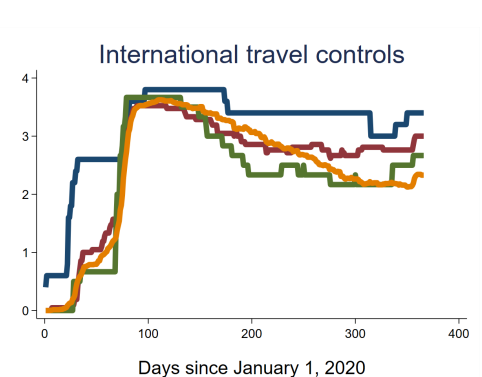
event cancellations.
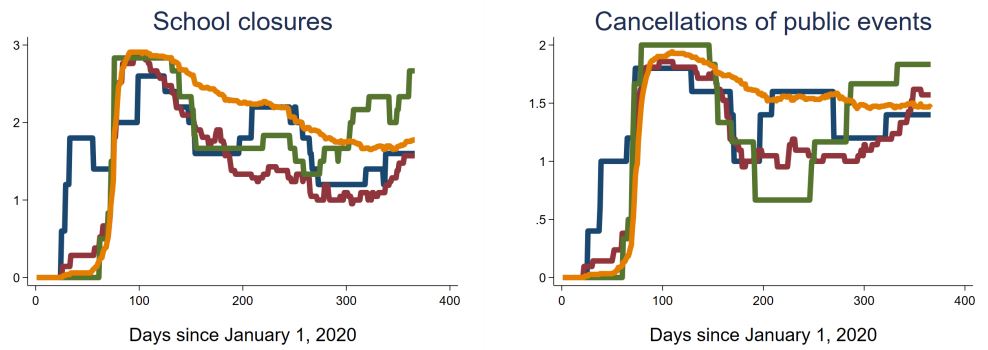

Yet, policies limiting mobility and gatherings of people (e.g. stay-at-home orders, workplace and transport closures, internal mobility and gathering restrictions) and mask requirements were not

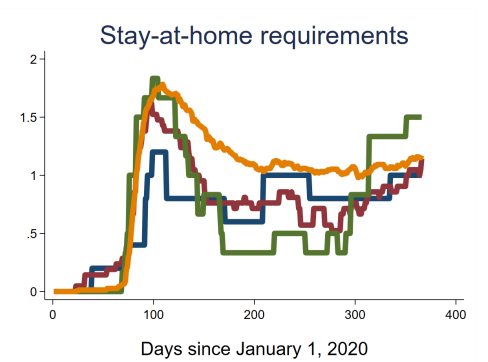
enacted earlier nor stricter.
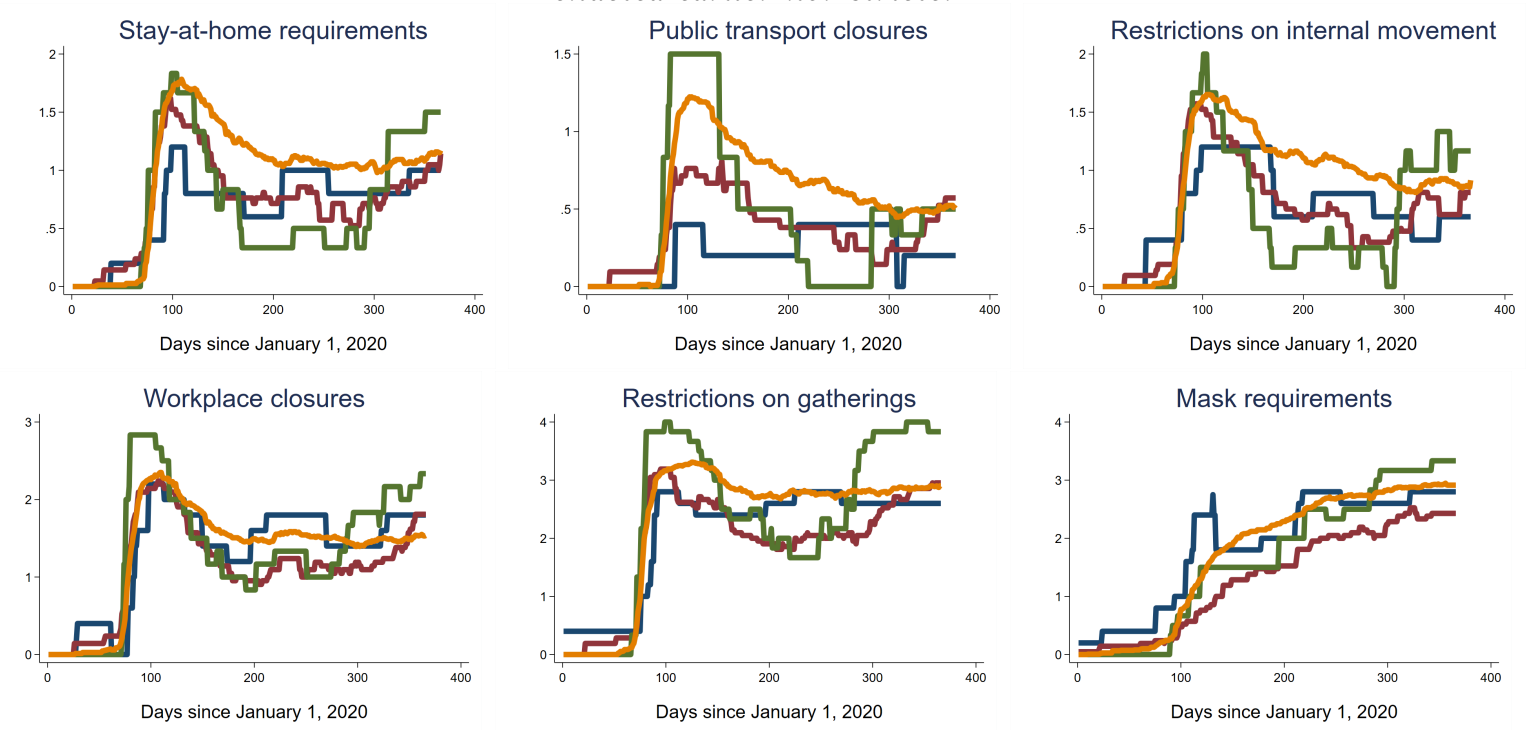

Source: OxCGRT Database and authors' calculations. 
Figure 10: Containment Measures by Income Group
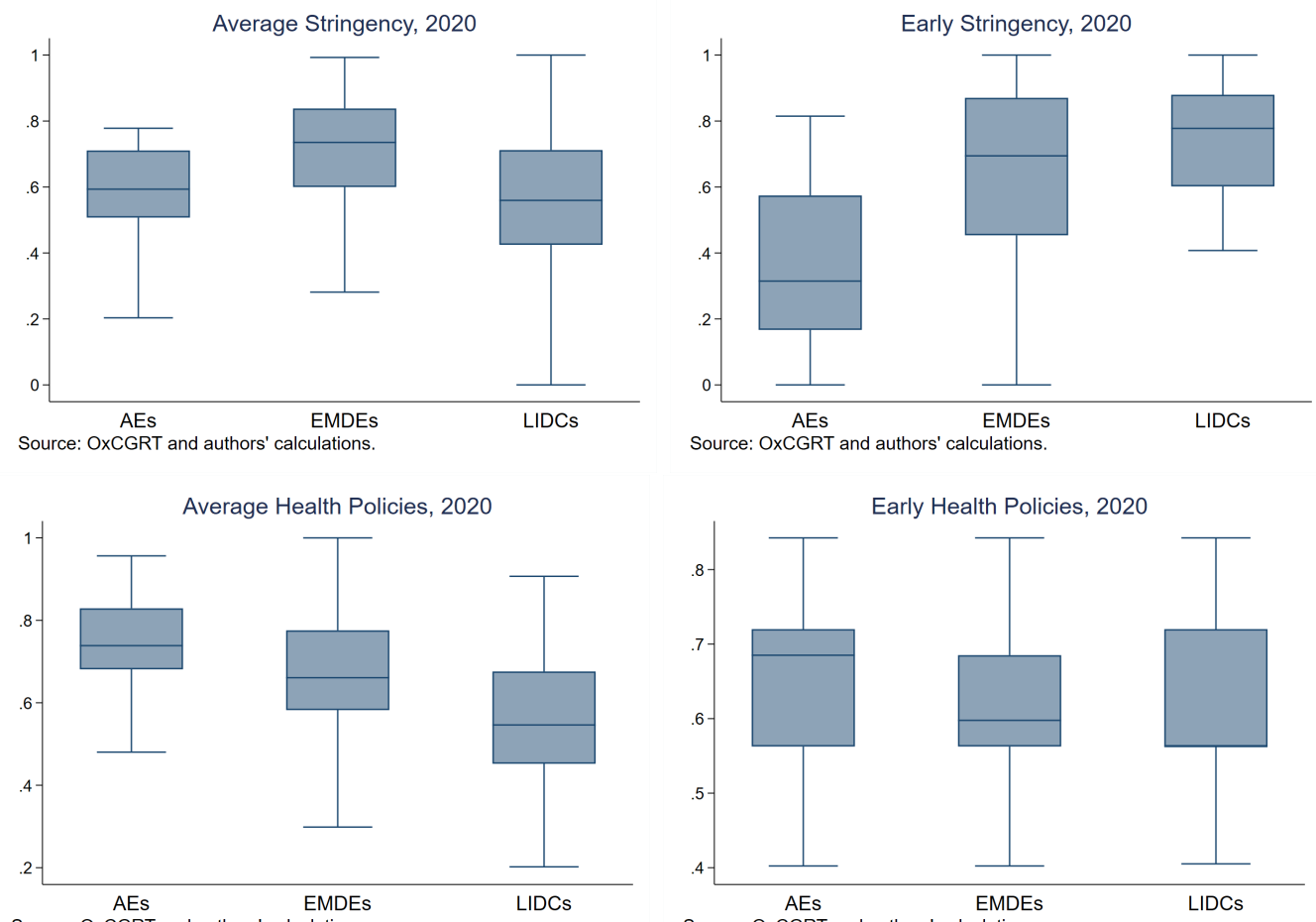

Source: OxCGRT and authors' calculations.

Source: OxES

Figure 11: WEO Growth Revisions by Income Group
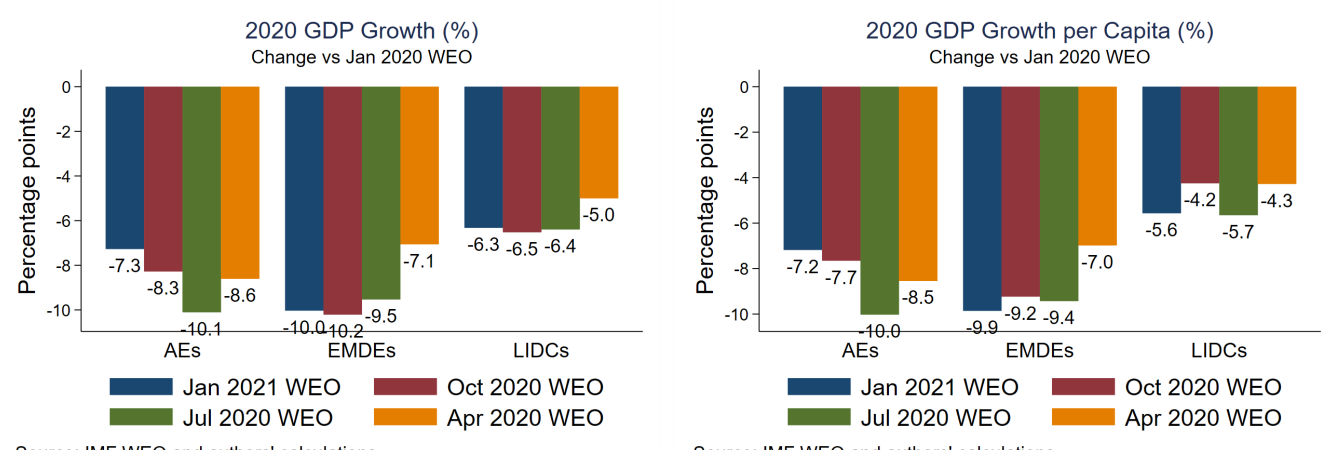

Source: IMF WEO and authors' calculations.

Figure 12: WEO Fiscal Position Revisions by Income Group
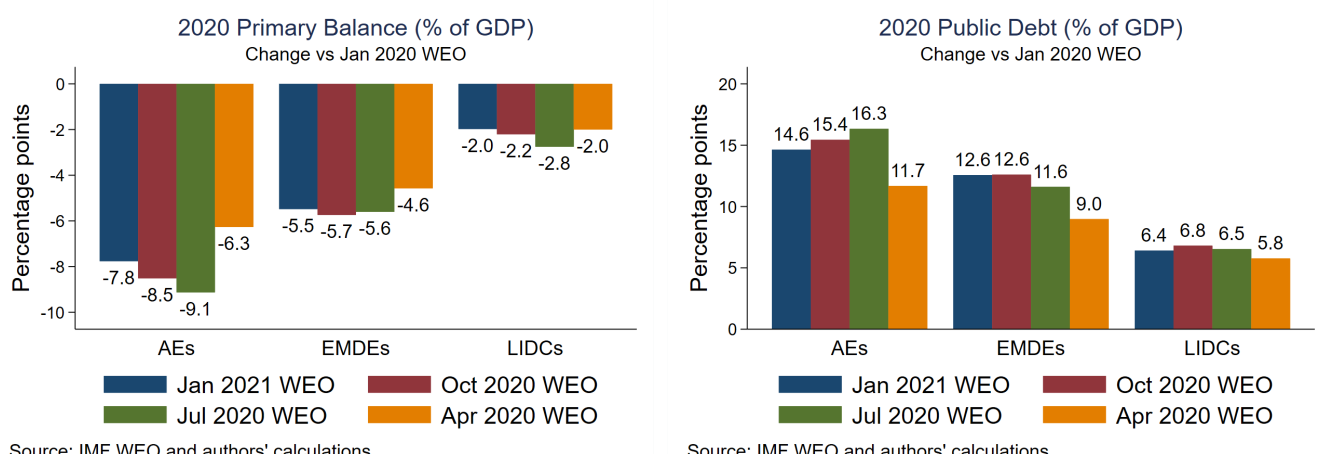

Source: IMF WEO and authors' calculations. 
Figure 13: Covid-19 Fiscal Support Measures by Income Group

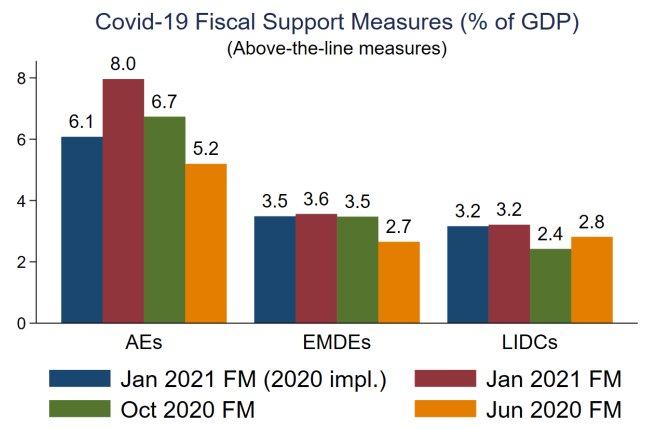

Source: IMF Fiscal Monitor (FM) and authors' calculations.

Table 2: Effect of Containment Measures - Average vs. Early Response, 2020 by Month

\begin{tabular}{|c|c|c|c|c|c|c|c|c|c|}
\hline & $\begin{array}{c}1) \\
\text { Apr. } \\
\text { Deaths/pop }\end{array}$ & $\begin{array}{c}(2) \\
\text { May } \\
\text { Deaths/pop }\end{array}$ & $\begin{array}{c}(3) \\
\text { Jun. } \\
\text { Deaths/pop }\end{array}$ & $\begin{array}{c}(4) \\
\text { Jul. } \\
\text { Deaths/pop } \\
\end{array}$ & $\begin{array}{c}\text { (5) } \\
\text { Aug. } \\
\text { Deaths/pop }\end{array}$ & $\begin{array}{c}(6) \\
\text { Sep. } \\
\text { Deaths/pop }\end{array}$ & $\begin{array}{c}(7) \\
\text { Oct. } \\
\text { Deaths/pop }\end{array}$ & $\begin{array}{c}(8) \\
\text { Nov. } \\
\text { Deaths/pop }\end{array}$ & $\begin{array}{c}9) \\
\text { Dec. } \\
\text { Deaths/pop }\end{array}$ \\
\hline Containment (average) & $\begin{array}{l}101.884 \\
(81.086)\end{array}$ & $\begin{array}{l}140.769 \\
(93.272)\end{array}$ & $\begin{array}{c}223.482^{* *} \\
(95.011)\end{array}$ & $\begin{array}{c}315.315^{* * * *} \\
(97.842)\end{array}$ & $\begin{array}{c}408.270^{* * * *} \\
(106.272)\end{array}$ & $\begin{array}{c}467.717^{* * *} \\
(115.267)\end{array}$ & $\begin{array}{c}518.729^{* * * *} \\
(128.018)\end{array}$ & $\begin{array}{c}543.993^{* * *} \\
(158.775)\end{array}$ & $\begin{array}{c}539.886 * * * \\
(197.570)\end{array}$ \\
\hline Containment (at 100 cases) & $\begin{array}{l}-77.058^{*} \\
(40.723)\end{array}$ & $\begin{array}{c}-124.338^{* * *} \\
(52.838)\end{array}$ & $\begin{array}{c}-187.242^{* * * *} \\
(56.464)\end{array}$ & $\begin{array}{c}-229.402^{* * * *} \\
(62.270)\end{array}$ & $\begin{array}{c}-252.951 * * * \\
(70.726)\end{array}$ & $\begin{array}{c}-253.912^{* * * *} \\
(79.887)\end{array}$ & $\begin{array}{c}-244.617^{* * * *} \\
(89.327)\end{array}$ & $\begin{array}{l}-206.642^{*} \\
(109.412)\end{array}$ & $\begin{array}{l}-161.650 \\
(134.740)\end{array}$ \\
\hline Median age & $\begin{array}{l}3.684^{*} \\
(1.987)\end{array}$ & $\begin{array}{l}4.685^{*} \\
(2.462)\end{array}$ & $\begin{array}{l}5.197^{*} \\
(2.683)\end{array}$ & $\begin{array}{l}5.106^{*} \\
(3.044)\end{array}$ & $\begin{array}{c}5.499 \\
(3.523)\end{array}$ & $\begin{array}{c}6.583 \\
(4.016)\end{array}$ & $\begin{array}{c}9.093^{* *} \\
(4.529)\end{array}$ & $\begin{array}{c}19.211^{* * * *} \\
(5.570)\end{array}$ & $\begin{array}{c}32.186^{* * * *} \\
(6.790)\end{array}$ \\
\hline Hospital beds / 1,000 population & $\begin{array}{c}-9.127^{* *} \\
(4.531)\end{array}$ & $\begin{array}{c}-11.870^{* *} \\
(5.639)\end{array}$ & $\begin{array}{c}-13.014^{* *} \\
(6.155)\end{array}$ & $\begin{array}{c}-12.567^{*} \\
(7.051)\end{array}$ & $\begin{array}{l}-12.783 \\
(8.130)\end{array}$ & $\begin{array}{l}-14.083 \\
(9.235)\end{array}$ & $\begin{array}{c}-13.872 \\
(10.383)\end{array}$ & $\begin{array}{c}-15.771 \\
(12.772)\end{array}$ & $\begin{array}{l}-19.613 \\
(15.373)\end{array}$ \\
\hline Log GDP per capita & $\begin{array}{l}-7.581 \\
(15.993)\end{array}$ & $\begin{array}{c}-9.631 \\
(19.565)\end{array}$ & $\begin{array}{l}-12.902 \\
(21.495)\end{array}$ & $\begin{array}{l}-20.288 \\
(24.638)\end{array}$ & $\begin{array}{l}-29.815 \\
(28.426)\end{array}$ & $\begin{array}{l}-41.427 \\
(32.292)\end{array}$ & $\begin{array}{l}-53.817 \\
(36.320)\end{array}$ & $\begin{array}{c}-93.923^{* *} \\
(44.579)\end{array}$ & $\begin{array}{c}-134.268^{* *} \\
(54.160)\end{array}$ \\
\hline EMDEs & $\begin{array}{c}-87.784^{* * * *} \\
(26.245)\end{array}$ & $\begin{array}{c}-104.111^{* * * *} \\
(32.378)\end{array}$ & $\begin{array}{c}-84.523^{* * *} \\
(35.409)\end{array}$ & $\begin{array}{c}-64.321 \\
(40.375)\end{array}$ & $\begin{array}{c}-43.398 \\
(46.620)\end{array}$ & $\begin{array}{l}-25.288 \\
(52.934)\end{array}$ & $\begin{array}{l}-12.785 \\
(59.514)\end{array}$ & $\begin{array}{l}-21.232 \\
(73.203)\end{array}$ & $\begin{array}{l}-24.388 \\
(90.340)\end{array}$ \\
\hline LIDCs & $\begin{array}{c}-67.461 \\
(49.323)\end{array}$ & $\begin{array}{c}-81.549 \\
(60.296)\end{array}$ & $\begin{array}{c}-67.597 \\
(65.581)\end{array}$ & $\begin{array}{c}-76.397 \\
(73.046)\end{array}$ & $\begin{array}{c}-91.706 \\
(84.350)\end{array}$ & $\begin{array}{r}-113.436 \\
(95.942)\end{array}$ & $\begin{array}{c}-129.404 \\
(108.097)\end{array}$ & $\begin{array}{c}-173.067 \\
(133.317)\end{array}$ & $\begin{array}{c}-206.126 \\
(164.812)\end{array}$ \\
\hline Constant & $\begin{array}{l}28.731 \\
(79.067)\end{array}$ & $\begin{array}{l}36.871 \\
(96.775)\end{array}$ & $\begin{array}{c}17.934 \\
(106.758)\end{array}$ & $\begin{array}{c}18.283 \\
(119.868)\end{array}$ & $\begin{array}{c}1.281 \\
(139.269)\end{array}$ & $\begin{array}{c}-26.082 \\
(159.798)\end{array}$ & $\begin{array}{c}-89.198 \\
(181.531)\end{array}$ & $\begin{array}{l}-256.555 \\
(224.674)\end{array}$ & $\begin{array}{l}-482.233^{*} \\
(277.924)\end{array}$ \\
\hline Observations & 127 & 132 & 132 & 134 & 134 & 134 & 134 & 134 & 136 \\
\hline R-squared & 0.337 & 0.340 & 0.328 & 0.284 & 0.266 & 0.260 & 0.268 & 0.316 & 0.380 \\
\hline
\end{tabular}

Table 3: Effect of Containment Measures - Stringency vs Health Policies, 2020 by Month

\begin{tabular}{|c|c|c|c|c|c|c|c|c|c|}
\hline & $\begin{array}{c}(1) \\
\text { Apr. } \\
\text { Deaths/pop }\end{array}$ & $\begin{array}{c}(2) \\
\text { May } \\
\text { Deaths/pop }\end{array}$ & $\begin{array}{c}(3) \\
\text { Jun. } \\
\text { Deaths/pop }\end{array}$ & $\begin{array}{c}(4) \\
\text { Jul. } \\
\text { Deaths/pop }\end{array}$ & $\begin{array}{c}\text { (5) } \\
\text { Aug. } \\
\text { Deaths/pop }\end{array}$ & $\begin{array}{c}(6) \\
\text { Sep. } \\
\text { Deaths/pop }\end{array}$ & $\begin{array}{c}(7) \\
\text { Oct. } \\
\text { Deaths/pop }\end{array}$ & $\begin{array}{c}(8) \\
\text { Nov. } \\
\text { Deaths/pop }\end{array}$ & $\begin{array}{c}(9) \\
\text { Dec. } \\
\text { Deaths/pop }\end{array}$ \\
\hline Stringency (average) & $\begin{array}{c}278.327^{* * * *} \\
(93.063)\end{array}$ & $\begin{array}{c}324.611^{* * *} \\
(97.963)\end{array}$ & $\begin{array}{c}368.228^{* * * *} \\
(93.180)\end{array}$ & $\begin{array}{c}453.853^{* * *} \\
(92.246)\end{array}$ & $\begin{array}{c}539.422^{* * * *} \\
(97.573)\end{array}$ & $\begin{array}{c}603.174^{* * * *} \\
(102.366)\end{array}$ & $\begin{array}{c}665.827^{* * * *} \\
(112.687)\end{array}$ & $\begin{array}{c}703.852^{* * *} \\
(141.872)\end{array}$ & $\begin{array}{c}682.713^{* * * *} \\
(176.121)\end{array}$ \\
\hline Health policies (average) & $\begin{array}{c}-172.993^{* *} \\
(81.060)\end{array}$ & $\begin{array}{c}-241.285^{* *} \\
(106.217)\end{array}$ & $\begin{array}{c}-259.753^{* * *} \\
(124.504)\end{array}$ & $\begin{array}{c}-319.352^{* *} \\
(146.516)\end{array}$ & $\begin{array}{c}-358.873^{* *} \\
(170.177)\end{array}$ & $\begin{array}{c}-388.658^{* *} \\
(188.466)\end{array}$ & $\begin{array}{c}-435.432 * * \\
(206.574)\end{array}$ & $\begin{array}{c}-505.430 * * \\
(251.480)\end{array}$ & $\begin{array}{c}-513.122^{*} \\
(302.976)\end{array}$ \\
\hline Stringency (at 100 cases) & $\begin{array}{c}-135.801 * * * \\
(42.304)\end{array}$ & $\begin{array}{c}-193.368^{* * * *} \\
(53.796)\end{array}$ & $\begin{array}{c}-222.077^{* * * *} \\
(55.913)\end{array}$ & $\begin{array}{c}-229.871^{* * * *} \\
(59.796)\end{array}$ & $\begin{array}{c}-222.917^{* * * *} \\
(66.070)\end{array}$ & $\begin{array}{c}-196.508^{* * * *} \\
(72.262)\end{array}$ & $\begin{array}{c}-179.157^{* *} \\
(80.058)\end{array}$ & $\begin{array}{l}-147.972 \\
(100.061)\end{array}$ & $\begin{array}{c}-92.057 \\
(125.434)\end{array}$ \\
\hline Health policies (at 100 cases) & $\begin{array}{c}68.694 \\
(66.560)\end{array}$ & $\begin{array}{c}80.589 \\
(84.515)\end{array}$ & $\begin{array}{c}28.796 \\
(93.968)\end{array}$ & $\begin{array}{c}-28.915 \\
(106.406)\end{array}$ & $\begin{array}{c}-80.928 \\
(119.973)\end{array}$ & $\begin{array}{l}-140.833 \\
(131.239)\end{array}$ & $\begin{array}{l}-142.806 \\
(144.643)\end{array}$ & $\begin{array}{c}-97.402 \\
(178.684)\end{array}$ & $\begin{array}{l}-108.476 \\
(222.142)\end{array}$ \\
\hline Controls: & & & & & & & & & \\
\hline Median age & $\begin{array}{l}3.560^{*} \\
(1.953)\end{array}$ & $\begin{array}{l}4.278^{*} \\
(2.411)\end{array}$ & $\begin{array}{l}5.056^{*} \\
(2.603)\end{array}$ & $\begin{array}{l}5.213^{*} \\
(2.900)\end{array}$ & $\begin{array}{l}5.510^{*} \\
(3.321)\end{array}$ & $\begin{array}{l}6.342^{*} \\
(3.729)\end{array}$ & $\begin{array}{l}8.712^{* *} \\
(4.201)\end{array}$ & $\begin{array}{c}18.402 * * * \\
(5.283)\end{array}$ & $\begin{array}{c}30.665^{* * *} \\
(6.576)\end{array}$ \\
\hline Hospital beds / 1,000 population & $\begin{array}{l}-7.532^{*} \\
(4.449)\end{array}$ & $\begin{array}{l}-7.644 \\
(5.643)\end{array}$ & $\begin{array}{l}-8.517 \\
(6.112)\end{array}$ & $\begin{array}{l}-7.439 \\
(6.853)\end{array}$ & $\begin{array}{l}-7.022 \\
(7.806)\end{array}$ & $\begin{array}{l}-7.412 \\
(8.736)\end{array}$ & $\begin{array}{l}-6.099 \\
(9.829)\end{array}$ & $\begin{array}{c}-6.805 \\
(12.392)\end{array}$ & $\begin{array}{l}-10.486 \\
(15.224)\end{array}$ \\
\hline Log GDP per capita & $\begin{array}{c}-6.696 \\
(16.022)\end{array}$ & $\begin{array}{c}-4.396 \\
(19.462)\end{array}$ & $\begin{array}{c}-0.830 \\
(21.314)\end{array}$ & $\begin{array}{c}4.734 \\
(24.201)\end{array}$ & $\begin{array}{c}5.040 \\
(27.766)\end{array}$ & $\begin{array}{c}1.885 \\
(31.137)\end{array}$ & $\begin{array}{c}-5.465 \\
(35.052)\end{array}$ & $\begin{array}{l}-41.205 \\
(44.138)\end{array}$ & $\begin{array}{l}-73.454 \\
(54.961)\end{array}$ \\
\hline EMDE dummy & $\begin{array}{c}-86.129^{* * * *} \\
(25.722)\end{array}$ & $\begin{array}{c}-104.652^{* * *} \\
(31.727)\end{array}$ & $\begin{array}{c}-92.751^{* * * *} \\
(34.570)\end{array}$ & $\begin{array}{c}-80.450^{* * *} \\
(38.637)\end{array}$ & $\begin{array}{l}-68.553 \\
(44.214)\end{array}$ & $\begin{array}{l}-60.216 \\
(49.539)\end{array}$ & $\begin{array}{l}-50.220 \\
(55.663)\end{array}$ & $\begin{array}{l}-57.380 \\
(69.995)\end{array}$ & $\begin{array}{l}-57.680 \\
(88.035)\end{array}$ \\
\hline LIDC dummy & $\begin{array}{l}-53.460 \\
(48.503)\end{array}$ & $\begin{array}{l}-62.430 \\
(58.789)\end{array}$ & $\begin{array}{l}-53.793 \\
(63.404)\end{array}$ & $\begin{array}{l}-55.946 \\
(69.322)\end{array}$ & $\begin{array}{l}-72.409 \\
(79.243)\end{array}$ & $\begin{array}{l}-95.887 \\
(88.962)\end{array}$ & $\begin{array}{l}-112.430 \\
(100.277)\end{array}$ & $\begin{array}{l}-154.817 \\
(126.532)\end{array}$ & $\begin{array}{l}-182.595 \\
(159.704)\end{array}$ \\
\hline Constant & $\begin{array}{c}-9.708 \\
(79.958)\end{array}$ & $\begin{array}{c}5.234 \\
(97.221)\end{array}$ & $\begin{array}{c}14.289 \\
(106.204)\end{array}$ & $\begin{array}{c}32.923 \\
(117.042)\end{array}$ & $\begin{array}{c}44.752 \\
(135.005)\end{array}$ & $\begin{array}{c}55.762 \\
(153.134)\end{array}$ & $\begin{array}{c}17.016 \\
(173.492)\end{array}$ & $\begin{array}{l}-127.143 \\
(218.941)\end{array}$ & $\begin{array}{r}-333.030 \\
(275.242)\end{array}$ \\
\hline Observ & 127 & 132 & 132 & 134 & 134 & 134 & 134 & 134 & 136 \\
\hline R-squared & 0.382 & 0.391 & 0.386 & 0.367 & 0.363 & 0.376 & 0.383 & 0.396 & 0.431 \\
\hline
\end{tabular}


Table 4: Effect of Individual Containment Measures (One at a time), 2020

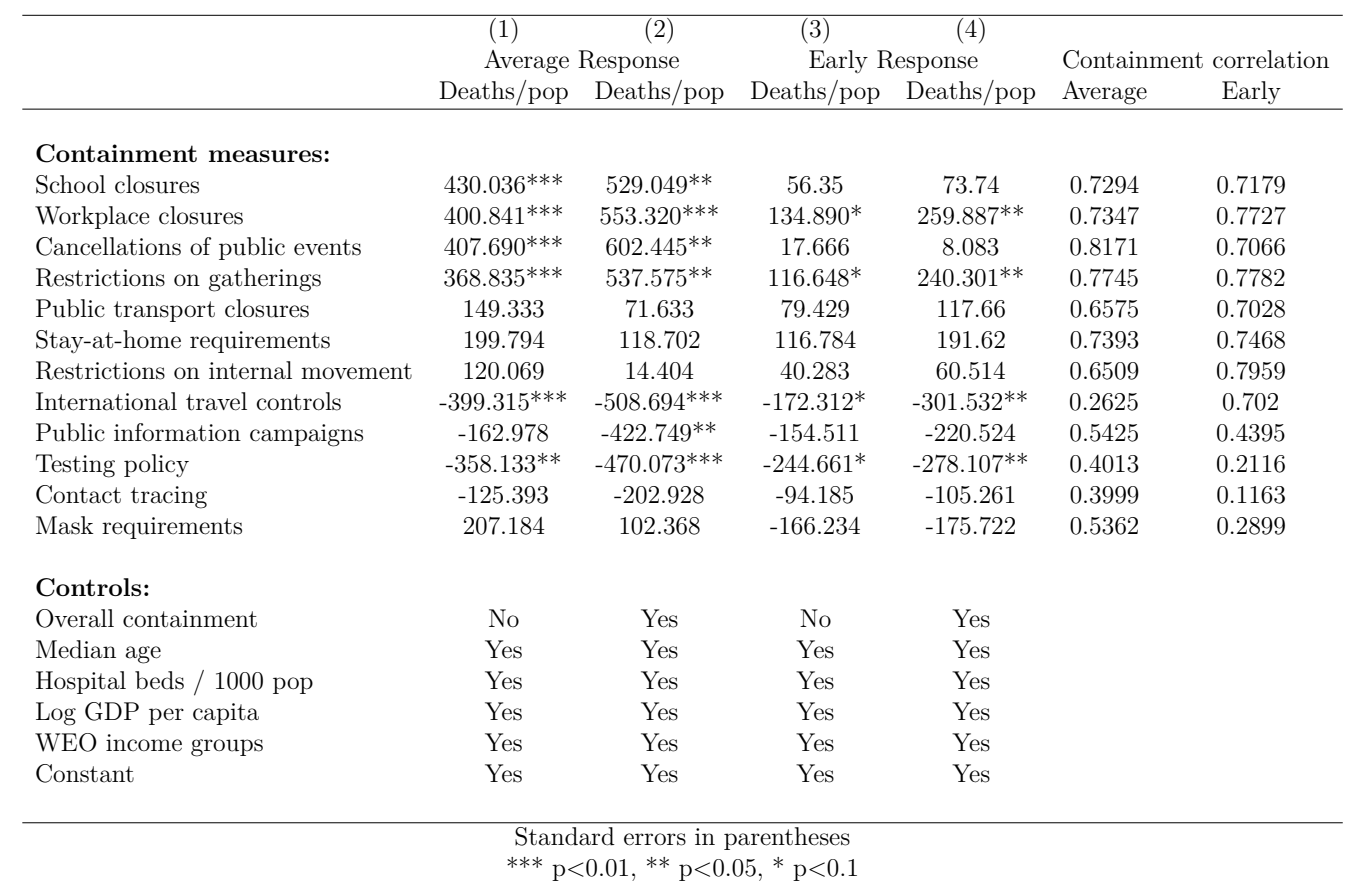

Table 5: $t$-Test for Difference in Containment Measures (One at a time), 2020

\begin{tabular}{|c|c|c|c|c|c|c|c|c|}
\hline & \multicolumn{4}{|c|}{ Average containment policies } & \multicolumn{4}{|c|}{ Early containment policies } \\
\hline & High success & Others & Diff. & $t$-statistic & High success & Others & Diff. & $t$-statistic \\
\hline Overall containment: & & & & & & & & \\
\hline Containment policies & 0.59 & 0.67 & $-0.078^{* *}$ & 2.33 & 0.39 & 0.61 & $-0.219^{* * *}$ & 4.43 \\
\hline Stringency & 0.55 & 0.67 & $-0.122^{\star \star \star \star}$ & 3.27 & 0.41 & 0.65 & $-0.240^{\star * *}$ & 4.46 \\
\hline Health policies & 0.72 & 0.62 & $0.096^{* * *}$ & -2.90 & 0.61 & 0.61 & 0.000 & 0.00 \\
\hline \multicolumn{9}{|l|}{ Individual policies: } \\
\hline School closures & 1.46 & 1.84 & $-0.384^{\star * \star *}$ & 3.91 & 1.50 & 2.55 & $-1.048^{* * *}$ & 4.55 \\
\hline Workplace closures & 1.16 & 1.35 & $-0.190^{*}$ & 1.84 & 0.75 & 1.66 & $-0.911^{* * *}$ & 3.84 \\
\hline Cancellations of public events & 1.13 & 1.36 & $-0.235^{\star * \star}$ & 3.44 & 1.29 & 1.72 & $-0.432^{\star \star \star}$ & 2.96 \\
\hline Restrictions on gatherings & 1.94 & 2.39 & $-0.451^{\star * * *}$ & 3.06 & 1.07 & 2.51 & $-1.437^{* * *}$ & 4.33 \\
\hline Public transport closures & 0.38 & 0.60 & $-0.218^{\star \star \star *}$ & 2.66 & 0.21 & 0.84 & $-0.624^{\star * *}$ & 3.59 \\
\hline Stay-at-home requirements & 0.76 & 0.99 & $-0.237^{\star \star}$ & 2.32 & 0.54 & 1.15 & $-0.618^{* * *}$ & 2.96 \\
\hline Restrictions on internal movem $€$ & 0.71 & 0.93 & $-0.218^{\star \star}$ & 2.33 & 0.43 & 1.21 & $-0.781^{\star * \star}$ & 4.15 \\
\hline International travel controls & 2.61 & 2.40 & $0.208^{\star \star}$ & -2.12 & 2.64 & 3.15 & $-0.510^{*}$ & 1.91 \\
\hline Public information campaigns & 1.72 & 1.67 & 0.057 & -1.36 & 1.89 & 1.85 & 0.046 & -0.47 \\
\hline Testing policy & 1.83 & 1.45 & $0.379^{* * *}$ & -3.56 & 1.18 & 1.23 & -0.047 & 0.35 \\
\hline Contact tracing & 1.38 & 1.21 & $0.165^{*}$ & -1.78 & 1.25 & 1.24 & 0.008 & -0.05 \\
\hline Mask requirements & 1.43 & 1.86 & $-0.429^{\star \star \star}$ & 3.39 & 0.32 & 0.63 & -0.311 & 1.37 \\
\hline Country sample & 30 & 124 & & & 28 & 125 & & \\
\hline
\end{tabular}


Table 6: Covid-19 Containment Success

\begin{tabular}{|c|c|c|c|c|c|}
\hline & (1) & $(2)$ & $(3)$ & $(4)$ & $(5)$ \\
\hline & & & Covid-19 suc & cess rankin & \\
\hline & Deaths & Success & Success & Success & Success \\
\hline Containment success rank & $\begin{array}{c}-6.07^{* * *} \\
(0.36)\end{array}$ & & & & \\
\hline Containment (average) & & $\begin{array}{c}-77.43^{* * *} \\
(25.01)\end{array}$ & & & \\
\hline Stringency (average) & & & $\begin{array}{c}-86.60^{* * *} \\
(21.28)\end{array}$ & $\begin{array}{c}-96.55^{* * *} \\
(20.51)\end{array}$ & $\begin{array}{c}-83.90^{* * *} \\
(20.67)\end{array}$ \\
\hline Health policies (average) & & & $\begin{array}{l}70.22^{*} \\
(36.95)\end{array}$ & & $\begin{array}{c}62.87^{* *} \\
(27.15)\end{array}$ \\
\hline Travel controls (average) & & & & $\begin{array}{c}27.92^{* * *} \\
(7.23)\end{array}$ & \\
\hline Early containment (at 100 cases) & & $\begin{array}{c}10.77 \\
(17.85)\end{array}$ & & & \\
\hline Stringency (at 100 cases) & & & $\begin{array}{c}1.78 \\
(16.52)\end{array}$ & $\begin{array}{c}-2.63 \\
(15.70)\end{array}$ & \\
\hline Health policies (at 100 cases) & & & $\begin{array}{c}0.24 \\
(28.46)\end{array}$ & $\begin{array}{c}27.80 \\
(19.76)\end{array}$ & \\
\hline Early containment (PHRT) & & & & & $\begin{array}{l}-0.11 \\
(0.11)\end{array}$ \\
\hline Log GDP per capita & $\begin{array}{l}-2.10 \\
(27.31)\end{array}$ & $\begin{array}{c}0.25 \\
(6.21)\end{array}$ & $\begin{array}{l}-7.37 \\
(6.37)\end{array}$ & $\begin{array}{l}-5.16 \\
(5.94)\end{array}$ & $\begin{array}{l}-8.04 \\
(6.43)\end{array}$ \\
\hline EMDEs & $\begin{array}{c}-330.84^{* * *} \\
(48.71)\end{array}$ & $\begin{array}{c}-21.21^{*} \\
(11.23)\end{array}$ & $\begin{array}{l}-16.38 \\
(10.99)\end{array}$ & $\begin{array}{c}-17.72^{*} \\
(10.58)\end{array}$ & $\begin{array}{l}-18.14 \\
(11.14)\end{array}$ \\
\hline LIDCs & $\begin{array}{c}-495.83^{* * *} \\
(87.84)\end{array}$ & $\begin{array}{c}-5.12 \\
(19.90)\end{array}$ & $\begin{array}{c}-6.62 \\
(19.40)\end{array}$ & $\begin{array}{c}-6.34 \\
(18.66)\end{array}$ & $\begin{array}{c}-9.76 \\
(19.46)\end{array}$ \\
\hline Constant & $\begin{array}{c}138.29 \\
(109.49)\end{array}$ & $\begin{array}{l}-24.04 \\
(27.11)\end{array}$ & $\begin{array}{l}-42.44 \\
(27.61)\end{array}$ & $\begin{array}{c}-77.82^{* * *} \\
(28.65)\end{array}$ & $\begin{array}{l}-42.87 \\
(27.73)\end{array}$ \\
\hline Observations & 153 & 150 & 150 & 150 & 143 \\
\hline R-squared & 0.75 & 0.15 & 0.21 & 0.26 & 0.21 \\
\hline
\end{tabular}


Table 7: Effect of Containment Measures for Covid Performance Index

\begin{tabular}{|c|c|c|c|c|c|}
\hline & $\begin{array}{c}(1) \\
\text { Score }\end{array}$ & $\begin{array}{c}(2) \\
\text { Score }\end{array}$ & $\begin{array}{c}(3) \\
\text { Score }\end{array}$ & $\begin{array}{c}(4) \\
\text { Score }\end{array}$ & $\begin{array}{c}(5) \\
\text { Score }\end{array}$ \\
\hline Containment (2020 average) & $\begin{array}{c}-62.750^{* * *} \\
(13.046)\end{array}$ & & & & \\
\hline Containment (at 100 cases) & $\begin{array}{c}31.924^{* * *} \\
(8.574)\end{array}$ & & & & $\begin{array}{c}28.356^{* * *} \\
(7.900)\end{array}$ \\
\hline Stringency (2020 average) & & $\begin{array}{c}-57.148^{* * *} \\
(10.500)\end{array}$ & & $\begin{array}{c}-64.327^{* * *} \\
(10.170)\end{array}$ & $\begin{array}{c}-64.588^{* * *} \\
(10.084)\end{array}$ \\
\hline Health policies (2020 average) & & $\begin{array}{c}44.950^{* * *} \\
(13.252)\end{array}$ & & $\begin{array}{c}30.789 \\
(18.691)\end{array}$ & $\begin{array}{c}37.669^{* * *} \\
(12.620)\end{array}$ \\
\hline Stringency (at 100 cases) & & & $\begin{array}{l}10.555 \\
(8.747)\end{array}$ & $\begin{array}{c}21.541^{* * *} \\
(7.650)\end{array}$ & \\
\hline Health policies (at 100 cases) & & & $\begin{array}{c}22.866^{* *} \\
(10.906)\end{array}$ & $\begin{array}{c}13.488 \\
(13.669)\end{array}$ & \\
\hline Log GDP per capita & $\begin{array}{c}6.980^{* *} \\
(3.112)\end{array}$ & $\begin{array}{l}-1.337 \\
(3.136)\end{array}$ & $\begin{array}{c}2.376 \\
(3.609)\end{array}$ & $\begin{array}{c}1.386 \\
(3.088)\end{array}$ & $\begin{array}{c}1.621 \\
(3.060)\end{array}$ \\
\hline EMDE dummy & $\begin{array}{c}-15.389^{* * *} \\
(4.766)\end{array}$ & $\begin{array}{c}-11.100^{* *} \\
(4.534)\end{array}$ & $\begin{array}{c}-19.295^{* * *} \\
(5.146)\end{array}$ & $\begin{array}{c}-13.751^{* * *} \\
(4.400)\end{array}$ & $\begin{array}{c}-14.333^{* * *} \\
(4.356)\end{array}$ \\
\hline LIDC dummy & $\begin{array}{c}8.052 \\
(9.591)\end{array}$ & $\begin{array}{c}5.711 \\
(9.312)\end{array}$ & $\begin{array}{c}0.207 \\
(10.717)\end{array}$ & $\begin{array}{c}1.898 \\
(8.954)\end{array}$ & $\begin{array}{c}1.583 \\
(8.827)\end{array}$ \\
\hline Constant & $\begin{array}{c}60.540^{* * *} \\
(13.933)\end{array}$ & $\begin{array}{c}63.177^{* * *} \\
(13.683)\end{array}$ & $\begin{array}{c}30.688^{* *} \\
(14.499)\end{array}$ & $\begin{array}{c}52.069^{* * *} \\
(13.930)\end{array}$ & $\begin{array}{c}52.573^{* * *} \\
(13.195)\end{array}$ \\
\hline Observations & 96 & 96 & 96 & 96 & 96 \\
\hline R-squared & 0.425 & 0.453 & 0.296 & 0.520 & 0.522 \\
\hline
\end{tabular}

Table 8: GDP Per Capita Growth Revisions for 2020 - Relation with Deaths

\begin{tabular}{|c|c|c|c|c|c|c|}
\hline \multirow[b]{4}{*}{ WEO Edition } & (1) & $(2)$ & $(3)$ & (4) & $(5)$ & (6) \\
\hline & \multicolumn{6}{|c|}{2020 GDP Growth Per Capita (\%) } \\
\hline & \multicolumn{4}{|c|}{ Difference vs. Jan 2020 WEO Forecast } & \multirow{2}{*}{$\begin{array}{l}\text { vs. } 2019 \\
\text { Jan } 2021 \\
\end{array}$} & \multirow{2}{*}{$\begin{array}{c}\text { Actual } \\
\text { Jan } 2021\end{array}$} \\
\hline & Apr 2020 & Jul 2020 & Oct 2020 & Jan 2021 & & \\
\hline Cumulated Covid-19 deaths & $\begin{array}{l}-2.73^{*} \\
(1.38)\end{array}$ & $\begin{array}{c}-5.34^{* * *} \\
(1.56)\end{array}$ & $\begin{array}{c}-3.78^{* * *} \\
(1.32)\end{array}$ & $\begin{array}{c}-2.14^{* *} \\
(0.88)\end{array}$ & $\begin{array}{c}-2.58 * * * \\
(0.88)\end{array}$ & $\begin{array}{c}-2.29^{* *} \\
(0.96)\end{array}$ \\
\hline Log GDP per capita & $\begin{array}{c}0.36 \\
(0.31)\end{array}$ & $\begin{array}{c}0.08 \\
(0.41)\end{array}$ & $\begin{array}{c}0.41 \\
(0.52)\end{array}$ & $\begin{array}{c}0.86 \\
(0.53)\end{array}$ & $\begin{array}{c}0.71 \\
(0.52)\end{array}$ & $\begin{array}{l}0.97^{*} \\
(0.57)\end{array}$ \\
\hline EMDE dummy & $\begin{array}{c}1.98^{* * *} \\
(0.55)\end{array}$ & $\begin{array}{c}0.31 \\
(0.73)\end{array}$ & $\begin{array}{l}-0.89 \\
(0.90)\end{array}$ & $\begin{array}{l}-1.55^{*} \\
(0.93)\end{array}$ & $\begin{array}{l}-0.87 \\
(0.92)\end{array}$ & $\begin{array}{l}-1.09 \\
(1.01)\end{array}$ \\
\hline LIDC dummy & $\begin{array}{c}4.27^{* * *} \\
(0.99)\end{array}$ & $\begin{array}{c}2.94^{* *} \\
(1.34)\end{array}$ & $\begin{array}{c}3.86^{* *} \\
(1.68)\end{array}$ & $\begin{array}{l}2.60 \\
(1.74)\end{array}$ & $\begin{array}{c}2.51 \\
(1.73)\end{array}$ & $\begin{array}{l}3.63^{*} \\
(1.89)\end{array}$ \\
\hline Constant & $\begin{array}{c}-9.58^{* * *} \\
(1.22)\end{array}$ & $\begin{array}{c}-9.34^{* * *} \\
(1.63)\end{array}$ & $\begin{array}{c}-8.19^{* * *} \\
(2.06)\end{array}$ & $\begin{array}{c}-9.22^{* * *} \\
(2.12)\end{array}$ & $\begin{array}{c}-8.49^{* * *} \\
(2.10)\end{array}$ & $\begin{array}{c}-8.13^{* * *} \\
(2.29)\end{array}$ \\
\hline Observations & 139 & 147 & 153 & 155 & 155 & 155 \\
\hline R-squared & 0.33 & 0.27 & 0.28 & 0.17 & 0.16 & 0.18 \\
\hline
\end{tabular}


Table 9: GDP Growth Revisions for 2020 - Relation with Deaths

\begin{tabular}{|c|c|c|c|c|c|c|}
\hline \multirow[b]{4}{*}{ WEO Edition } & (1) & $(2)$ & $(3)$ & (4) & $(5)$ & (6) \\
\hline & \multicolumn{6}{|c|}{2020 GDP Growth (\%) } \\
\hline & \multicolumn{4}{|c|}{ Difference vs. Jan 2020 WEO Forecast } & \multirow{2}{*}{$\begin{array}{l}\text { vs. } 2019 \\
\text { Jan } 2021 \\
\end{array}$} & \multirow{2}{*}{$\begin{array}{c}\text { Actual } \\
\text { Jan } 2021\end{array}$} \\
\hline & Apr 2020 & Jul 2020 & Oct 2020 & Jan 2021 & & \\
\hline \multirow[t]{2}{*}{ Cumulated Covid-19 deaths } & $-2.653^{*}$ & $-5.270 * * *$ & $-3.711^{* * *}$ & $-2.118^{* *}$ & $-2.538^{* * *}$ & $-2.872^{* * *}$ \\
\hline & $(1.376)$ & $(1.585)$ & $(1.278)$ & $(0.876)$ & $(0.867)$ & $(0.949)$ \\
\hline \multirow[t]{2}{*}{ Log GDP per capita } & 0.379 & 0.093 & 0.599 & 0.722 & 0.566 & 0.662 \\
\hline & $(0.308)$ & $(0.418)$ & $(0.501)$ & $(0.522)$ & $(0.516)$ & $(0.565)$ \\
\hline \multirow[t]{2}{*}{ EMDEs } & $1.963^{* * *}$ & 0.273 & -1.118 & $-1.827^{* *}$ & -1.041 & -1.232 \\
\hline & $(0.545)$ & $(0.745)$ & $(0.868)$ & $(0.924)$ & $(0.915)$ & $(1.002)$ \\
\hline \multirow[t]{2}{*}{ LIDCs } & $4.262^{* * *}$ & $2.879^{* *}$ & $2.718^{*}$ & 2.109 & 2.133 & $4.015^{* *}$ \\
\hline & $(0.985)$ & $(1.361)$ & (1.618) & $(1.729)$ & $(1.711)$ & $(1.874)$ \\
\hline \multirow[t]{2}{*}{ Constant } & $-9.710^{* * *}$ & $-9.456^{* * *}$ & $-9.540^{* * *}$ & $-8.788^{* * *}$ & $-8.128^{* * *}$ & $-6.094^{* * *}$ \\
\hline & $(1.215)$ & (1.653) & $(1.990)$ & $(2.102)$ & $(2.080)$ & $(2.278)$ \\
\hline Observations & 139 & 147 & 153 & 155 & 155 & 155 \\
\hline R-squared & 0.325 & 0.257 & 0.200 & 0.176 & 0.161 & 0.275 \\
\hline
\end{tabular}

Table 10: Primary Balance Revisions for 2020 - Relation with Deaths

\begin{tabular}{|c|c|c|c|c|c|c|}
\hline \multirow[b]{4}{*}{ WEO Edition } & (1) & $(2)$ & (3) & $(4)$ & $(5)$ & (6) \\
\hline & \multicolumn{6}{|c|}{2020 Primary Balance ( $\%$ of GDP) } \\
\hline & \multicolumn{4}{|c|}{ Difference vs. Jan 2020 WEO Forecast } & \multirow{2}{*}{$\begin{array}{l}\text { vs. } 2019 \\
\text { Jan } 2021\end{array}$} & \multirow{2}{*}{$\begin{array}{c}\text { Actual } \\
\text { Jan } 2021\end{array}$} \\
\hline & Apr 2020 & Jul 2020 & Oct 2020 & Jan 2021 & & \\
\hline Cumulated Covid-19 deaths & $\begin{array}{l}1.245 \\
(2.103)\end{array}$ & $\begin{array}{c}0.657 \\
(1.756)\end{array}$ & $\begin{array}{c}-1.217 \\
(1.142)\end{array}$ & $\begin{array}{c}-0.352 \\
(0.751)\end{array}$ & $\begin{array}{c}-0.555 \\
(0.831)\end{array}$ & $\begin{array}{c}-0.390 \\
(0.951)\end{array}$ \\
\hline Log GDP per capita & $\begin{array}{c}-1.204^{* *} \\
(0.468)\end{array}$ & $\begin{array}{c}-1.321^{* * *} \\
(0.459)\end{array}$ & $\begin{array}{l}-0.458 \\
(0.446)\end{array}$ & $\begin{array}{l}-0.552 \\
(0.441)\end{array}$ & $\begin{array}{c}-1.137^{* *} \\
(0.487)\end{array}$ & $\begin{array}{c}-1.368^{* *} \\
(0.558)\end{array}$ \\
\hline EMDEs & $\begin{array}{c}0.900 \\
(0.835)\end{array}$ & $\begin{array}{c}2.447^{* * *} \\
(0.824)\end{array}$ & $\begin{array}{c}2.148^{* * * *} \\
(0.773)\end{array}$ & $\begin{array}{l}1.476^{*} \\
(0.785)\end{array}$ & $\begin{array}{l}1.150 \\
(0.868)\end{array}$ & $\begin{array}{l}-0.481 \\
(0.994)\end{array}$ \\
\hline LIDCs & $\begin{array}{l}1.042 \\
(1.489)\end{array}$ & $\begin{array}{l}2.588^{*} \\
(1.487)\end{array}$ & $\begin{array}{c}4.299^{* * *} \\
(1.433)\end{array}$ & $\begin{array}{c}3.649^{* *} \\
(1.455)\end{array}$ & $\begin{array}{l}2.006 \\
(1.610)\end{array}$ & $\begin{array}{c}-0.268 \\
(1.843)\end{array}$ \\
\hline Constant & $\begin{array}{l}-1.946 \\
(1.836)\end{array}$ & $\begin{array}{c}-4.246^{* *} \\
(1.805)\end{array}$ & $\begin{array}{c}-6.343^{* * *} \\
(1.762)\end{array}$ & $\begin{array}{c}-5.366^{* * *} \\
(1.767)\end{array}$ & $\begin{array}{l}-3.231 \\
(1.955)\end{array}$ & $\begin{array}{l}-1.919 \\
(2.238)\end{array}$ \\
\hline Observations & 136 & 144 & 151 & 153 & 153 & 153 \\
\hline R-squared & 0.234 & 0.382 & 0.352 & 0.321 & 0.297 & 0.169 \\
\hline
\end{tabular}


Table 11: Covid-19 Fiscal Support Packages - Relation with Deaths

\begin{tabular}{|c|c|c|c|c|c|c|}
\hline \multirow[b]{4}{*}{ FM Edition } & \multirow[t]{2}{*}{ (1) } & $(2)$ & $(3)$ & (4) & \multirow{2}{*}{$\begin{array}{c}(5) \\
f(G D P)\end{array}$} & \multirow[t]{2}{*}{ (6) } \\
\hline & & id-19 Abov & e-the-line $\mathrm{F}$ & iscal Support (\% & & \\
\hline & \multirow{2}{*}{$\begin{array}{c}\text { Support in } 2020 \\
\text { Jan } 2021\end{array}$} & \multicolumn{2}{|c|}{ Total support } & \multirow{2}{*}{$\begin{array}{c}\text { Support in } 2020 \\
\text { Jan } 2021\end{array}$} & \multicolumn{2}{|c|}{ Total support } \\
\hline & & Jan 2021 & Oct 2020 & & Jan 2021 & Oct 2020 \\
\hline Covid-19 deaths & $\begin{array}{c}0.54 \\
(0.65)\end{array}$ & $\begin{array}{c}0.30 \\
(0.89)\end{array}$ & $\begin{array}{c}0.14 \\
(0.66)\end{array}$ & $\begin{array}{c}0.98 \\
(0.87)\end{array}$ & $\begin{array}{c}1.63 \\
(1.18)\end{array}$ & $\begin{array}{l}2.01^{* *} \\
(0.85)\end{array}$ \\
\hline Covid-19 deaths x AE dummy & & & & $\begin{array}{l}-1.03 \\
(1.32)\end{array}$ & $\begin{array}{l}-3.08^{*} \\
(1.79)\end{array}$ & $\begin{array}{c}-4.30^{* * *} \\
(1.29)\end{array}$ \\
\hline Log GDP per capita & $\begin{array}{c}0.07 \\
(0.38)\end{array}$ & $\begin{array}{l}-0.18 \\
(0.51)\end{array}$ & $\begin{array}{c}0.28 \\
(0.38)\end{array}$ & $\begin{array}{c}0.06 \\
(0.38)\end{array}$ & $\begin{array}{l}-0.23 \\
(0.51)\end{array}$ & $\begin{array}{c}0.21 \\
(0.37)\end{array}$ \\
\hline EMDEs & $\begin{array}{c}-2.72^{* * * *} \\
(0.67)\end{array}$ & $\begin{array}{c}-4.73^{* * *} \\
(0.91)\end{array}$ & $\begin{array}{c}-3.49 * * * \\
(0.68)\end{array}$ & $\begin{array}{c}-3.22^{* * *} \\
(0.93)\end{array}$ & $\begin{array}{c}-6.25^{* * *} \\
(1.26)\end{array}$ & $\begin{array}{c}-5.60 \text { *** } \\
(0.91)\end{array}$ \\
\hline LIDCs & $\begin{array}{c}-2.89^{* *} \\
(1.23)\end{array}$ & $\begin{array}{c}-5.20^{* * *} \\
(1.69)\end{array}$ & $\begin{array}{c}-3.62^{* * *} \\
(1.25)\end{array}$ & $\begin{array}{c}-3.28^{* *} \\
(1.34)\end{array}$ & $\begin{array}{c}-6.38^{* * *} \\
(1.81)\end{array}$ & $\begin{array}{c}-5.27^{* * *} \\
(1.31)\end{array}$ \\
\hline Constant & $\begin{array}{c}5.41 * * * \\
(1.51)\end{array}$ & $\begin{array}{c}8.35^{* * *} \\
(2.06)\end{array}$ & $\begin{array}{c}5.67^{* * *} \\
(1.53)\end{array}$ & $\begin{array}{c}5.80 * * * \\
(1.59)\end{array}$ & $\begin{array}{c}9.52^{* * *} \\
(2.16)\end{array}$ & $\begin{array}{c}7.31^{* * * *} \\
(1.56)\end{array}$ \\
\hline Observations & 147 & 147 & 146 & 147 & 147 & 146 \\
\hline R-squared & 0.22 & 0.25 & 0.32 & 0.22 & 0.27 & 0.37 \\
\hline
\end{tabular}


Figure 14: OLS: Effect of Lower Deaths on Medium-Term WEO Growth Projections

(a) Effect on WEO Projection Revisions vs Jan 2020 WEO
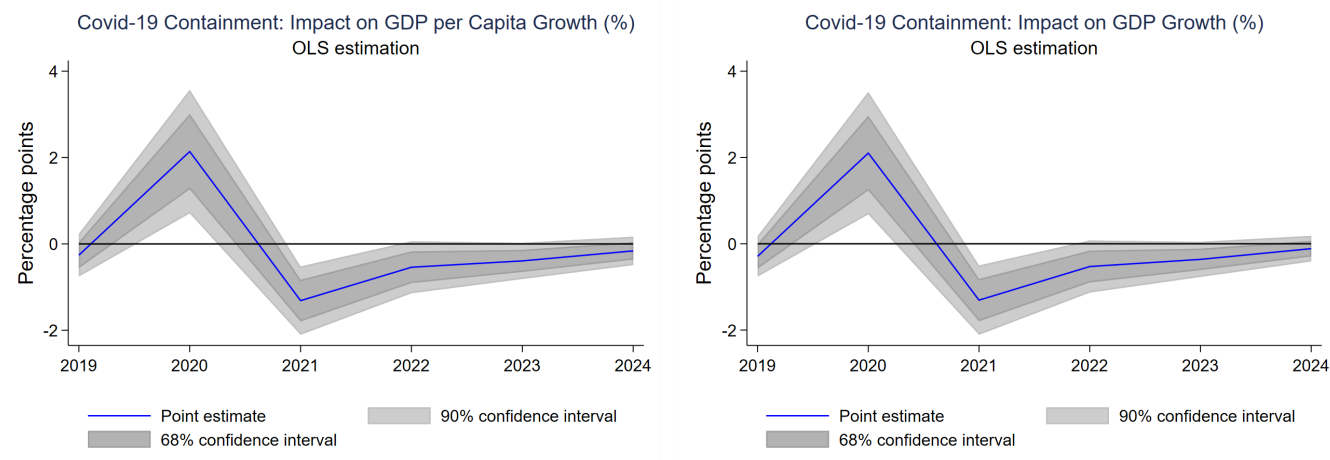

(b) Effect on WEO Projections, without controlling for 2019
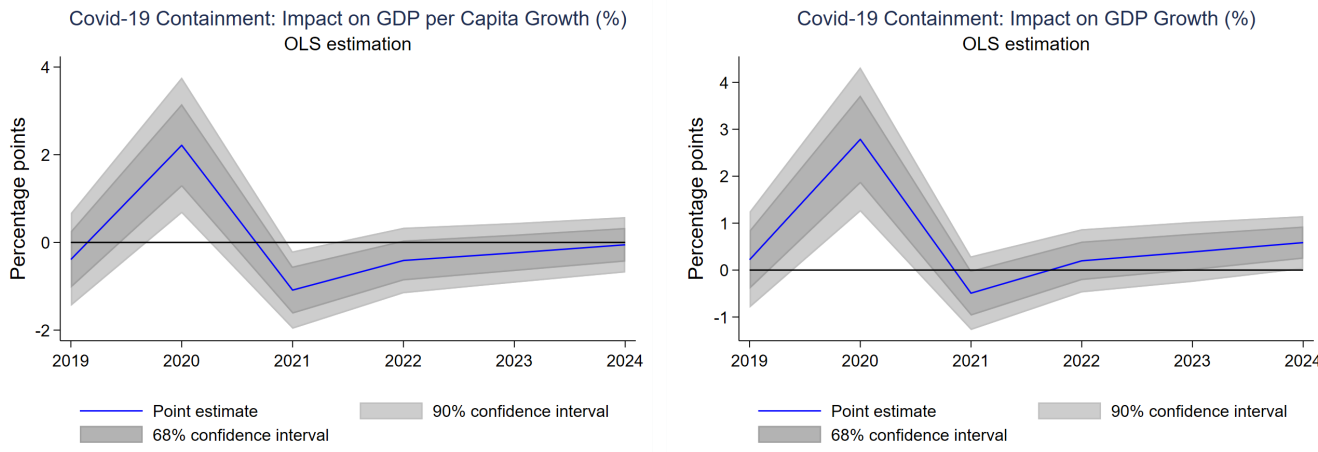

(c) Effect on WEO Projections, controlling for 2019
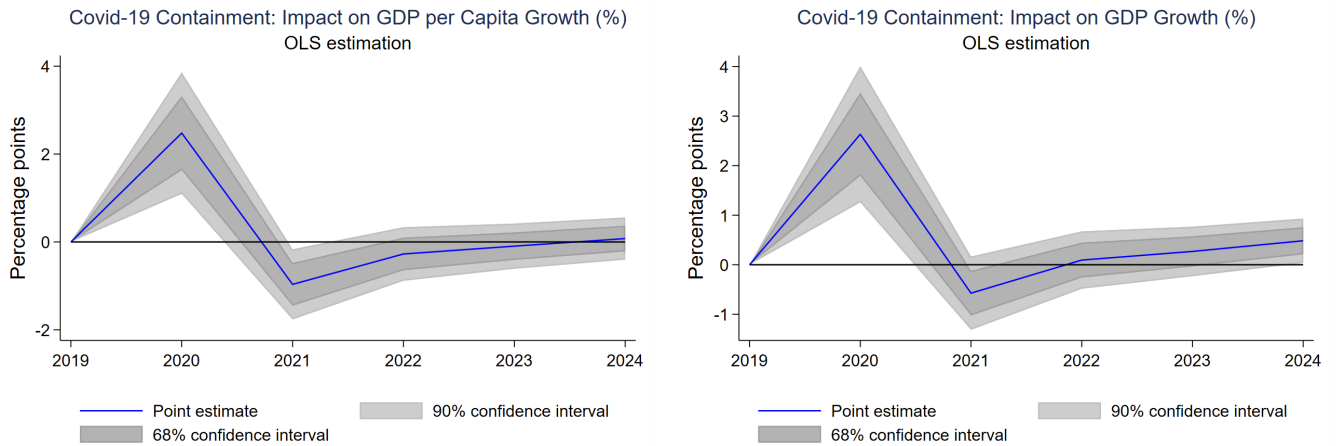

Note: This plots regression coefficients (and $68 \%$ and $90 \%$ confidence intervals) of an OLS regression of mediumterm WEO revisions on Covid-19 deaths per capita, controlling for log GDP per capita and WEO income group dummies. 
Figure 15: OLS: Effect of Lower Deaths on Medium-Term WEO Fiscal Projections

(a) Effect on WEO Projection Revisions vs Jan 2020 WEO
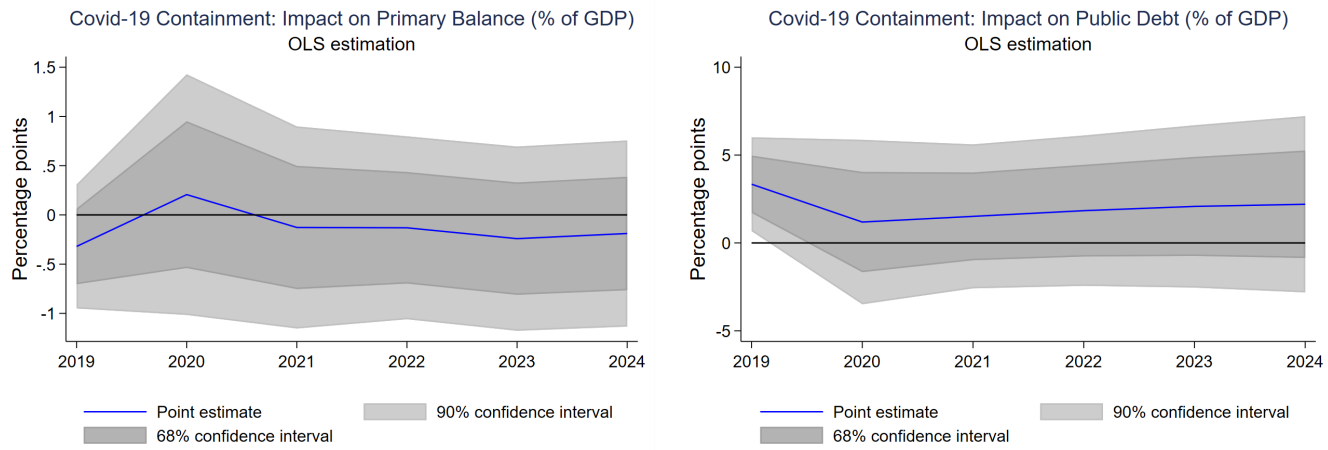

Effect on WEO Projections, without controlling for 2019
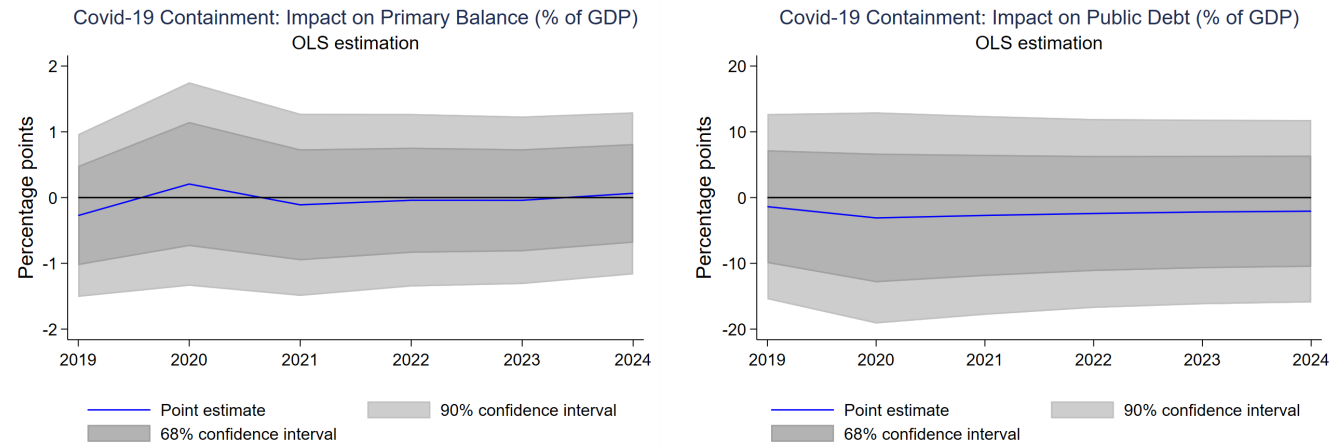

(c) Effect on WEO Projections, controlling for 2019
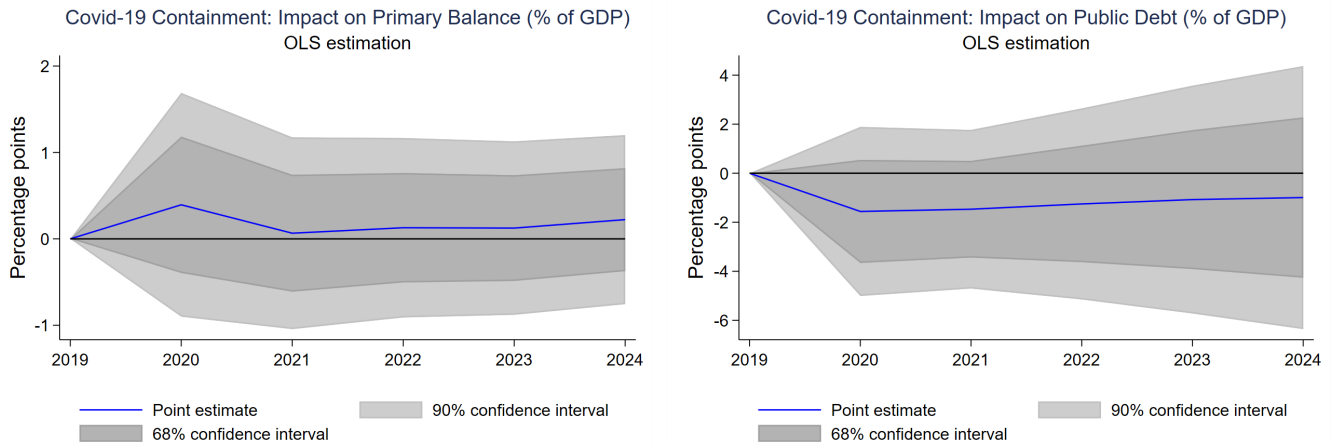

Note: This plots regression coefficients (and $68 \%$ and $90 \%$ confidence intervals) of an OLS regression of mediumterm WEO revisions on Covid-19 deaths per capita instrumented by past SARS experience, controlling for log GDP per capita and WEO income group dummies. 
Table 12: 2020 GDP Growth - Relation with Covid-19 Containment Success

\begin{tabular}{|c|c|c|c|c|c|c|}
\hline & \multirow{2}{*}{\multicolumn{3}{|c|}{$\begin{array}{c}(1) \\
2020 \text { GDP Per Capita Growth }(\%)\end{array}$}} & \multirow{2}{*}{\multicolumn{3}{|c|}{$\begin{array}{l}(5) \quad(6) \\
2020 \text { GDP Growth }(\%)\end{array}$}} \\
\hline & & & & & & \\
\hline & $\begin{array}{l}\text { Actual } \\
2020\end{array}$ & $\begin{array}{c}\text { Change } \\
\text { vs. } 2019\end{array}$ & $\begin{array}{c}\text { Revision } \\
\text { vs. Jan } 2020\end{array}$ & $\begin{array}{c}\text { Actual } \\
2020\end{array}$ & $\begin{array}{l}\text { Change } \\
\text { vs. } 2019\end{array}$ & $\begin{array}{c}\text { Revision } \\
\text { vs. Jan } 2020\end{array}$ \\
\hline Containment success rank & $\begin{array}{c}0.019^{* * *} \\
(0.007)\end{array}$ & $\begin{array}{c}0.015^{* *} \\
(0.007)\end{array}$ & $\begin{array}{l}0.013^{*} \\
(0.007)\end{array}$ & $\begin{array}{c}0.017^{* *} \\
(0.007)\end{array}$ & $\begin{array}{c}0.015^{* *} \\
(0.007)\end{array}$ & $\begin{array}{c}0.014^{* *} \\
(0.007)\end{array}$ \\
\hline Log GDP per capita & $\begin{array}{l}1.006^{*} \\
(0.563)\end{array}$ & $\begin{array}{c}0.720 \\
(0.528)\end{array}$ & $\begin{array}{c}0.877 \\
(0.530)\end{array}$ & $\begin{array}{c}0.679 \\
(0.570)\end{array}$ & $\begin{array}{c}0.578 \\
(0.523)\end{array}$ & $\begin{array}{c}0.739 \\
(0.524)\end{array}$ \\
\hline EMDEs & $\begin{array}{c}-0.344 \\
(1.005)\end{array}$ & $\begin{array}{l}-0.104 \\
(0.942)\end{array}$ & $\begin{array}{l}-0.928 \\
(0.945)\end{array}$ & $\begin{array}{c}-0.406 \\
(1.016)\end{array}$ & $\begin{array}{l}-0.289 \\
(0.933)\end{array}$ & $\begin{array}{l}-1.194 \\
(0.935)\end{array}$ \\
\hline LIDCs & $\begin{array}{c}4.746^{* * *} \\
(1.812)\end{array}$ & $\begin{array}{l}3.756^{* *} \\
(1.699)\end{array}$ & $\begin{array}{l}3.631^{* *} \\
(1.704)\end{array}$ & $\begin{array}{c}5.399^{* * *} \\
(1.833)\end{array}$ & $\begin{array}{l}3.360^{* *} \\
(1.682)\end{array}$ & $\begin{array}{l}3.133^{*} \\
(1.687)\end{array}$ \\
\hline Constant & $\begin{array}{c}-8.086^{* * *} \\
(2.259)\end{array}$ & $\begin{array}{c}-8.843^{* * *} \\
(2.118)\end{array}$ & $\begin{array}{c}-9.476^{* * *} \\
(2.124)\end{array}$ & $\begin{array}{c}-6.457^{* * *} \\
(2.285)\end{array}$ & $\begin{array}{c}-8.483^{* * *} \\
(2.096)\end{array}$ & $\begin{array}{c}-8.993^{* * *} \\
(2.103)\end{array}$ \\
\hline Observations & 153 & 153 & 153 & 153 & 153 & 153 \\
\hline R-squared & 0.195 & 0.143 & 0.168 & 0.263 & 0.144 & 0.173 \\
\hline
\end{tabular}

Table 13: 2020 Fiscal Policy - Relation with Covid-19 Containment Success

\begin{tabular}{|c|c|c|c|c|c|c|}
\hline & \multirow{2}{*}{\multicolumn{3}{|c|}{$\begin{array}{c}(1) \quad(3) \\
2020 \text { Primary Balance }(\% \text { of GDP) }\end{array}$}} & \multirow{2}{*}{\multicolumn{3}{|c|}{ 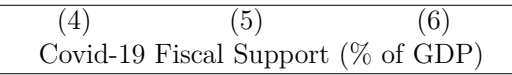 }} \\
\hline & & & & & & \\
\hline & \multirow{2}{*}{$\begin{array}{c}\text { Actual } \\
2020\end{array}$} & \multirow{2}{*}{$\begin{array}{l}\text { Change } \\
\text { vs. } 2019\end{array}$} & \multirow{2}{*}{$\begin{array}{c}\text { Revision } \\
\text { vs. Jan } 2020\end{array}$} & \multicolumn{3}{|c|}{ Announced fiscal packages } \\
\hline & & & & Impl. 2020 & FM Jan 2021 & FM Oct 2020 \\
\hline \multirow[t]{2}{*}{ Containment success rank } & 0.012 & 0.009 & 0.006 & 0.001 & 0.004 & 0.002 \\
\hline & $(0.007)$ & $(0.006)$ & $(0.006)$ & $(0.005)$ & $(0.007)$ & $(0.005)$ \\
\hline \multirow[t]{2}{*}{ Log GDP per capita } & $-1.356^{* *}$ & $-1.155^{* *}$ & -0.576 & 0.087 & -0.159 & 0.286 \\
\hline & $(0.555)$ & $(0.481)$ & $(0.432)$ & $(0.377)$ & $(0.513)$ & $(0.381)$ \\
\hline \multirow[t]{2}{*}{ EMDEs } & -0.016 & $1.689^{*}$ & $1.925^{* *}$ & $-2.834^{* * *}$ & $-4.717^{* * *}$ & $-3.502^{* * *}$ \\
\hline & $(0.988)$ & $(0.855)$ & $(0.769)$ & $(0.669)$ & $(0.913)$ & $(0.677)$ \\
\hline \multirow{2}{*}{ LIDCs } & 0.049 & 2.427 & $3.972^{* * *}$ & $-3.131 * *$ & $-5.318 * * *$ & $-3.673^{* * *}$ \\
\hline & $(1.778)$ & $(1.539)$ & $(1.384)$ & $(1.200)$ & $(1.636)$ & $(1.213)$ \\
\hline \multirow[t]{2}{*}{ Constant } & -1.495 & -3.086 & $-5.257^{* * *}$ & $5.709 * * *$ & $8.756^{* * *}$ & $5.874^{* * *}$ \\
\hline & $(2.217)$ & (1.919) & $(1.726)$ & $(1.510)$ & $(2.059)$ & $(1.527)$ \\
\hline Observations & 151 & 151 & 151 & 146 & 146 & 145 \\
\hline R-squared & 0.188 & 0.320 & 0.347 & 0.219 & 0.256 & 0.325 \\
\hline
\end{tabular}


Figure 16: OLS: Effect of Success Ranking on Medium-Term WEO Growth Projections

(a) Effect on WEO Projection Revisions vs Jan 2020 WEO
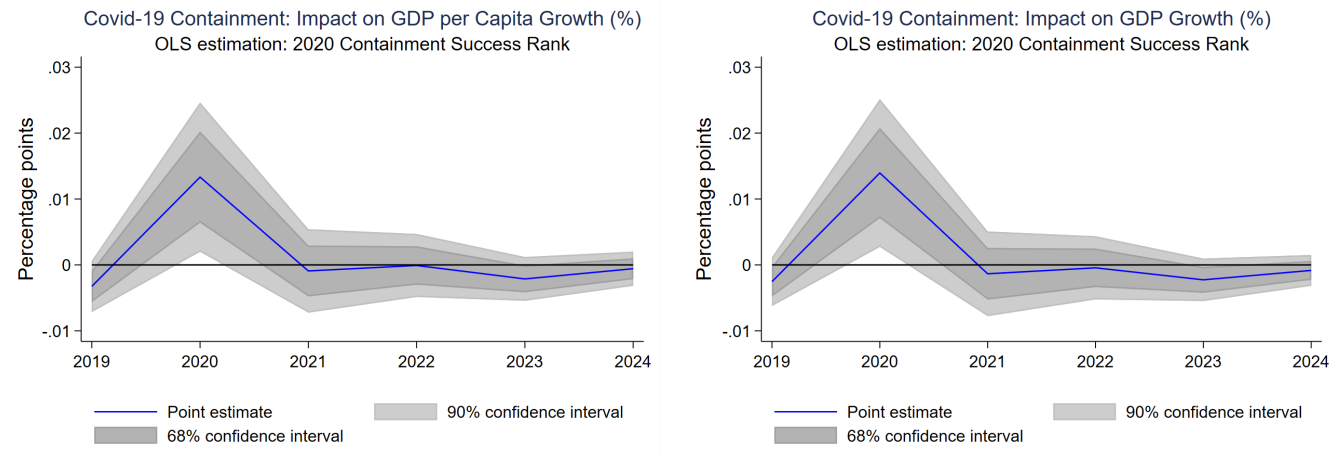

(b) Effect on WEO Projections, without controlling for 2019
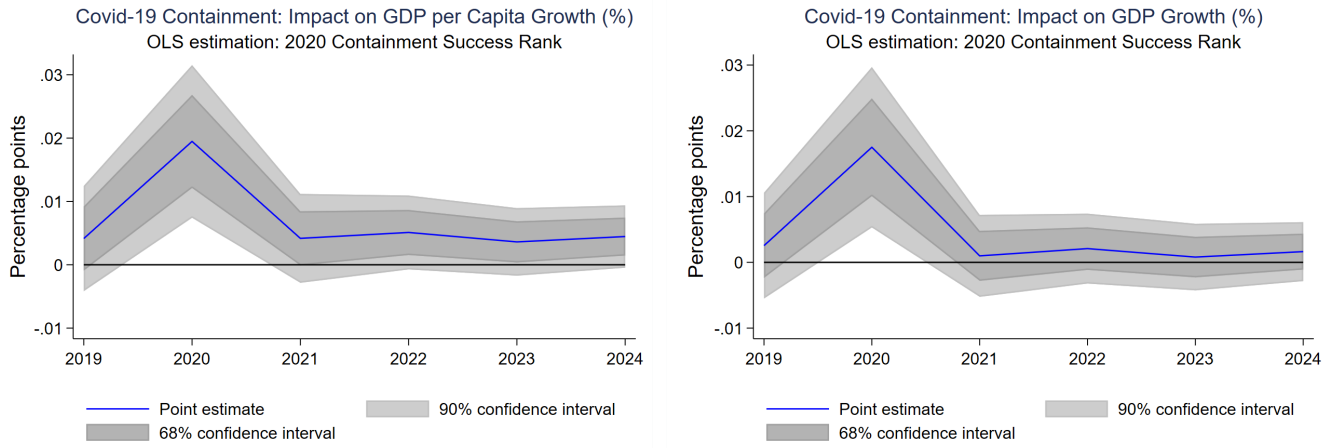

(c) Effect on WEO Projections, controlling for 2019
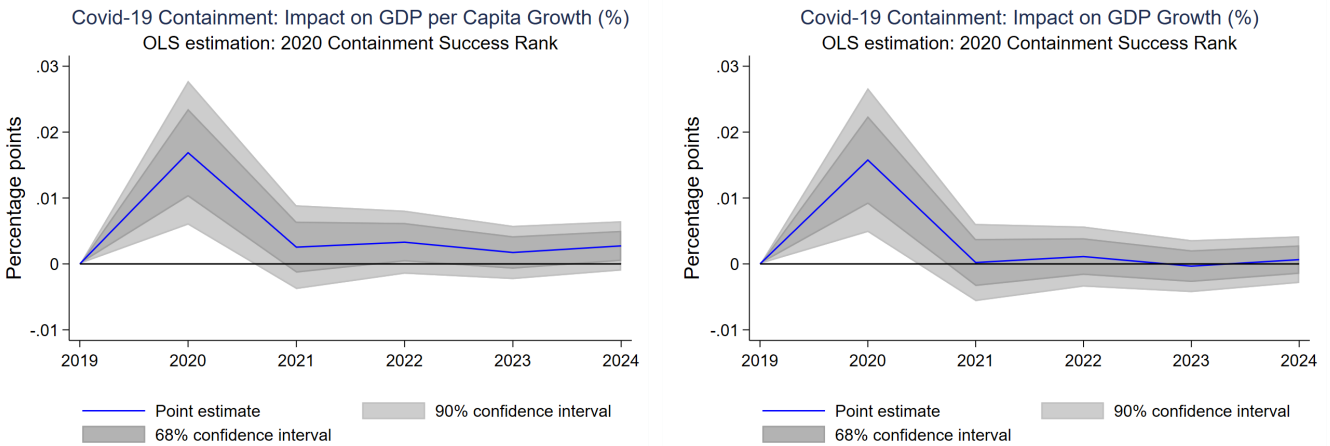

Note: This plots regression coefficients (and $68 \%$ and $90 \%$ confidence intervals) of an OLS regression of mediumterm WEO revisions on countries' Covid-19 success ranking (of age-adjusted Covid-19 deaths per capita), controlling for log GDP per capita and WEO income group dummies. 
Figure 17: OLS: Effect of Success Ranking on Medium-Term WEO Fiscal Projections

(a) Effect on WEO Projection Revisions vs Jan 2020 WEO
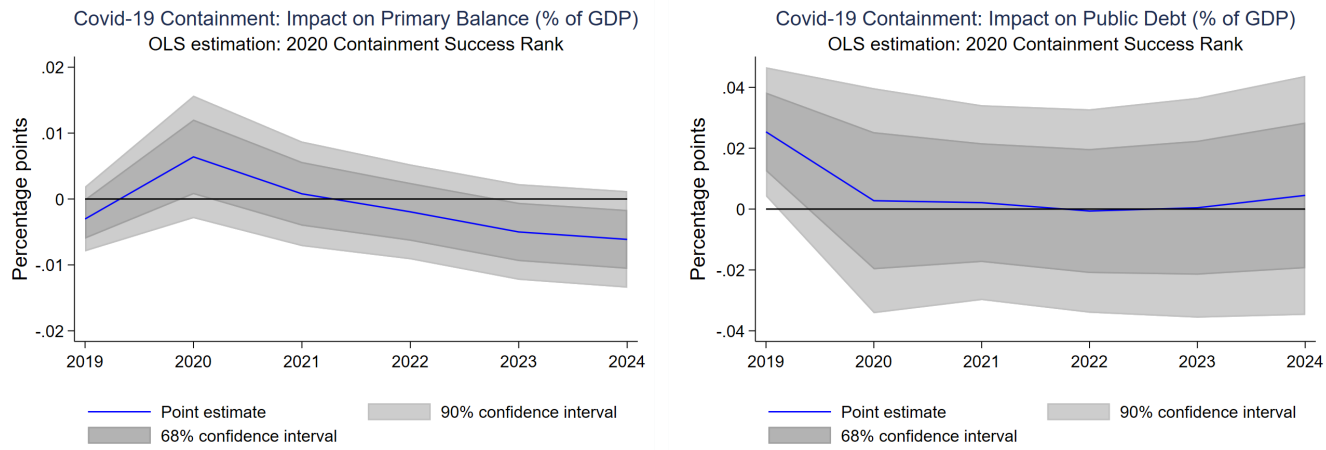

Effect on WEO Projections, without controlling for 2019
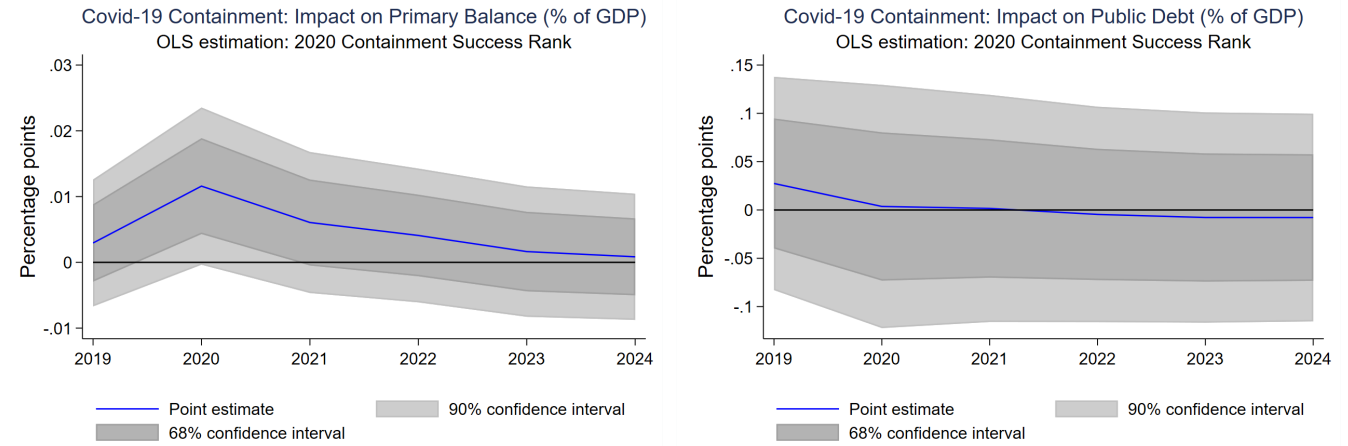

(c) Effect on WEO Projections, controlling for 2019
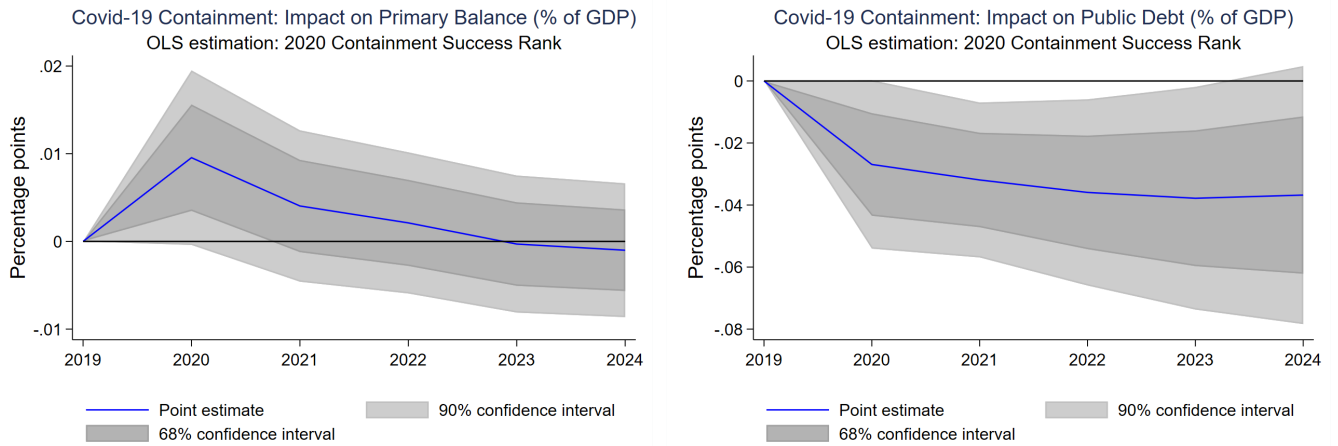

Note: This plots regression coefficients (and $68 \%$ and $90 \%$ confidence intervals) of an OLS regression of mediumterm WEO revisions on countries' Covid-19 success ranking (of age-adjusted Covid-19 deaths per capita), controlling for log GDP per capita and WEO income group dummies. 
Table 14: 2SLS Regression: Impact of Covid-19 Containment on GDP Growth

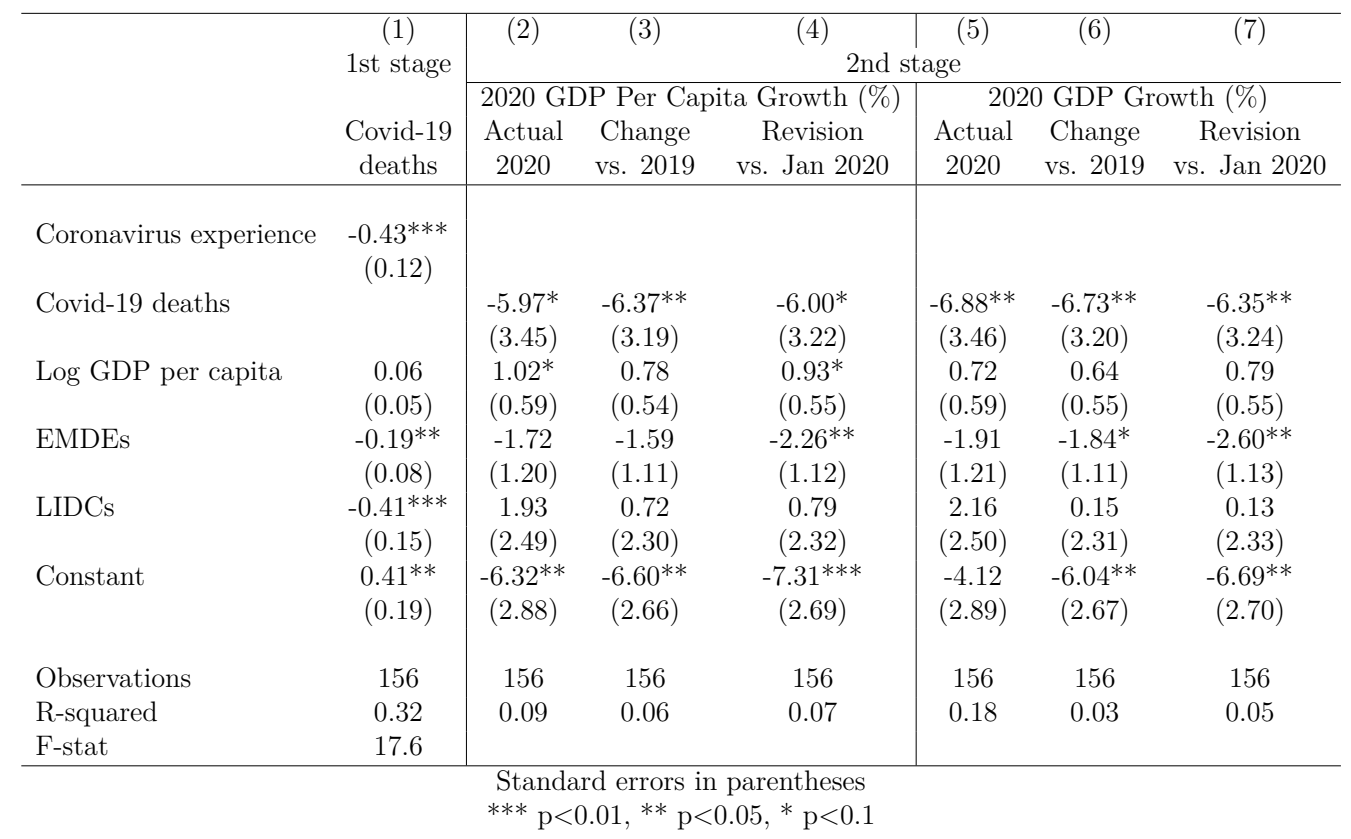

Table 15: 2SLS Regression: Impact of Covid-19 Containment on Fiscal Position

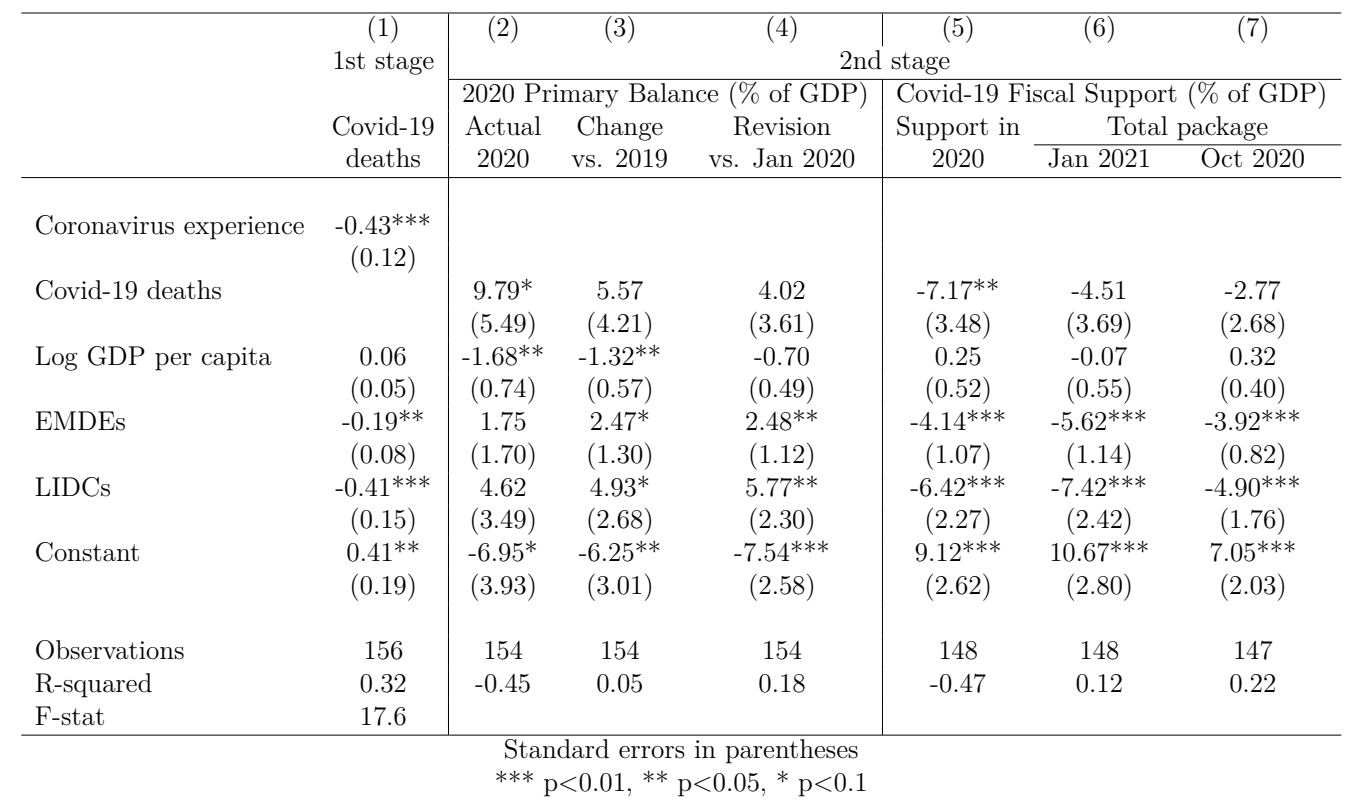


Table 16: 2SLS Regression: Robustness Tests

\begin{tabular}{|c|c|c|c|c|c|c|}
\hline & \multirow{3}{*}{$\begin{array}{c}(1) \\
\text { 1st stage } \\
\text { Deaths }\end{array}$} & $(2)$ & (3) & \multirow{3}{*}{$\begin{array}{c}(4) \\
\text { 1st stage } \\
\text { Deaths }\end{array}$} & \multirow{2}{*}{\multicolumn{2}{|c|}{ (5) (6) }} \\
\hline & & \multicolumn{2}{|c|}{ 2nd stage } & & & \\
\hline & & GDP growth & Prim. bal. & & GDP growth & Prim. bal \\
\hline Coronavirus experience & $\begin{array}{c}-0.43^{* * *} \\
(0.11)\end{array}$ & & & $\begin{array}{c}-0.42^{* * *} \\
(0.12)\end{array}$ & & \\
\hline Covid-19 deaths & & $\begin{array}{c}-6.81^{* *} \\
(3.47)\end{array}$ & $\begin{array}{l}9.37^{*} \\
(5.10)\end{array}$ & & $\begin{array}{l}-6.04^{*} \\
(3.48)\end{array}$ & $\begin{array}{c}7.69 \\
(4.70)\end{array}$ \\
\hline Median age & $\begin{array}{c}0.02^{* * * *} \\
(0.01)\end{array}$ & $\begin{array}{c}0.08 \\
(0.11)\end{array}$ & $\begin{array}{l}-0.17 \\
(0.14)\end{array}$ & & & \\
\hline Fiscal support in 2020 & & & & $\begin{array}{c}0.01 \\
(0.01)\end{array}$ & $\begin{array}{l}-0.07 \\
(0.12)\end{array}$ & $\begin{array}{c}-0.53^{* * *} \\
(0.16)\end{array}$ \\
\hline Log GDP per capita & $\begin{array}{l}-0.04 \\
(0.05)\end{array}$ & $\begin{array}{c}0.38 \\
(0.70)\end{array}$ & $\begin{array}{l}-0.96 \\
(0.84)\end{array}$ & $\begin{array}{c}0.06 \\
(0.05)\end{array}$ & $\begin{array}{c}0.60 \\
(0.56)\end{array}$ & $\begin{array}{c}-1.59^{* *} \\
(0.67)\end{array}$ \\
\hline EMDEs & $\begin{array}{l}-0.01 \\
(0.08)\end{array}$ & $\begin{array}{l}-1.31 \\
(1.12)\end{array}$ & $\begin{array}{c}0.39 \\
(1.35)\end{array}$ & $\begin{array}{l}-0.12 \\
(0.09)\end{array}$ & $\begin{array}{l}-1.65 \\
(1.15)\end{array}$ & $\begin{array}{c}-0.22 \\
(1.38)\end{array}$ \\
\hline LIDCs & $\begin{array}{l}-0.16 \\
(0.15)\end{array}$ & $\begin{array}{c}3.07 \\
(2.16)\end{array}$ & $\begin{array}{c}2.58 \\
(2.68)\end{array}$ & $\begin{array}{c}-0.33^{* *} \\
(0.16)\end{array}$ & $\begin{array}{c}2.24 \\
(2.35)\end{array}$ & $\begin{array}{c}2.01 \\
(2.84)\end{array}$ \\
\hline Constant & $\begin{array}{l}-0.25 \\
(0.22)\end{array}$ & $\begin{array}{c}-6.46^{* *} \\
(3.04)\end{array}$ & $\begin{array}{l}-1.94 \\
(3.64)\end{array}$ & $\begin{array}{c}0.29 \\
(0.20)\end{array}$ & $\begin{array}{l}-3.91 \\
(2.76)\end{array}$ & $\begin{array}{l}-2.81 \\
(3.27)\end{array}$ \\
\hline Observations & 155 & 155 & 153 & 148 & 148 & 147 \\
\hline R-squared & 0.40 & 0.18 & -0.34 & 0.32 & 0.21 & -0.12 \\
\hline F-stat & 19.6 & & & 13.2 & & \\
\hline
\end{tabular}

Table 17: 2SLS Regression: Instrument Robustness

\begin{tabular}{|c|c|c|c|c|c|c|c|c|}
\hline & $\begin{array}{c}(1) \\
\text { 1st stage }\end{array}$ & (2) & $\begin{array}{c}(3) \\
\text { 2nd stage }\end{array}$ & (4) & $\begin{array}{c}(5) \\
\text { 1st stage }\end{array}$ & (6) & $\begin{array}{c}(7) \\
\text { 2nd stage }\end{array}$ & (8) \\
\hline & $\begin{array}{c}\text { Covid-19 } \\
\text { deaths }\end{array}$ & $\begin{array}{c}\text { GDP } \\
\text { growth }\end{array}$ & $\begin{array}{l}\text { Primary } \\
\text { balance }\end{array}$ & $\begin{array}{c}\text { Fiscal } \\
\text { support }\end{array}$ & $\begin{array}{c}\text { Covid-19 } \\
\text { deaths }\end{array}$ & $\begin{array}{l}\text { GDP } \\
\text { growth }\end{array}$ & $\begin{array}{c}\text { Primary } \\
\text { balance }\end{array}$ & $\begin{array}{c}\text { Fiscal } \\
\text { support }\end{array}$ \\
\hline Epidemic experience & $\begin{array}{c}-0.29 * * * \\
(0.10)\end{array}$ & & & & & & & \\
\hline SARS experience & & & & & $\begin{array}{c}-0.41^{* * *} \\
(0.14)\end{array}$ & & & \\
\hline Covid-19 deaths & & $\begin{array}{l}-7.04^{*} \\
(4.15)\end{array}$ & $\begin{array}{c}9.60 \\
(6.72)\end{array}$ & $\begin{array}{l}-5.34 \\
(3.74)\end{array}$ & & $\begin{array}{c}-7.44^{*} \\
(4.33)\end{array}$ & $\begin{array}{c}18.08 \\
(11.72)\end{array}$ & $\begin{array}{c}-14.24^{* *} \\
(7.07)\end{array}$ \\
\hline Log GDP per capita & $\begin{array}{c}0.03 \\
(0.05)\end{array}$ & $\begin{array}{c}0.72 \\
(0.60)\end{array}$ & $\begin{array}{c}-1.68^{* *} \\
(0.75)\end{array}$ & $\begin{array}{c}0.22 \\
(0.47)\end{array}$ & $\begin{array}{c}0.04 \\
(0.05)\end{array}$ & $\begin{array}{c}0.73 \\
(0.60)\end{array}$ & $\begin{array}{c}-1.91^{*} \\
(1.08)\end{array}$ & $\begin{array}{c}0.38 \\
(0.80)\end{array}$ \\
\hline EMDEs & $\begin{array}{c}-0.20^{* *} \\
(0.08)\end{array}$ & $\begin{array}{l}-1.94 \\
(1.28)\end{array}$ & $\begin{array}{c}1.71 \\
(1.87)\end{array}$ & $\begin{array}{c}-3.83^{* * *} \\
(1.02)\end{array}$ & $\begin{array}{c}-0.21^{* *} \\
(0.08)\end{array}$ & $\begin{array}{l}-2.02 \\
(1.31)\end{array}$ & $\begin{array}{c}3.47 \\
(3.02)\end{array}$ & $\begin{array}{c}-5.32^{* * * *} \\
(1.81)\end{array}$ \\
\hline LIDCs & $\begin{array}{c}-0.45^{* * *} \\
(0.15)\end{array}$ & $\begin{array}{c}2.09 \\
(2.72)\end{array}$ & $\begin{array}{c}4.53 \\
(3.93)\end{array}$ & $\begin{array}{c}-5.60^{* *} \\
(2.23)\end{array}$ & $\begin{array}{c}-0.45^{* * *} \\
(0.15)\end{array}$ & $\begin{array}{c}1.90 \\
(2.80)\end{array}$ & $\begin{array}{c}8.54 \\
(6.46)\end{array}$ & $\begin{array}{c}-9.60^{* *} \\
(4.05)\end{array}$ \\
\hline Constant & $\begin{array}{c}0.50^{* * *} \\
(0.19)\end{array}$ & $\begin{array}{l}-4.04 \\
(3.11)\end{array}$ & $\begin{array}{l}-6.86 \\
(4.35)\end{array}$ & $\begin{array}{c}8.25^{* * *} \\
(2.54)\end{array}$ & $\begin{array}{c}0.47^{* *} \\
(0.19)\end{array}$ & $\begin{array}{l}-3.84 \\
(3.19)\end{array}$ & $\begin{array}{r}-11.02 \\
(7.04)\end{array}$ & $\begin{array}{c}12.48^{* * *} \\
(4.58)\end{array}$ \\
\hline Observations & 156 & 156 & 154 & 148 & 156 & 156 & 154 & 148 \\
\hline R-squared & 0.30 & 0.17 & -0.42 & -0.17 & 0.30 & 0.15 & -1.90 & -2.41 \\
\hline F-stat & 16.2 & & & & 16.0 & & & \\
\hline
\end{tabular}


Figure 18: 2SLS: Effect of Lower Deaths on Medium-Term WEO Growth Projections

(a) Effect on WEO Projection Revisions vs Jan 2020 WEO
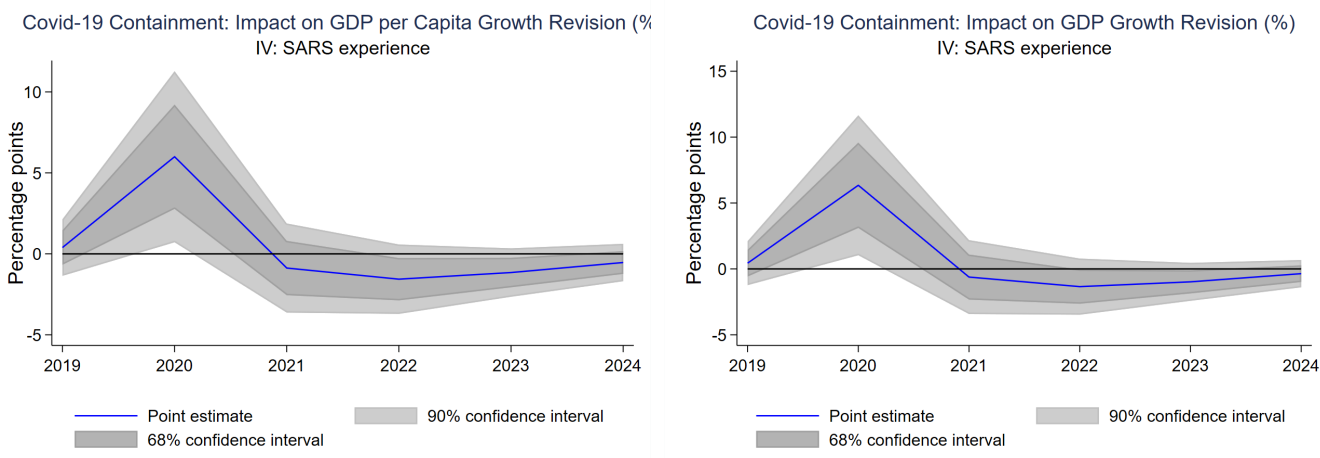

(b) Effect on WEO Projections, without controlling for 2019
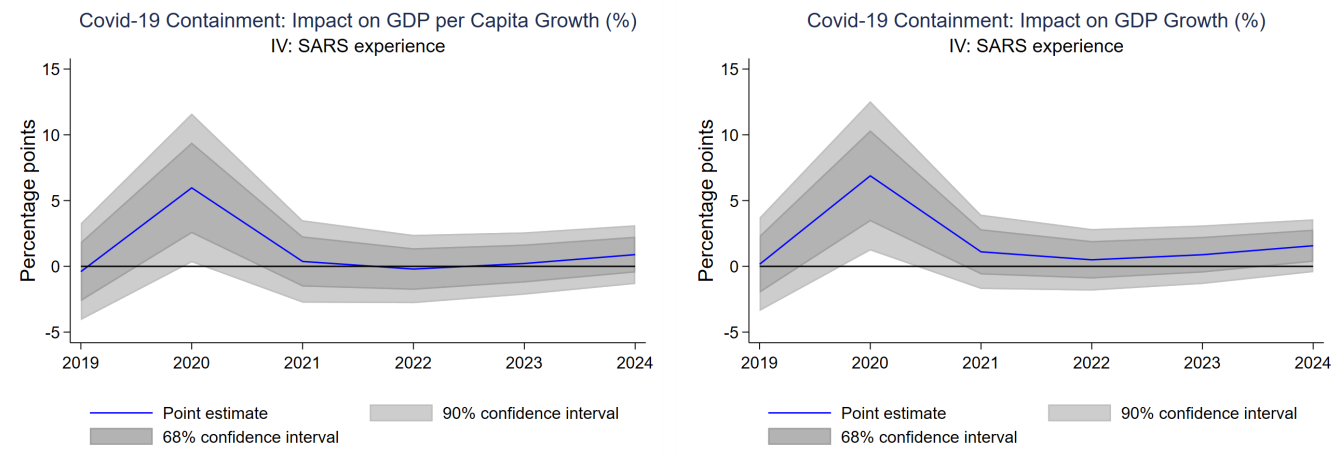

(c) Effect on WEO Projections, controlling for 2019
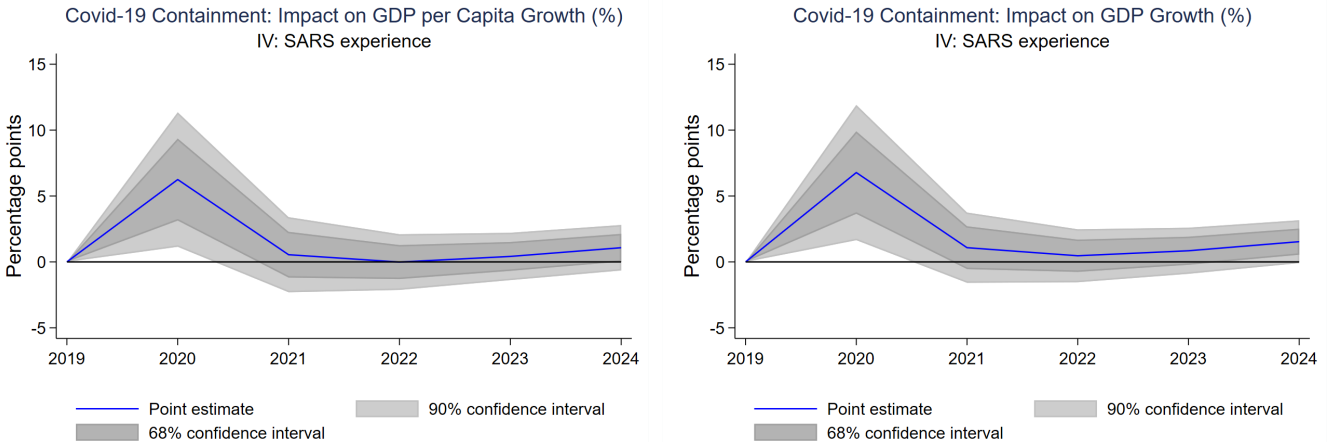

Note: This plots regression coefficients (and $68 \%$ and $90 \%$ confidence intervals) of a 2SLS regression of medium-term WEO revisions on Covid-19 deaths per capita instrumented by past SARS experience, controlling for log GDP per capita and WEO income group dummies. 
Figure 19: 2SLS: Effect of Lower Deaths on Medium-Term WEO Fiscal Projections

(a) Effect on WEO Projection Revisions vs Jan 2020 WEO
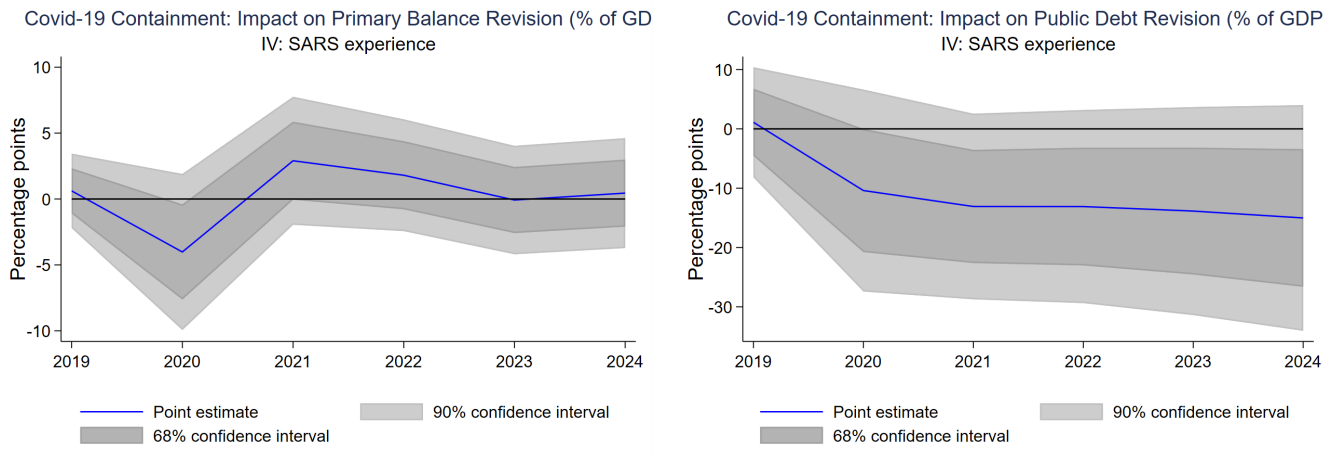

Effect on WEO Projections, without controlling for 2019
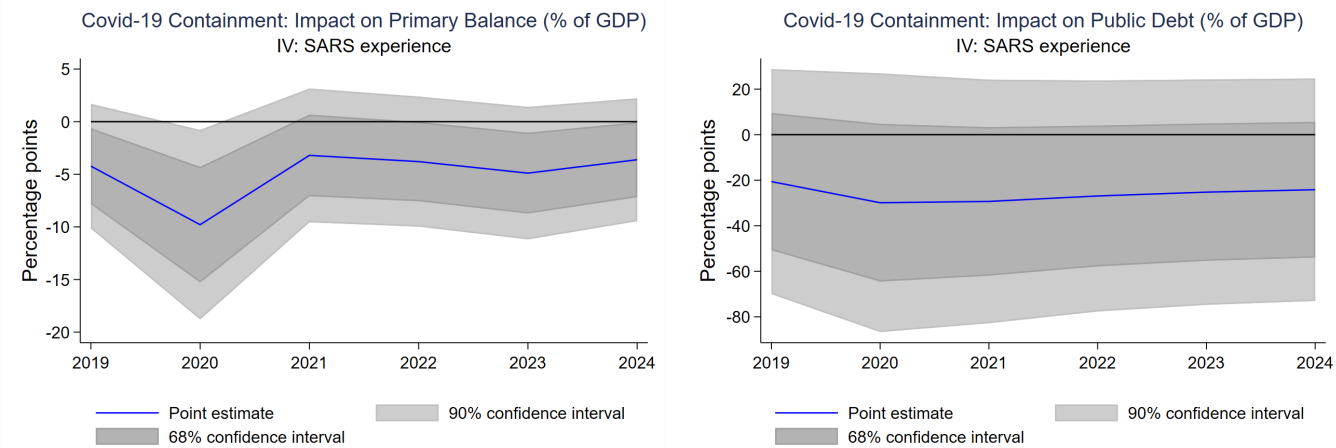

(c) Effect on WEO Projections, controlling for 2019
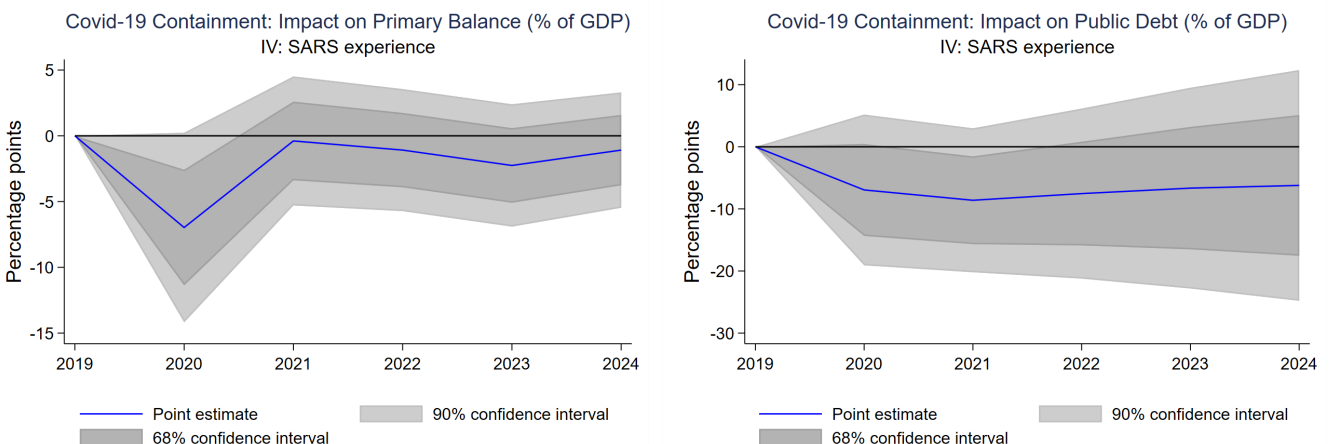

Note: This plots regression coefficients (and $68 \%$ and $90 \%$ confidence intervals) of a 2SLS regression of medium-term WEO revisions on Covid-19 deaths per capita instrumented by past SARS experience, controlling for log GDP per capita and WEO income group dummies. 
Table 18: GDP Per Capita Growth Revisions for 2020 - Relation with Stringency

\begin{tabular}{|c|c|c|c|c|c|c|}
\hline & (1) & $(2)$ & (3) & (4) & $(5)$ & (6) \\
\hline & \multicolumn{6}{|c|}{2020 GDP Growth Per Capita (\%) } \\
\hline & $\begin{array}{l}\text { Actual } \\
2020\end{array}$ & $\begin{array}{c}\text { Change } \\
\text { vs. } 2019\end{array}$ & $\begin{array}{c}\text { Revision } \\
\text { vs. Jan } 2020\end{array}$ & $\begin{array}{l}\text { Actual } \\
2020\end{array}$ & $\begin{array}{c}\text { Change } \\
\text { vs. } 2019 \\
\end{array}$ & $\begin{array}{c}\text { Revision } \\
\text { vs. Jan } 2020\end{array}$ \\
\hline Containment (average) & $\begin{array}{l}-2.32 \\
(2.15)\end{array}$ & $\begin{array}{l}-3.80^{*} \\
(2.05)\end{array}$ & $\begin{array}{c}-4.31^{* *} \\
(2.06)\end{array}$ & & & \\
\hline Stringency (average) & & & & $\begin{array}{l}-3.81^{*} \\
(2.03)\end{array}$ & $\begin{array}{l}-2.50 \\
(1.96)\end{array}$ & $\begin{array}{c}-3.94^{* *} \\
(1.96)\end{array}$ \\
\hline Health policies (average) & & & & $\begin{array}{c}3.86 \\
(2.63)\end{array}$ & $\begin{array}{l}-2.11 \\
(2.54)\end{array}$ & $\begin{array}{l}0.06 \\
(2.54)\end{array}$ \\
\hline Log GDP per capita & $\begin{array}{l}1.23^{* *} \\
(0.60)\end{array}$ & $\begin{array}{l}1.00^{*} \\
(0.58)\end{array}$ & $\begin{array}{l}1.13^{*} \\
(0.58)\end{array}$ & $\begin{array}{c}0.86 \\
(0.63)\end{array}$ & $\begin{array}{l}1.06^{*} \\
(0.61)\end{array}$ & $\begin{array}{l}1.00 \\
(0.61)\end{array}$ \\
\hline EMDEs & $\begin{array}{l}-0.11 \\
(1.12)\end{array}$ & $\begin{array}{c}0.04 \\
(1.07)\end{array}$ & $\begin{array}{l}-0.64 \\
(1.07)\end{array}$ & $\begin{array}{c}0.11 \\
(1.12)\end{array}$ & $\begin{array}{l}-0.07 \\
(1.08)\end{array}$ & $\begin{array}{l}-0.62 \\
(1.08)\end{array}$ \\
\hline LIDCs & $\begin{array}{c}5.94^{* * *} \\
(1.92)\end{array}$ & $\begin{array}{c}4.80^{* * *} \\
(1.84)\end{array}$ & $\begin{array}{l}4.58^{* *} \\
(1.84)\end{array}$ & $\begin{array}{c}5.75^{* * *} \\
(1.91)\end{array}$ & $\begin{array}{l}4.73^{* *} \\
(1.85)\end{array}$ & $\begin{array}{l}4.43^{* *} \\
(1.85)\end{array}$ \\
\hline Constant & $\begin{array}{c}-9.00 * * * \\
(2.57)\end{array}$ & $\begin{array}{c}-8.63^{* * *} \\
(2.46)\end{array}$ & $\begin{array}{c}-8.69^{* * * *} \\
(2.46)\end{array}$ & $\begin{array}{c}-9.72^{* * *} \\
(2.69)\end{array}$ & $\begin{array}{c}-8.20^{* * *} \\
(2.60)\end{array}$ & $\begin{array}{c}-8.68^{* * *} \\
(2.61)\end{array}$ \\
\hline Observations & 166 & 166 & 166 & 165 & 165 & 165 \\
\hline R-squared & 0.17 & 0.14 & 0.17 & 0.18 & 0.14 & 0.17 \\
\hline
\end{tabular}

Table 19: GDP Per Capita Growth Revisions for 2020 - Relation with Mobility

\begin{tabular}{|c|c|c|c|c|c|c|}
\hline & (1) & $(2)$ & (3) & $(4)$ & $(5)$ & $(6)$ \\
\hline & \multicolumn{6}{|c|}{2020 GDP Growth Per Capita (\%) } \\
\hline & $\begin{array}{l}\text { Actual } \\
2020\end{array}$ & $\begin{array}{c}\text { Change } \\
\text { vs. } 2019\end{array}$ & $\begin{array}{c}\text { Revision } \\
\text { vs. Jan } 2020\end{array}$ & $\begin{array}{l}\text { Actual } \\
2020\end{array}$ & $\begin{array}{l}\text { Change } \\
\text { vs. } 2019\end{array}$ & $\begin{array}{c}\text { Revision } \\
\text { vs. Jan } 2020\end{array}$ \\
\hline Stringency (average) & $\begin{array}{l}-1.63 \\
(1.86)\end{array}$ & $\begin{array}{l}-2.46 \\
(1.70)\end{array}$ & $\begin{array}{l}-3.17^{*} \\
(1.71)\end{array}$ & $\begin{array}{l}-0.18 \\
(2.40)\end{array}$ & $\begin{array}{l}-1.72 \\
(2.13)\end{array}$ & $\begin{array}{l}-1.92 \\
(2.24)\end{array}$ \\
\hline Covid-19 deaths & $\begin{array}{c}-2.14^{* *} \\
(0.97)\end{array}$ & $\begin{array}{c}-2.36^{* * *} \\
(0.89)\end{array}$ & $\begin{array}{c}-1.85^{* *} \\
(0.89)\end{array}$ & & & \\
\hline Google mobility (average) & & & & $\begin{array}{c}1.13^{* * *} \\
(0.42)\end{array}$ & $\begin{array}{l}0.67^{*} \\
(0.37)\end{array}$ & $\begin{array}{l}0.80^{* *} \\
(0.40)\end{array}$ \\
\hline Log GDP per capita & $\begin{array}{l}0.97^{*} \\
(0.57)\end{array}$ & $\begin{array}{c}0.71 \\
(0.52)\end{array}$ & $\begin{array}{l}0.87^{*} \\
(0.52)\end{array}$ & $\begin{array}{l}1.26^{*} \\
(0.66)\end{array}$ & $\begin{array}{l}1.09^{*} \\
(0.59)\end{array}$ & $\begin{array}{l}1.34^{* *} \\
(0.62)\end{array}$ \\
\hline EMDEs & $\begin{array}{l}-0.84 \\
(1.05)\end{array}$ & $\begin{array}{l}-0.49 \\
(0.96)\end{array}$ & $\begin{array}{l}-1.06 \\
(0.96)\end{array}$ & $\begin{array}{l}-0.16 \\
(1.10)\end{array}$ & $\begin{array}{l}-0.05 \\
(0.98)\end{array}$ & $\begin{array}{l}-0.45 \\
(1.03)\end{array}$ \\
\hline LIDCs & $\begin{array}{l}3.72^{*} \\
(1.90)\end{array}$ & $\begin{array}{l}2.60 \\
(1.73)\end{array}$ & $\begin{array}{c}2.76 \\
(1.74)\end{array}$ & $\begin{array}{l}4.67^{* *} \\
(1.99)\end{array}$ & $\begin{array}{l}3.49^{*} \\
(1.77)\end{array}$ & $\begin{array}{l}3.76^{* *} \\
(1.87)\end{array}$ \\
\hline Constant & $\begin{array}{c}-7.27^{* * *} \\
(2.50)\end{array}$ & $\begin{array}{c}-7.20^{* * *} \\
(2.28)\end{array}$ & $\begin{array}{c}-7.55^{* * *} \\
(2.29)\end{array}$ & $\begin{array}{c}-10.41^{* * * *} \\
(3.05)\end{array}$ & $\begin{array}{c}-10.27^{* * * *} \\
(2.71)\end{array}$ & $\begin{array}{c}-11.02^{* * * *} \\
(2.86)\end{array}$ \\
\hline Observations & 154 & 154 & 154 & 126 & 126 & 126 \\
\hline R-squared & 0.18 & 0.17 & 0.19 & 0.23 & 0.18 & 0.22 \\
\hline
\end{tabular}


Table 20: GDP Growth Revisions for 2020 - Relation with Stringency

\begin{tabular}{|c|c|c|c|c|c|c|}
\hline & (1) & $(2)$ & (3) & (4) & (5) & (6) \\
\hline & \multicolumn{6}{|c|}{2020 GDP Growth (\%) } \\
\hline & $\begin{array}{l}\text { Actual } \\
2020\end{array}$ & $\begin{array}{c}\text { Change } \\
\text { vs. } 2019 \\
\end{array}$ & $\begin{array}{c}\text { Revision } \\
\text { vs. Jan } 2020\end{array}$ & $\begin{array}{l}\text { Actual } \\
2020\end{array}$ & $\begin{array}{c}\text { Change } \\
\text { vs. } 2019\end{array}$ & $\begin{array}{c}\text { Revision } \\
\text { vs. Jan } 2020\end{array}$ \\
\hline Containment (average) & $\begin{array}{l}-0.96 \\
(1.95)\end{array}$ & $\begin{array}{l}-2.72 \\
(1.81)\end{array}$ & $\begin{array}{c}-3.54^{* *} \\
(1.77)\end{array}$ & & & \\
\hline Stringency (average) & & & & $\begin{array}{l}-1.58 \\
(1.85)\end{array}$ & $\begin{array}{l}-0.37 \\
(1.71)\end{array}$ & $\begin{array}{l}-1.90 \\
(1.68)\end{array}$ \\
\hline Health policies (average) & & & & $\begin{array}{l}1.71 \\
(2.40)\end{array}$ & $\begin{array}{c}-4.40^{* *} \\
(2.21)\end{array}$ & $\begin{array}{l}-2.62 \\
(2.18)\end{array}$ \\
\hline Log GDP per capita & $\begin{array}{c}0.54 \\
(0.55)\end{array}$ & $\begin{array}{c}0.54 \\
(0.51)\end{array}$ & $\begin{array}{c}0.63 \\
(0.50)\end{array}$ & $\begin{array}{c}0.38 \\
(0.58)\end{array}$ & $\begin{array}{c}0.82 \\
(0.53)\end{array}$ & $\begin{array}{c}0.74 \\
(0.53)\end{array}$ \\
\hline EMDEs & $\begin{array}{l}-0.62 \\
(1.02)\end{array}$ & $\begin{array}{l}-0.55 \\
(0.94)\end{array}$ & $\begin{array}{l}-1.32 \\
(0.92)\end{array}$ & $\begin{array}{l}-0.53 \\
(1.02)\end{array}$ & $\begin{array}{l}-0.80 \\
(0.94)\end{array}$ & $\begin{array}{l}-1.47 \\
(0.93)\end{array}$ \\
\hline LIDCs & $\begin{array}{c}5.06^{* * *} \\
(1.74)\end{array}$ & $\begin{array}{l}3.02^{*} \\
(1.62)\end{array}$ & $\begin{array}{c}2.51 \\
(1.58)\end{array}$ & $\begin{array}{c}4.98^{* * * *} \\
(1.75)\end{array}$ & $\begin{array}{l}3.05^{*} \\
(1.61)\end{array}$ & $\begin{array}{c}2.46 \\
(1.59)\end{array}$ \\
\hline Constant & $\begin{array}{c}-6.74^{* * *} \\
(2.33)\end{array}$ & $\begin{array}{c}-7.71^{* * *} \\
(2.16)\end{array}$ & $\begin{array}{c}-7.39 * * * \\
(2.12)\end{array}$ & $\begin{array}{c}-7.09 * * * \\
(2.46)\end{array}$ & $\begin{array}{c}-6.96^{* * *} \\
(2.27)\end{array}$ & $\begin{array}{c}-6.98^{* * *} \\
(2.24)\end{array}$ \\
\hline Observations & 166 & 166 & 166 & 165 & 165 & 165 \\
\hline R-squared & 0.23 & 0.12 & 0.16 & 0.23 & 0.13 & 0.15 \\
\hline
\end{tabular}

Table 21: GDP Growth Revisions for 2020 - Relation with Mobility

\begin{tabular}{|c|c|c|c|c|c|c|}
\hline & (1) & $(2)$ & $(3)$ & (4) & $(5)$ & (6) \\
\hline & \multicolumn{6}{|c|}{2020 GDP Growth (\%) } \\
\hline & $\begin{array}{l}\text { Actual } \\
2020\end{array}$ & $\begin{array}{c}\text { Change } \\
\text { vs. } 2019\end{array}$ & $\begin{array}{c}\text { Revision } \\
\text { vs. Jan } 2020\end{array}$ & $\begin{array}{l}\text { Actual } \\
2020\end{array}$ & $\begin{array}{c}\text { Change } \\
\text { vs. } 2019\end{array}$ & $\begin{array}{c}\text { Revision } \\
\text { vs. Jan } 2020\end{array}$ \\
\hline Stringency (average) & $\begin{array}{l}-1.16 \\
(1.85)\end{array}$ & $\begin{array}{l}-2.32 \\
(1.68)\end{array}$ & $\begin{array}{c}-3.34^{* *} \\
(1.69)\end{array}$ & $\begin{array}{c}0.12 \\
(2.43)\end{array}$ & $\begin{array}{l}-1.54 \\
(2.10)\end{array}$ & $\begin{array}{l}-1.99 \\
(2.20)\end{array}$ \\
\hline Covid-19 deaths & $\begin{array}{c}-2.77^{* * *} \\
(0.97)\end{array}$ & $\begin{array}{c}-2.32^{* * *} \\
(0.88)\end{array}$ & $\begin{array}{c}-1.81^{* *} \\
(0.88)\end{array}$ & & & \\
\hline Google mobility (average) & & & & $\begin{array}{l}1.09 * * \\
(0.43)\end{array}$ & $\begin{array}{c}0.77^{* *} \\
(0.37)\end{array}$ & $\begin{array}{c}0.87^{* *} \\
(0.39)\end{array}$ \\
\hline Log GDP per capita & $\begin{array}{c}0.66 \\
(0.57)\end{array}$ & $\begin{array}{c}0.57 \\
(0.52)\end{array}$ & $\begin{array}{c}0.73 \\
(0.52)\end{array}$ & $\begin{array}{c}0.90 \\
(0.68)\end{array}$ & $\begin{array}{l}1.07^{*} \\
(0.58)\end{array}$ & $\begin{array}{l}1.15^{*} \\
(0.61)\end{array}$ \\
\hline EMDEs & $\begin{array}{l}-1.05 \\
(1.05)\end{array}$ & $\begin{array}{l}-0.68 \\
(0.95)\end{array}$ & $\begin{array}{l}-1.30 \\
(0.96)\end{array}$ & $\begin{array}{l}-0.24 \\
(1.12)\end{array}$ & $\begin{array}{l}-0.05 \\
(0.97)\end{array}$ & $\begin{array}{l}-0.72 \\
(1.01)\end{array}$ \\
\hline LIDCs & $\begin{array}{l}4.08^{* *} \\
(1.89)\end{array}$ & $\begin{array}{c}2.22 \\
(1.71)\end{array}$ & $\begin{array}{c}2.27 \\
(1.72)\end{array}$ & $\begin{array}{l}5.21^{* *} \\
(2.03)\end{array}$ & $\begin{array}{l}3.37^{*} \\
(1.75)\end{array}$ & $\begin{array}{l}3.12^{*} \\
(1.83)\end{array}$ \\
\hline Constant & $\begin{array}{c}-5.48^{* *} \\
(2.49)\end{array}$ & $\begin{array}{c}-6.92^{* * *} \\
(2.26)\end{array}$ & $\begin{array}{c}-7.03^{* * * *} \\
(2.27)\end{array}$ & $\begin{array}{c}-8.74^{* * *} \\
(3.10)\end{array}$ & $\begin{array}{c}-10.46^{* * *} \\
(2.68)\end{array}$ & $\begin{array}{c}-10.40^{* * *} \\
(2.80)\end{array}$ \\
\hline Observations & 154 & 154 & 154 & 126 & 126 & 126 \\
\hline R-squared & 0.27 & 0.17 & 0.20 & 0.27 & 0.19 & 0.23 \\
\hline
\end{tabular}


Figure 20: Marginal Effect of Death Rates, Conditional on Average Stringency

(a) GDP growth in 2020

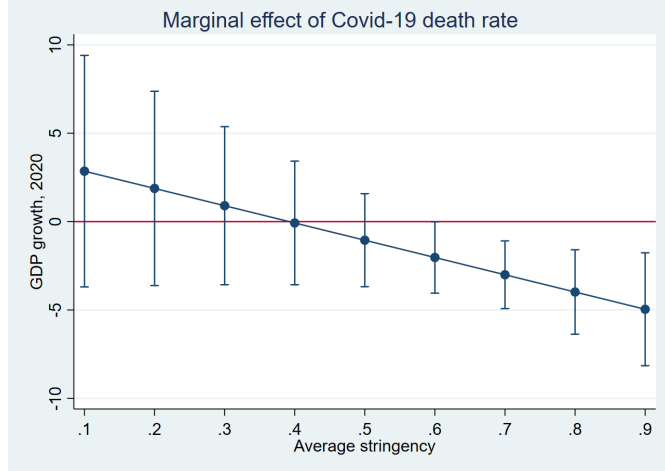

(b) GDP growth in 2020 vs. Jan 2020 WEO

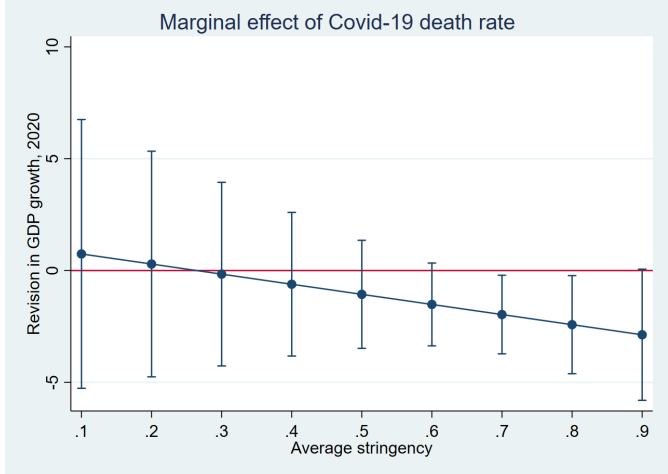

Table 22: Primary Balance Revisions for 2020 - Relation with Stringency

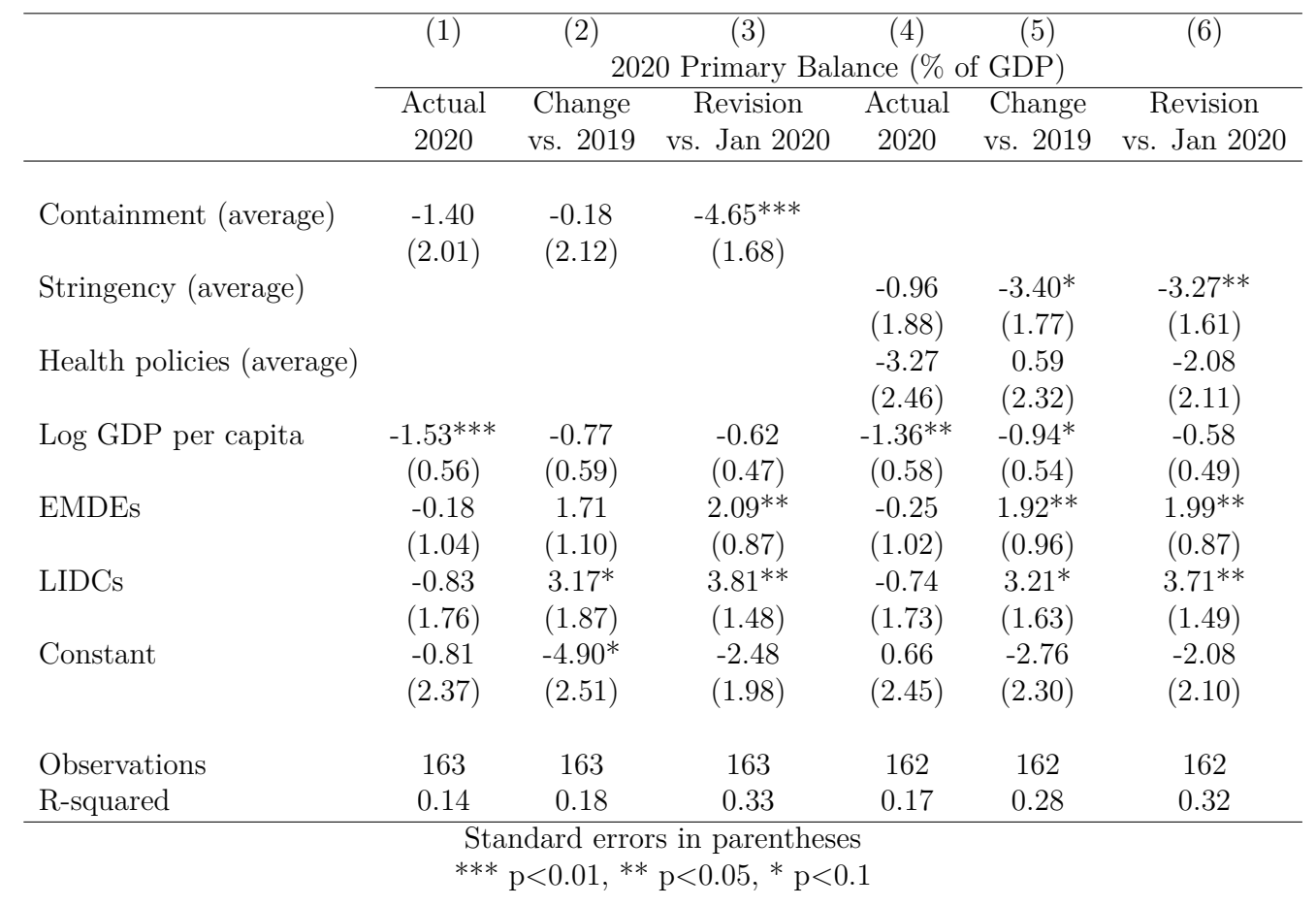


Table 23: Primary Balance Revisions for 2020 - Relation with Mobility

\begin{tabular}{|c|c|c|c|c|c|c|}
\hline & (1) & $(2)$ & $(3)$ & $(4)$ & $(5)$ & (6) \\
\hline & \multicolumn{6}{|c|}{2020 Primary Balance (\% of GDP) } \\
\hline & $\begin{array}{c}\text { Actual } \\
2020 \\
\end{array}$ & $\begin{array}{c}\text { Change } \\
\text { vs. } 2019\end{array}$ & $\begin{array}{c}\text { Revision } \\
\text { vs. Jan } 2020 \\
\end{array}$ & $\begin{array}{c}\text { Actual } \\
2020 \\
\end{array}$ & $\begin{array}{l}\text { Change } \\
\text { vs. } 2019 \\
\end{array}$ & $\begin{array}{c}\text { Revision } \\
\text { vs. Jan } 2020 \\
\end{array}$ \\
\hline Stringency (average) & $\begin{array}{l}-2.29 \\
(1.84)\end{array}$ & $\begin{array}{l}-2.86^{*} \\
(1.59)\end{array}$ & $\begin{array}{l}-2.81^{*} \\
(1.44)\end{array}$ & $\begin{array}{l}-3.35 \\
(2.44)\end{array}$ & $\begin{array}{l}-4.03^{*} \\
(2.08)\end{array}$ & $\begin{array}{l}-3.72^{*} \\
(1.89)\end{array}$ \\
\hline Covid-19 deaths & $\begin{array}{l}-0.20 \\
(0.96)\end{array}$ & $\begin{array}{l}-0.32 \\
(0.84)\end{array}$ & $\begin{array}{l}-0.12 \\
(0.76)\end{array}$ & & & \\
\hline Google mobility (average) & & & & $\begin{array}{c}0.21 \\
(0.43)\end{array}$ & $\begin{array}{l}-0.34 \\
(0.36)\end{array}$ & $\begin{array}{l}-0.16 \\
(0.33)\end{array}$ \\
\hline Log GDP per capita & $\begin{array}{c}-1.36^{* *} \\
(0.56)\end{array}$ & $\begin{array}{c}-1.13^{* *} \\
(0.49)\end{array}$ & $\begin{array}{l}-0.54 \\
(0.44)\end{array}$ & $\begin{array}{c}-1.60^{* *} \\
(0.67)\end{array}$ & $\begin{array}{c}-1.11^{*} \\
(0.57)\end{array}$ & $\begin{array}{l}-0.66 \\
(0.52)\end{array}$ \\
\hline EMDEs & $\begin{array}{l}-0.15 \\
(1.03)\end{array}$ & $\begin{array}{l}1.57^{*} \\
(0.90)\end{array}$ & $\begin{array}{c}1.89^{* *} \\
(0.81)\end{array}$ & $\begin{array}{c}0.67 \\
(1.11)\end{array}$ & $\begin{array}{l}1.88^{* *} \\
(0.94)\end{array}$ & $\begin{array}{c}2.04^{* *} \\
(0.86)\end{array}$ \\
\hline LIDCs & $\begin{array}{l}-0.18 \\
(1.85)\end{array}$ & $\begin{array}{c}2.10 \\
(1.61)\end{array}$ & $\begin{array}{c}3.74^{* *} \\
(1.45)\end{array}$ & $\begin{array}{l}-0.67 \\
(2.01)\end{array}$ & $\begin{array}{c}2.50 \\
(1.71)\end{array}$ & $\begin{array}{c}3.80^{* *} \\
(1.56)\end{array}$ \\
\hline Constant & $\begin{array}{l}-0.68 \\
(2.45)\end{array}$ & $\begin{array}{l}-1.69 \\
(2.13)\end{array}$ & $\begin{array}{c}-3.85^{* *} \\
(1.92)\end{array}$ & $\begin{array}{c}0.25 \\
(3.08)\end{array}$ & $\begin{array}{l}-1.47 \\
(2.62)\end{array}$ & $\begin{array}{l}-3.21 \\
(2.39)\end{array}$ \\
\hline Observations & 152 & 152 & 152 & 124 & 124 & 124 \\
\hline R-squared & 0.18 & 0.31 & 0.34 & 0.17 & 0.30 & 0.34 \\
\hline
\end{tabular}

Table 24: Primary Balance Revisions for 2020 - Relation with Fiscal Packages

\begin{tabular}{|c|c|c|c|c|c|c|}
\hline & (1) & $(2)$ & (3) & $(4)$ & (5) & (6) \\
\hline & \multicolumn{6}{|c|}{2020 Primary Balance (\% of GDP) } \\
\hline & $\begin{array}{l}\text { Actual } \\
2020\end{array}$ & $\begin{array}{c}\text { Change } \\
\text { vs. } 2019 \\
\end{array}$ & $\begin{array}{c}\text { Revision } \\
\text { vs. Jan } 2020 \\
\end{array}$ & $\begin{array}{c}\text { Actual } \\
2020\end{array}$ & $\begin{array}{c}\text { Change } \\
\text { vs. } 2019 \\
\end{array}$ & $\begin{array}{c}\text { Revision } \\
\text { vs. Jan } 2020\end{array}$ \\
\hline Stringency (average) & $\begin{array}{l}-1.27 \\
(1.80)\end{array}$ & $\begin{array}{l}-1.16 \\
(2.05)\end{array}$ & $\begin{array}{c}-3.61^{* *} \\
(1.62)\end{array}$ & $\begin{array}{l}-1.94 \\
(1.93)\end{array}$ & $\begin{array}{l}-2.71 \\
(1.71)\end{array}$ & $\begin{array}{l}-1.89 \\
(1.46)\end{array}$ \\
\hline Covid-19 fiscal support in 2020 & $\begin{array}{c}-0.57^{* * *} \\
(0.11)\end{array}$ & $\begin{array}{c}-0.31^{* *} \\
(0.13)\end{array}$ & $\begin{array}{l}-0.17 \\
(0.10)\end{array}$ & $\begin{array}{c}-0.43^{* * *} \\
(0.13)\end{array}$ & $\begin{array}{c}-0.27^{* *} \\
(0.11)\end{array}$ & $\begin{array}{c}-0.43^{* * *} \\
(0.10)\end{array}$ \\
\hline Covid-19 deaths & & & & $\begin{array}{l}-0.12 \\
(0.97)\end{array}$ & $\begin{array}{l}-0.67 \\
(0.86)\end{array}$ & $\begin{array}{l}-0.20 \\
(0.74)\end{array}$ \\
\hline Log GDP per capita & $\begin{array}{c}-1.61^{* * *} \\
(0.53)\end{array}$ & $\begin{array}{l}-0.79 \\
(0.60)\end{array}$ & $\begin{array}{l}-0.83^{*} \\
(0.48)\end{array}$ & $\begin{array}{l}-1.34^{* *} \\
(0.55)\end{array}$ & $\begin{array}{c}-1.16^{* *} \\
(0.49)\end{array}$ & $\begin{array}{l}-0.63 \\
(0.42)\end{array}$ \\
\hline EMDEs & $\begin{array}{l}-1.59 \\
(1.04)\end{array}$ & $\begin{array}{c}1.20 \\
(1.18)\end{array}$ & $\begin{array}{l}1.73^{*} \\
(0.93)\end{array}$ & $\begin{array}{l}-1.02 \\
(1.07)\end{array}$ & $\begin{array}{c}0.99 \\
(0.95)\end{array}$ & $\begin{array}{c}0.85 \\
(0.81)\end{array}$ \\
\hline LIDCs & $\begin{array}{l}-2.44 \\
(1.73)\end{array}$ & $\begin{array}{c}2.46 \\
(1.96)\end{array}$ & $\begin{array}{l}3.17^{* *} \\
(1.56)\end{array}$ & $\begin{array}{l}-1.04 \\
(1.84)\end{array}$ & $\begin{array}{c}1.28 \\
(1.63)\end{array}$ & $\begin{array}{l}2.44^{*} \\
(1.40)\end{array}$ \\
\hline Constant & $\begin{array}{c}2.57 \\
(2.43)\end{array}$ & $\begin{array}{l}-2.64 \\
(2.75)\end{array}$ & $\begin{array}{l}-1.70 \\
(2.19)\end{array}$ & $\begin{array}{c}1.22 \\
(2.52)\end{array}$ & $\begin{array}{l}-0.11 \\
(2.23)\end{array}$ & $\begin{array}{l}-1.87 \\
(1.91)\end{array}$ \\
\hline Observations & 155 & 155 & 155 & 146 & 146 & 146 \\
\hline R-squared & 0.27 & 0.22 & 0.35 & 0.25 & 0.36 & 0.44 \\
\hline
\end{tabular}


Table 25: Covid-19 Fiscal Support Packages - Relation with Stringency

\begin{tabular}{|c|c|c|c|c|c|c|}
\hline \multirow[b]{4}{*}{ FM Edition } & (1) & $(2)$ & $(3)$ & \multirow{2}{*}{\multicolumn{2}{|c|}{$\begin{array}{c}(4) \quad(5) \\
\text { iscal Support (\% of GDP) }\end{array}$}} & \multirow[t]{2}{*}{ (6) } \\
\hline & \multirow{2}{*}{\multicolumn{6}{|c|}{\begin{tabular}{cccc}
\multicolumn{4}{c}{ Covid-19 Above-the-line Fiscal Support (\% of GDP) } \\
Support in 2020 & Total support & Support in 2020 & Total support
\end{tabular}}} \\
\hline & & & & & & \\
\hline & $\begin{array}{l}\text { Support in } 2020 \\
\text { Jan } 2021\end{array}$ & Jan 2021 & Oct 2020 & $\begin{array}{l}\text { Jan } 2021 \\
\end{array}$ & \multicolumn{2}{|c|}{ Ionda suppote } \\
\hline Stringency (average) & $\begin{array}{l}-1.11 \\
(1.34)\end{array}$ & $\begin{array}{l}-0.10 \\
(1.65)\end{array}$ & $\begin{array}{l}-1.06 \\
(1.25)\end{array}$ & $\begin{array}{c}-1.91 \\
(1.41)\end{array}$ & $\begin{array}{l}-0.95 \\
(1.74)\end{array}$ & $\begin{array}{l}-1.03 \\
(1.33)\end{array}$ \\
\hline Stringency (average) x AE dummy & & & & $\begin{array}{l}7.37^{*} \\
(4.27)\end{array}$ & $\begin{array}{c}7.91 \\
(5.30)\end{array}$ & $\begin{array}{l}-0.24 \\
(4.03)\end{array}$ \\
\hline Log GDP per capita & $\begin{array}{c}0.05 \\
(0.40)\end{array}$ & $\begin{array}{l}-0.18 \\
(0.49)\end{array}$ & $\begin{array}{c}0.14 \\
(0.37)\end{array}$ & $\begin{array}{c}0.07 \\
(0.39)\end{array}$ & $\begin{array}{l}-0.16 \\
(0.49)\end{array}$ & $\begin{array}{c}0.14 \\
(0.37)\end{array}$ \\
\hline EMDEs & $\begin{array}{c}-2.85^{* * *} \\
(0.74)\end{array}$ & $\begin{array}{c}-4.87^{* * *} \\
(0.92)\end{array}$ & $\begin{array}{c}-3.43^{* * *} \\
(0.69)\end{array}$ & $\begin{array}{l}1.70 \\
(2.74)\end{array}$ & $\begin{array}{c}0.02 \\
(3.40)\end{array}$ & $\begin{array}{l}-3.58 \\
(2.58)\end{array}$ \\
\hline LIDCs & $\begin{array}{c}-3.10^{* *} \\
(1.26)\end{array}$ & $\begin{array}{c}-5.22^{* * *} \\
(1.57)\end{array}$ & $\begin{array}{c}-3.93^{* * *} \\
(1.18)\end{array}$ & $\begin{array}{c}1.36 \\
(2.87)\end{array}$ & $\begin{array}{l}-0.44 \\
(3.56)\end{array}$ & $\begin{array}{l}-4.08 \\
(2.71)\end{array}$ \\
\hline Constant & $\begin{array}{c}6.62^{* * *} \\
(1.72)\end{array}$ & $\begin{array}{c}8.69^{* * * *} \\
(2.12)\end{array}$ & $\begin{array}{c}6.83^{* * *} \\
(1.60)\end{array}$ & $\begin{array}{c}2.60 \\
(2.89)\end{array}$ & $\begin{array}{c}4.36 \\
(3.59)\end{array}$ & $\begin{array}{l}6.97^{* *} \\
(2.72)\end{array}$ \\
\hline Observations & 157 & 157 & 156 & 157 & 157 & 156 \\
\hline R-squared & 0.18 & 0.24 & 0.29 & 0.19 & 0.25 & 0.29 \\
\hline
\end{tabular}

Table 26: Covid-19 Fiscal Support Packages - Relation with Mobility

\begin{tabular}{|c|c|c|c|c|c|c|}
\hline \multirow[b]{4}{*}{ FM Edition } & (1) & $(2)$ & $(3)$ & $(4)$ & $(5)$ & $(6)$ \\
\hline & \multicolumn{6}{|c|}{ Covid-19 Above-the-line Fiscal Support (\% of GDP) } \\
\hline & \multirow{2}{*}{$\begin{array}{c}\text { Support in } 2020 \\
\text { Jan } 2021\end{array}$} & \multicolumn{2}{|c|}{ Total support } & \multirow{2}{*}{$\begin{array}{c}\text { Support in } 2020 \\
\text { Jan } 2021\end{array}$} & \multicolumn{2}{|c|}{ Total support } \\
\hline & & Jan 2021 & Oct 2020 & & Jan 2021 & Oct 2020 \\
\hline \multirow[t]{2}{*}{ Stringency (average) } & 0.25 & 1.00 & -0.02 & 0.16 & 0.06 & -0.03 \\
\hline & $(1.33)$ & $(1.80)$ & $(1.35)$ & $(1.62)$ & $(2.09)$ & $(1.77)$ \\
\hline \multirow[t]{2}{*}{ Covid-19 deaths (average) } & 0.52 & 0.21 & 0.14 & & & \\
\hline & $(0.67)$ & $(0.91)$ & $(0.68)$ & & & \\
\hline \multirow[t]{2}{*}{ Google mobility (average) } & & & & -0.20 & -0.24 & -0.06 \\
\hline & & & & $(0.27)$ & $(0.35)$ & $(0.29)$ \\
\hline \multirow[t]{2}{*}{ Log GDP per capita } & 0.07 & -0.19 & 0.28 & 0.23 & 0.04 & -0.01 \\
\hline & $(0.38)$ & $(0.52)$ & $(0.38)$ & $(0.43)$ & $(0.55)$ & $(0.46)$ \\
\hline \multirow[t]{2}{*}{ EMDEs } & $-2.75 * * *$ & $-4.89 * * *$ & $-3.49^{* * *}$ & $-2.97 * * *$ & $-4.90 * * *$ & $-3.87^{* * *}$ \\
\hline & $(0.70)$ & $(0.96)$ & $(0.71)$ & $(0.71)$ & $(0.92)$ & $(0.77)$ \\
\hline \multirow[t]{2}{*}{ LIDCs } & $-2.91^{* *}$ & $-5.25 * * *$ & $-3.62^{* * *}$ & $-3.52^{* * *}$ & $-5.68 * * *$ & $-4.80 * * *$ \\
\hline & $(1.24)$ & $(1.70)$ & $(1.26)$ & $(1.27)$ & $(1.64)$ & $(1.39)$ \\
\hline \multirow{2}{*}{ Constant } & $5.28^{* * *}$ & $7.84^{* * *}$ & $5.68 * * *$ & $5.31^{* * *}$ & $7.99 * * *$ & $6.93^{* * *}$ \\
\hline & $(1.67)$ & $(2.27)$ & $(1.69)$ & $(1.99)$ & $(2.56)$ & $(2.17)$ \\
\hline Observations & 146 & 146 & 145 & 120 & 121 & 120 \\
\hline R-squared & 0.22 & 0.25 & 0.32 & 0.32 & 0.37 & 0.35 \\
\hline
\end{tabular}

